\title{
Unfulfilled Promises: Women's Rights in Egypt
}

Nemat Guenena

Nadia Wassef

Follow this and additional works at: https://knowledgecommons.popcouncil.org/departments_sbsr-pgy How does access to this work benefit you? Let us know!

\section{Recommended Citation}

Guenena, Nemat and Nadia Wassef. 1999. "Unfulfilled Promises: Women's Rights in Egypt." Cairo: Population Council. 


\section{2 $9 \log 9$ \%}

\section{Unifuilfillled Promises}

Women's Rights In Egypt

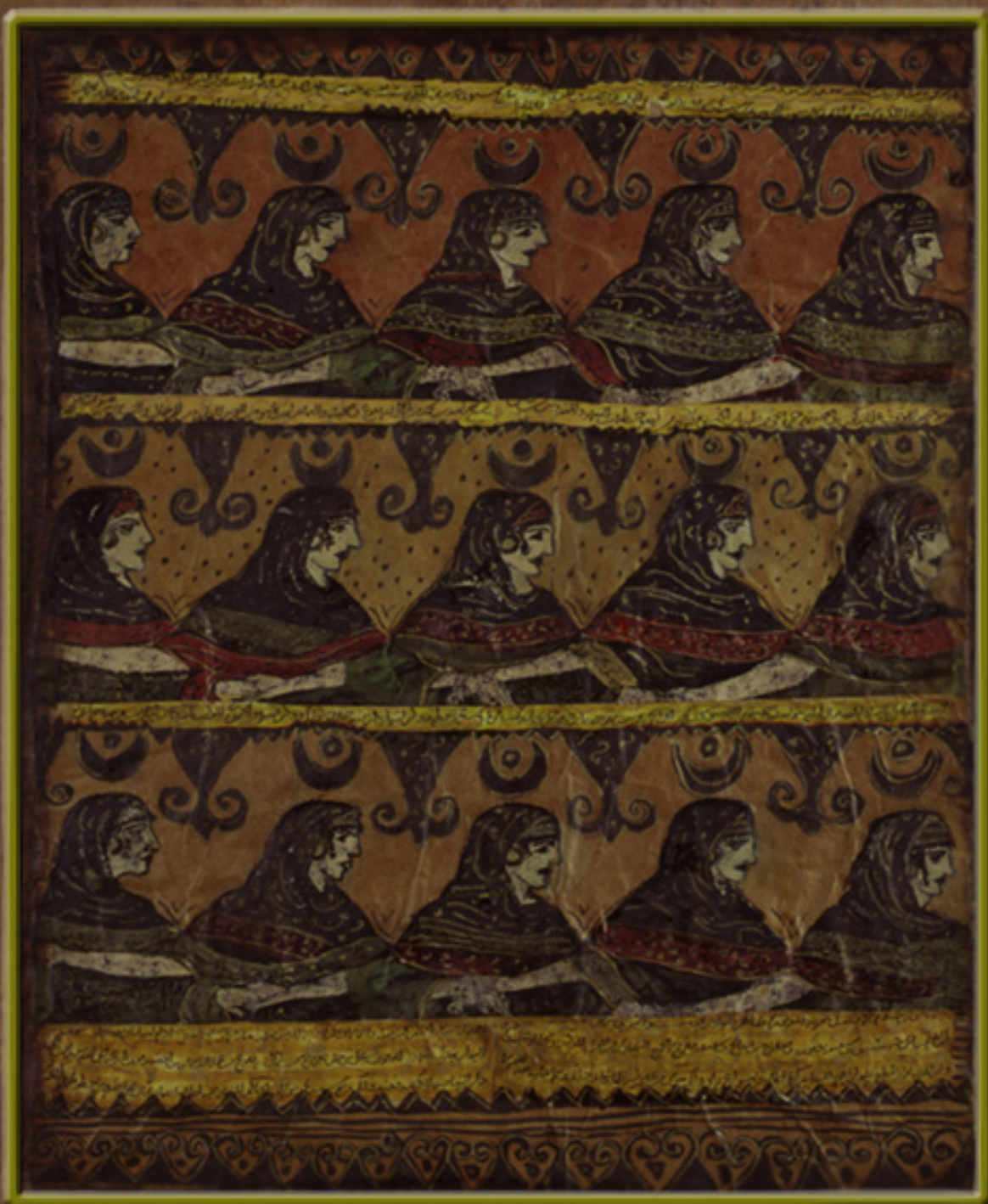

Nemat Guenena Nadia Wassef

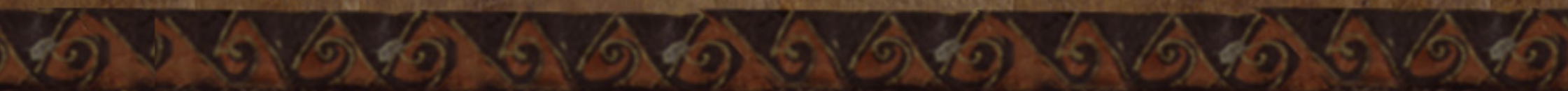




\section{Unfulfilled Promises: Women's Rights}

Nemat Guenena and Nadia Wassef ${ }^{*}$ 


\section{ACKNOWLEDGMENTS}

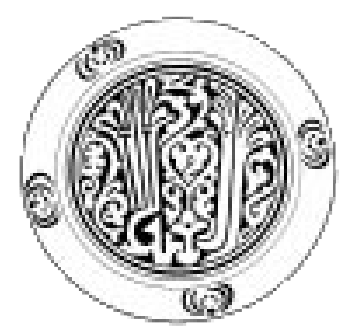

The authors would like to thank all those who contributed to the production of this monograph in its final shape. Asef Bayat, Huda Elsadda, Barbara Ibrahim, Mounir Neamatalla, Cynthia Nelson, Shahnaz Rouse, Aida Seif al-Dawla, and Hania Sholkamy were our first readers; we thank them for the time they took in reading the first draft of this work and providing us with constructive comments. We would also like to express our heartfelt thanks to Leila Hessini for her role as both a supportive friend and an astute reader. Thanks are also owed to Barbara Ibrahim and Moushira El-Geziri from the Population Council for their support and patience. This monograph would not have come out in its final shape without their support, patience, and advice. We are very grateful to Jan Amin for her thoughtful suggestions. We are also greatly indebted to Susan Lee for seeing us through the last stage of the project.

We would also like to express our gratitude to Huda Lutfi for offering one of her paintings as a cover for this monograph. We are also indebted to the New Woman Research Center for permitting us to select some photographs from their photo archive for this publication, and to the organizations who gave us their posters. Finally, we owe a great debt to the individuals who were interviewed and shared insights about their organizations with us, and who offered us their unconditional support. Ultimately, we hope that this work will benefit NGOs and activists and will make a contribution to the literature on women's issues in Egypt. 


\section{About the Authors}

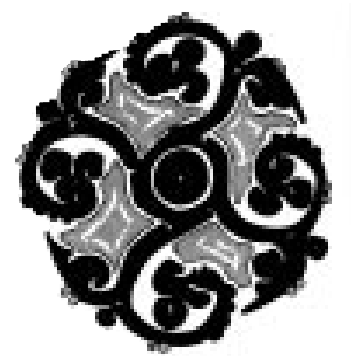

Nemat Guenena is director of the Socioeconomic Research Unit at Environmental Quality International (EQI) and associate researcher at the Ibn Khaldoun Center for Development Studies. Over the years she has been involved in research on developmental issues and social movements, with special emphasis on Islamic movements in Egypt.

Nadia Wassef is an independent researcher on gender issues. She is a member of several nongovernmental organizations (NGOs): the New Woman Research Centre, the Female Genital Mutilation (FGM) Task Force, and the Women and Memory Forum. She has done research on the history of women's movements in Egypt and FGM from a variety of angles. She is currently involved in a study on constructions of masculinities in the Arab world. 


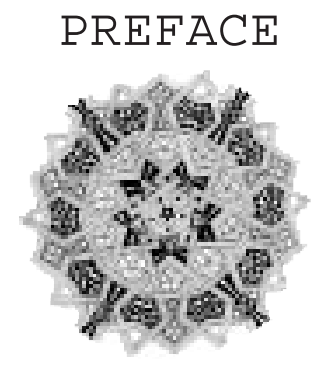

This is a century marked by tremendous change in women's place in society. In Egypt, moves to integrate women more fully into all aspects of public life have been protracted and often accompanied by controversy. Yet, surprisingly little attention has been given to the public discourse around gender and women's place in society. As a result, sterotypes abound. Simplistic dichotomies between the forces advocating religious conservatism versus those championing secular liberalism, for example, mask a more complex reality. The authors of this monograph argue that major political forces today have appropriated the "woman" issue as a basis for building popular legitimacy. They trace the origins and development of these trends and speculate on some of the important consequences for Egyptian women's lives.

The genesis of this project was a dialogue among women from many African countries over the nature of "women in crisis". North African women expressed the view that the situation in their part of the continent was sometimes overlooked because it rarely took the dramatic form of wars or natural disasters. Nonetheless, women in those societies felt an encroachment on their public 'space' and a sense of building tension around the politics of gender.

In 1997, a group of scholars affiliated with the Population Council regional office in Cairo decided to undertake studies on the nature of these public struggles. They ultimately selected Algeria and Egypt as two important cases for fuller analysis. From the beginning, an effort was made to include multiple perspectives and disciplines. Leila Hesseini, an anthropologist, was the principal author of two monographs on the sitation in Algeria. She was assisted by several women in Algeria who, for reasons of security, requested anonymity.

In Egypt, the team was made up of Nemat Guenena, a sociologist who writes on Islamic movments, and Nadia Wassef, a writer/ activist whose work has focused on feminism and gender issues. In the volume they jointly produced here, each had a unique perspective and responsibility. Nemat Guenena developed a section on the recent history of religious and political discourse. She also reviews women's contemporary status in Egypt, providing examples of how the public discourse impacts women's concerns and opportunities. Nadia Wassef developed sections dealing with the context of feminism and activism in Egypt. She examines the historical struggle for women's rights, uncovering patterns of continuity and change. Nadia also looks at local women's rights organizations and the strategies of resistance they promote.

The monograph was developed ove a two-year period of intense research, debate, and revision. We are grateful to a number of perceptive readers who contributed to sharpening the ideas presented here. It is the hope of the Population Council that this publication will stimulate further dialogue over these issues in Egypt. As a momentous century for gender relations everywhere comes to a close, it is an appropriate moment to reflect on the future of women and men in one of the world's oldest civilizations. 


\section{TABLE OF CONTENTS}

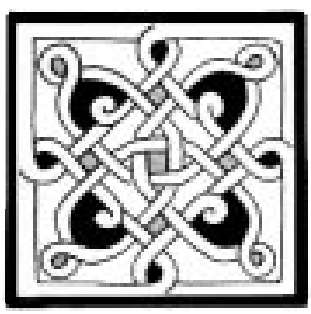

\section{Introduction}
A. Definitions
B. The Islamic Movement in Egypt

\section{A Century of Struggle}
A. Forging a Feminist Consciousness
1. Aisha Al-Taymouriya: A Blocked Writer
2. Malak Hifni Nassef: A Seeker in the Desert
B. Redefinitions: The Private and Public Spheres
1. The Seclusion of the Harem
2. Segregation and Veiling
C. Moving Into the Public Sphere and its Repercussions
1. Woman's Words, Woman's Absence
2. Feminist Demands, Nationalist Deeds
3. Prison
D. Articulating Feminist Demands
1. Public Voice, Public Persona
E. Redefinitions of Women and the Family: Personal Status Law
1. Polygamy
2. Divorce and Custody
3. Bayt al-Ta'ah
4. Minimum Marriage Age
F. Forging a Public Existence
1. Education
2. Work
3. The Vote

\section{Egyptian Women Today}
A. Women and Education
B. Women and the Media
C. Women and Work
D. Women and Political Participation
E. Women and the Law
F. Women and Health 
IV. The Public Discourse in Egypt
A. Women: Different But Equally Worthy
B. The Personal Status Law and the New Marriage Contract
C. Islamic Attire and the New Veil
D. The International Conference on Population and Development

\section{Strategies of Resistance}
A. Women's Organizations
1. Women and Memory Forum: Knowledge is Power
2. Nour: Arab Women's Publishing House
3. Association for the Development and Empowerment of Women (ADEW): "Give Me Credit for Being a Woman".
4. New Woman Research Centre: Markaz Dirassat al-Mar'ah al-Gedida
5. Centre for Egyptian Women's Legal Assistance: Markaz Qadaya al-Mar'ah al- Misriya
6. The Egyptian Female Genital Mutilation Task Force
B. Self-Esteem Project: "I am proud to be a woman!"
C. Planning Ahead
1. Capacity Building
2. Reaching Out
3. Men's Roles

\section{Conclusion}

VII. Bibliography 


\section{INTRODUCTION}

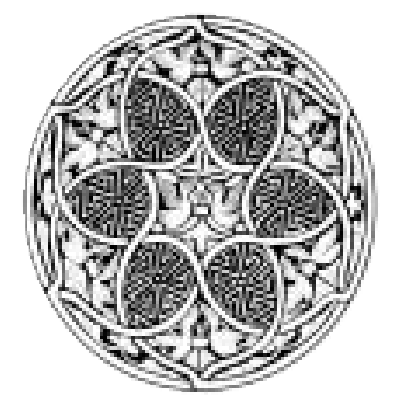

At the turn of the century, Egyptian feminists and women's rights activists struggled for a more equitable status in society. Today, there is almost no field into which Egyptian women have not ventured, yet their status in society remains unequal to that of men. And while there are many factors that account for the prevailing gender gap, male-dominated institutions have continued to relegate women's concerns to a low priority, impeding their progress. In this monograph we contend that recent public discourse in Egypt is dominated by the conservative polemics of the Islamists and that the state, in its attempt to contain the Islamists, has subordinated women's issues to its own concerns for security and legitimacy. Progress toward gender equity is compromised by the state's ambivalent commitment to the cause of women and by the growing influence of the Islamists. Renewed appeals urging women to retreat to the private sphere and the appearance of the Islamic attire (al-ziy al-Islami) reflect the blurring of boundaries between the 'secular' and the 'religious.' We argue that this threatens to negate many of the gains acquired by Egyptian women throughout the past century.

Before proceeding further, we will provide a brief review of the main concepts and terminology used throughout this monograph. This is followed by a background on the history of the Islamic movement in Egypt and a rich overview of Egyptian women in contemporary history. The present condition of Egyptian women is then summarized as a prelude to illustrating, through an examination of the public discourse, how women's issues have been and continue to be relegated to a subordinate position for political expediency. Finally, the concluding chapter presents the strategies of resistance that a number of civil society organizations are adopting to create alternative discourses that give women their rightful positions in both the private and public spheres.

\section{A. DEFINITIONS}

Central to the discourse on gender is the concept of equity (takafu'). ${ }^{1}$ Advanced by scholars of women in development (WID) in the 1970s and early 1980s, it meant equal opportunity for equal contribution. The emphasis on women as agents of production within this view constituted a challenge to the sex role dichotomy that denied women's instrumentality and therefore their due share in the production process. This market-focused equation and the Western-led development model upon which the WID argument was based came under attack on the basis that it ignored or devalued other considerations related to the social significance of biologically-derived activities, class relations, and the international order. Marxist perspectives, while also found lacking because they

Takafu' differs from the term mussawah (equality) as it incorporates the notion of merit. 
have failed to adequately explain the dynamics of the interaction between genders, nevertheless introduced class relations into their analysis of social reality. Accordingly, women's marginalization was perceived as part of a broader system of inequalities created by capitalism. Building on the contributions of both WID and Marxist scholars, a more balanced framework was formulated, integrating gender interests with structural forces. Premising that gender relations determine how individuals experience structural forces, the social relations approach draws attention to the complex, diverse, and often subtle underpinnings of gender inequity. ${ }^{2}$

In this monograph, we contend that any pattern of relations or arrangements that subordinates one gender's concerns to the interests of the other is to be considered unfair, especially if it causes suffering or is likely to result in hardship for the subordinate gender. Furthermore, we argue that the notions of biological distinctiveness and complementarity contained in the Islamic discourse(s) have been used to justify discrimination against Egyptian women in the past; and that they are being used increasingly to this end (refer to chapters II and III, A Century of Struggle and Egyptian Women Today).

Public Discourse is a nebulous concept because it implies the existence of a unified ideology or world view. While there are many discourses that exist at any given moment, each society has a dominant ideological trend that permeates all aspects of life, bearing on social practices and power relations. In Egypt, the past three decades have witnessed the growing influence of Islam as a dominating ideology, challenging both the state and government institutions. This does not mean, however, that the Islamic discourse(s) and the state discourse(s) are entirely or always pitted against each other. History reveals instances and issues of consensus. Moreover, 'the State' is not a static entity; its position vis ₹ vis gender equity has shifted considerably over the past twenty years. We argue, in fact, that there is considerable agreement among Islamists and state officials around women's status and related concerns. Finally, we maintain that political expediency has usually been behind the instances when women have been treated on a more equal footing with men. These issues will be discussed further in chapters II and IV, A Century of Struggle and The Public Discourse in Egypt.

Islamic Activism is the engagement in behavior aimed at the reinstatement of Islamic rule, including Islamic law (Sharia). The terms 'Islamic activists' or 'Islamists' have been used in the literature about Egypt's Islamic movements as umbrella terms describing the militant (violent) wing of the Islamic movement. However, they have also been used to refer to non-violent advocates of an Islamic order, thereby differentiating them from the more individually-oriented Suffis (mystics) who practice their religion and rituals without attempting to effect societal change. ${ }^{3}$ In this monograph we use the terms Islamic activism and Islamism to refer generally to all proponents of an Islamic social alternative in Egypt.

Bringing about Islamic rule is a goal to which all Islamists aspire, even while differing on the modalities and mechanisms of implementation. While for the majority, the Islamic state and society is to be reinstated through advocacy and proselytization, for some it entails a violent struggle against all detractors of the Islamic alternative. Moreover, Islamic activism entails a commitment to bringing to practice the precepts, norms, and codes of behavior ascribed to Islam. ${ }^{4}$ Women and

For a discussion of the theories and concepts shaping the discourse on gender, refer to Kabeer, 1994.

An excellent description of the trends within Egypt's Islamic movement is provided by Shamir, 1992: 41-45.

Abdel Nasser, 1994. 
gender issues are at the core of these, defining the Islamic way of life, and distancing Islamic values and norms from the West or from Western-emulated ways. Consequently, women and their bodies become the repository for tradition and Islamic virtue.

Secularism is used in this monograph for lack of a better term to refer to a trend opposing the permeation of religion in all aspects of social and political life. The Egyptian Constitution combines both civil and religious law. Family and/or personal status issues are governed by Islamic law (Sharia), while the law pertaining to civil matters is based on the French Napoleonic code. Nevertheless, the overriding stipulation in the Constitution is that legislation should not contradict Sharia. Moreover, the Constitution specifies that Islam is the state religion. ${ }^{5}$ Consequently, usage of the term secular to describe the Egyptian state is somewhat misleading, as it implies a non-religious orientation that has never really existed. In the political culture of Egypt, there has never been a separation between state and religion. In fact, the Egyptian state has always maintained a balance, albeit precarious at times, between the requirements of managing a modern nation-state and its commitment to Islam.

Feminism and Women's Rights Activism: Our understanding of 'feminism' (nasawiya) is based on the Egyptian experience. It is "an individual or collective awareness that women have been and continue to be oppressed in diverse ways for diverse reasons." ${ }^{\prime 6}$ Based upon that awareness, Egyptian feminists and women's rights activists work toward liberation from this oppression to promote equitable relations between men and women. The overall goal is a society in which gender equity is a reality within the family, before the law, in political participation, in the work place, in education, and in access to services. We define most of the women in the chapter entitled $A$ Century of Struggle as feminists, while those in Strategies of Resistance are referred to as 'women's rights activists.' This shift in terminology is justified in our view, because changes in contexts and concepts have occurred that allow for this distinction. Ultimately the recognition of women's oppression is shared by feminists and activists, even if the reasons behind that oppression are perceived differently.

Women's rights organizations and activists have gained some prominence in the last two decades. The diversity in their approaches to women's issues is reflected in the wide variety of their activities. The chapter entitled Strategies of Resistance, labels them as activists in the sense that they are, or have been, involved through both words and actions in the creation and articulation of new discourses about women. They are fundamentally motivated by the desire to "improve women's legal, social, political, and economic awareness and position ${ }^{\prime 7}$ through various initiatives and models of action.

Earlier feminists were mainly involved in, but not limited to, advocacy for women's rights and service provision. They started their activities from a mindset of social work and charity. Today under the broad label of women's rights activists, there are those who, like the early feminists, focus on service provision and advocacy. In addition, however, there are those who work on consciousness-raising, grassroots mobilization, and scholarship. The reality of women's lives has

In her chapter on the evolution of the personal status law in Egypt, Talhami (1996: 102-107) also provides an excellent summary of the development of the legal system in Egypt.

Karam, 1998: 5.

Ibid: 4 . 
influenced their demands, which have increased over the decades. This changing reality has brought a new language and new approaches to women's issues-'development' being one of them. These different directions do not have set boundaries dividing them. Under the development project there is room for interaction and the evolution of different models and approaches.

Early in this century, women involved in the Egyptian Feminist Union (EFU) and its offshoots freely labeled themselves as "feminists." After the 1952 revolution, and especially from the 1960s onwards, certain negative connotations were attached to this identity. This has influenced women's rejection of the term today. Nadje al-Ali has recently undertaken research on women's activism in Egypt and explains the situation as follows:

My use of the term 'women's activism' rather than 'feminism' is related to the fact that many of the women I interviewed reject the label 'feminist' for pragmatic and ideological reasons. The English term 'feminist' evokes antagonism and animosity, and sometimes even anxiety, among a great number of women activists, who seem to have internalized the way feminists are being portrayed in prevailing Egyptian discourses: men-hating, aggressive, possibly lesbian (but most likely to be obsessed with sex), and certainly [W] esternized women. The resistance of many Egyptian women to identifying themselves with feminism is not only related to its negative image in society, but is also linked to the conviction that it detracts from such 'larger issues' as imperialism, class struggle, and Zionism. ${ }^{8}$

The desire to highlight other "larger issues" has sometimes meant coopting feminists' demands under a larger umbrella and not always addressing them effectively. The chapter A Century of Struggle contains examples of setbacks women have faced by being co-opted under nationalist, liberal progressive, and socialist discourses.

Feminism, both as a concept (focusing on women and their rights) and as a term, has been, and continues to be, attacked as a Western import. Today women's issues are seen as secondary to larger issues, such as illiteracy and the alleviation of poverty, that are national problems. The assumption made by some critics is that once these problems are solved, women's status will improve. Women's rights activists focusing on women's issues are thus on the margins. Some human nights activists see the issue from the perspective of social justice and reject a purely woman-oriented framework.

There is another dimension to this debate. In an article entitled "Western Feminism Is Not What We Need," written prior to the 1995 United Nations Fourth World Conference on Women, Heba Raouf, editor of the women's page in the Islamist bi-weekly newspaper al-Shaab, states:

...we believe that participation in this conference [the UN Conference on Women] will only deepen Egyptian feminism's financial and ideological dependence on the West. I do not attempt to reconcile Islam and feminism. There cannot be a Muslim feminist, there is only Islam. Hence, I am a Muslim woman who uses traditional Islamic methodology to find out about women's status within religion. ${ }^{9}$ 
In the public discourse, feminism, or women's rights activism, and religion are pitted against each other with little room for negotiation or compromise. There are activists who do not want to operate within a religious framework as well as women who do so exclusively. The former are usually respectful of religion but chose not to preach a vision of women's emancipation through religion.

Raouf's point of view has its adherents, as does the less religiously-oriented feminist or women's rights activist position. We hesitate, however, to refer to 'secular' feminists or activists for several reasons. First, in Egypt the word secular has come to have negative connotations. The term goes beyond the idea of separating religion and the state and has become linked to apostasy, making its use very misleading. Second, in reaching out to people and communities, feminists or activists who would like to operate within a secular framework cannot do so because they would be ignored. A secular approach is not widely shared or appreciated by the society at large. Thus if one hopes to open a dialogue with people, identifying oneself as a secular feminist or activist is a poor entry point. Terms have become highly politicized, causing people to reject some in favor of others that are as yet less loaded and less controversial. The developmental framework offers new labels, but even these are rapidly becoming politicized and problematic.

\section{B. THE ISLAMIC MOVEMENT IN EGYPT}

Activists who raise religious banners in their quest for power do not represent a new phenomenon in contemporary Arab history. However, the potency of the religious alternative and its impact on many spheres, including that of women, has varied over time. In the Arab world, the Islamic banner has been raised in defense of the community of believers (Umma) since the end of the first hijra century (8th century). The rise and fall of the ruling dynasties in the Islamic world was tied to reform-oriented and radical Islamic movements. The Abbassids and Fatimids early on, and the Wahabis, the Mahdists, and the Sanussis in the 18th and 19th centuries, are good examples.

In Egypt, the role of religion as an idiom of discontent has been a constant, resulting in the assassination of Prime Ministers Boutros Boutros Ghali in 1910, Ahmed Maher in 1944, Mahmoud El-Nokrashy in 1949, and President Anwar Sadat in 1981. Islamic activism therefore, is not novel to the Egyptian political scene, yet the situation of some of its current representatives is perceived to be more extreme than that of their predecessors.

These groups are not new to the political scene, except, perhaps that their situation now is more transparently desperate, and they have emerged onto a new political conjuncture of repeated failures of leaders and ideologies, and, crucially of the triumph of the Islamic revolution in Iran. ${ }^{10}$

The early roots of contemporary Islamic activism are associated with the names of Jamal Al-Din Al-Afghani (1838-1897), Mohamed Abduh (1849-1905), and Rashid Reda (1865-1935). Faced with the weakening and subsequent demise of the Ottoman Empire and the preeminence of European powers, all three perceived Islam to have an energizing potential that could restore strength and vitality to the Umma if reason was reappropriated and consecrated to the reinterpretation and revitalization of Islamic heritage. Consequently, a proper understanding of Islam's underlying principles and ethos was necessary in order to discern the path toward progress. This process did not entail wholesale rejection of the West, nor the blind emulation of foreign political, social, or legal

10 Zubaida, 1993: 159. 
systems. Rather it entailed a critical examination of Western sources of strength, namely science and technology. Most importantly, these early Islamists perceived Sharia to be at the core of Islamic civilizational identity. In their quest for progress, they perceived the challenge faced by the Umma as embodied in a renewed interpretation of Islamic law to suit the realities of modernity. It is clear that the turn-of-the-century proponents of an Islamic alternative were intellectuals and reformers who perceived rapid or revolutionary change as unwise and counterproductive. Emphasizing the gradualist yet progressive nature of these earlier Islamists, Halpern points out that the dilemma of Muslims in the Arab world after the deaths of Al-Afghani, Abduh, and Reda, became that of choosing among the conservatism, extremism, or radicalism of their successors. ${ }^{11}$

The Muslim Brothers association, founded by Hassan El-Banna in 1928, took the concept of the Islamic alternative beyond the realm of an intellectual endeavor to that of organized politics and popular agitation. ${ }^{12}$ While Al-Afghani, Abduh, and Reda strove to deal with the intellectual challenges posed by modernism, El-Banna's message was a populist one. He called for a return to Islam as a unifying force that would enable Egyptians, Arabs, and Muslims all over the world to fight colonialism. Consequently, it is reported that by the mid-1940s, El-Banna's followers numbered approximately one million individuals recruited from all over Egypt.

The period following the 1952 revolution was characterized by tension between the regime and the Brothers, who rejected an invitation to participate in the government. Moreover, their discourse became more rigid. Iterating their demands for the imposition of the veil (hijab) and for closure of nightclubs, theaters and cinemas, the Muslim Brothers argued that such measures would prevent the infiltration of Western ideas into Egyptian society. ${ }^{13}$

The Muslim Brother's association was banned in 1954 after a failed attempt on President Gamal Abdel Nasser's life unleashed the wrath of the regime. Many of its leaders and cadres were arrested, some were executed, while others managed to flee the country seeking refuge in a number of Arab and Western countries. Only after President Sadat came to power in 1970 was the association reinstated; its leaders were released and exiled members were encouraged to return to Egypt. The reconciliation included restoring jobs to many of the returnees as well as financial compensation. ${ }^{14}$

Throughout almost three-quarters of a century, the Muslim Brothers stood at different junctures in relation to the government: coalescing with it at times and opposing it at others. While national liberation and political independence were causes that inevitably brought the association and the state together, any attempt by the state at social or legal reform was met with opposition, especially if it fell within the realm of Sharia. The opposition to Decree 44 of 1979 amending the Personal Status Law of 1929 is a case in point. Opposition to what was referred to as "Jihan's law" (named for its sponsor and ardent supporter First Lady Jihan Sadat) was most vehement among the Islamists, both establishment and opposition. They perceived Mrs. Sadat's attempts to reform the Personal Status Law as the ultimate proof of a conspiracy against Sharia. Adding to the intensity of their opposition was the fact that the decree was passed during the summer recess of Parliament, thereby casting doubt on its constitutionality. In fact, the Decree was declared unconstitutional in 1985 by Egypt's Higher Constitutional Court. Law 100 of 1985, which subsequently replaced it, did not add much to the 1929 Personal Status Law. The minor changes that were introduced did not come close to those secured by Decree 44, nor did they reflect the efforts toward greater equity

\footnotetext{
Halpern, 1963: 122.

Zubaida, 1993: 47.

Abdel Nasser, 1994: 52.

Talhami, 1996: 75.
} 
exerted by Egyptian women throughout the century (refer to chapters II and IV, A Century of Struggle and The Public Discourse in Egypt).

The position of the Muslim Brothers has been adopted and continues to be so by representatives of the religious establishment and other conservative elements in society, thereby reflecting the influence they have in shaping the content and structure of the mainstream Islamic discourse. ${ }^{15}$ The length of the movement's duration and its resistance in the face of repression have earned it a measure of respect that its militant offshoots still lack. The Muslim Brothers' violent tendency in the 1940s and 1950s is largely overlooked by most Egyptians; that particular aspect of the movement's history is seen as being part of the resistance against the British and other imperialist forces. The association's initial claim of peaceful advocacy, which it has chosen to reaffirm since the early 1970s, is the aspect most remembered by people. Also, in comparison with other groups, the Muslim Brothers are perceived as rational and moderate. This allows them to provide many of the so-called traditionalists, as well as the general lay public of Muslims, with a frame of reference for the Islamic order.

Following Egypt's defeat in the 1967 Arab-Israeli war, disillusionment with the performance of Nasser's regime set in. A wave of religiosity swept through Egypt, encompassing both Muslims and Christians. Claims that the Virgin Mary had appeared above the Cathedral of Zeitoun came alongside a widespread feeling that the defeat was the result of having abandoned faith in favor of human-made ideas and belief systems. In the same vein, some have noted that the 1973 victory was explained to have resulted from the return to religion. ${ }^{16}$ It was this general mood of religiosity, coupled with state encouragement, that led to the emergence and growing influence of the Islamic groups (Jamaat), and their proliferation first within and then beyond national universities. In his fight against remnants of the Nasserist regime, President Sadat achieved noticeable headway by allowing the Muslim Brothers to reissue their monthly publication El-Da'wa (The Call), and by giving the Islamists a free hand on university campuses. Furthermore, the involvement of Mohamed Osman Ismail, a former governor of Assuit (an Egyptian governorate), has been noted as proof of the state's furtherance of its relationship with the Islamists. Acting as an intermediary between the government and the Islamic groups, Mr. Ismail provided them with directives, as well as financial support. ${ }^{17}$

From the 1970s onward, the relationship between the regime and Islamists began to deteriorate. The first confrontation between them occurred in 1974 when a group of cadets from the Military Academy (MA) attempted a take-over of the academy. The event, which was aborted, was planned as a precursor to a coup d'Ètat, which the cadets perceived as necessary in order to reinstate Islamic rule. The MA incident was followed in 1977 by a confrontation with the group known as Jamaat El-Muslimin, otherwise known as El-Takfir Wal-Hijra (Repentance and Holy Flight). ${ }^{18}$ The deterioration of relations also encompassed the Jamaat. Weary of their influence, the state began to curtail their activities and disallowed the wearing of female niqab, which had begun

\footnotetext{
Gabhat Al-Azhar (The Al-Azhar Front) was established in 1969 as part of Al-Azhar University. Its mission was to protect religious education against attempts at co-optation by the general curriculum. Over the years the Gabha came to represent the Muslim Brothers, albeit informally. While a number of the Gabha members are active in the Muslim Brothers association, the association has enjoyed the sympathy of non-affiliated individuals as well.

Hanafi, 1982: 62-63.

Abdel Atty, 1995: 122-123.

8 For a detailed account of the ideology, organization, and profile of the members of the two groups, refer to Ibrahim, 1982: 117-136.
} 
to appear on university campuses. ${ }^{19}$ The Muslim Brothers fared no better. By 1979, exasperated with the brothers' repeated criticisms of Sadat's domestic and foreign policy, the state retaliated by banning the publication of $E l-D a^{\prime} w a$.

In September 1981, indiscriminate arrests of members of the intelligentsia and opposition preceded President Sadat's assassination in October of the same year by the group known as Jihad. Both the arrests and the assassination exemplified the ambivalence characterizing the interaction between the state and Islamists. ${ }^{20}$ As long as they confined their utterances to issues of morality and social practices, the Islamists were tolerated and even cultivated when necessary. However, criticisms levied at the state's performance were not well-received. On the other hand, the Islamists, especially those associated with the establishment but also the Muslim Brothers, demonstrated over the years that as long as Sharia remained untouched, they were capable and even willing to accommodate and legitimate state policies and directives. Talhami notes that in order to survive and maintain some degree of autonomy, Al-Azhar University developed a dualistic response to the state. While seemingly obedient on the official level, Al-Azhar's contributions to educational thought and practice contradicted and even opposed the modernist premises of the state. ${ }^{21}$

The renewed vitality of Islam as an alternative to secular ideologies has been explained as due to a number of economic, political, and social factors. Economically, the open-door policy (infitah) of the 1970s was perceived as a threat to the middle class, the key strata in Egyptian society. The rank and file of both militant and non-militant Islamic activists come from the middle class. They are the government officials and professionals who lost the edge they had gained during the socialist Nasser era to the new class of businessmen and entrepreneurs that began to emerge in the mid-1970s. Conspicuous lifestyles and excessive consumerism appeared, contrasting with the low key, largely unobtrusive ways of living that had prevailed throughout the 1950s and 1960s. More importantly, the younger elements of the middle class felt they had been short-changed. Young and educated in Egypt's most prestigious universities, they had all the attributes of a professional elite, but none of the opportunities or rewards they had been led to expect. On the political front, the rapprochement with the United States and the subsequent peace treaty with Israel were decried by many in the middle class, who accused Sadat's regime of having sold out to the enemy. The souring of relations with most Arab countries and the loss of its leadership position in the Arab world were perceived as too high a price to pay for the return of the Sinai.

As a result of emigration to the oil-rich Arab countries after the 1967 war, Egyptians were exposed to new values and practices, many of which were absorbed into their lives upon returning to Egypt. Even the practice of Islam was affected by their stay in the more conservative Arab countries.22 Consequently, much of the polemic of the Islamists, including issues related to morality, the family, and gender relations, is derived from or based upon interpretations and practices of Islam that are not the usual moderate ones for which Egyptians are renowned.

Today, Egypt is in the throes of an economic adjustment program. Its costs are high and its benefits have not yet trickled down to the middle and lower classes. Despite the social safety nets that the government has instituted, poverty persists, aggravated by the government's removal of

\footnotetext{
19 The niqab provides full coverage of the head, shoulders, and face except for the eyes. It is considered the ultimate 'Islamic garb.' Two other versions of Islamic attire provide less coverage: the hijab, a scarf covering primarily the hair; and the khimar, which covers both the head and shoulders.

${ }^{20}$ For further information on the Jihad group, refer to Guenena, 1986.

21 Talhami, 1996: 33.

22 Even the tune of the call for prayer (azan) has been affected by migration to the Gulf Arab countries; the tune used is often different from the usual Egyptian version.
} 
subsidies on food and other commodities. Moreover, remittances from migration to oil-rich countries have decreased and, due to the recent attacks on tourists, revenues from tourism have become erratic. These tensions have resulted in an unprecedented rise of violence. Incidents of rape, killing of spouses, and other crimes that were rare until recently, now appear in the press on a daily basis, together with the casualties resulting from confrontations with Islamic militants.

Given that no alternative has emerged to replace it, Islam remains both as an ideal and an idiom. It is a given that is expressed differently by different segments of society. While the majority of Egyptians do not condone violence, they have become more conservative both in outlook and behavior. The upsurge of religiosity is not confined to one social stratum, yet it remains to a large extent a middle class phenomenon.

Resistance to reforming Sharia should be understood in this context. Rigid interpretations of the text and of historical precedents should also be analyzed in relation to a generalized conservative mood that is not propitious to the restructuring of gender relations. Consequently, calls for granting women a more equitable status in society are met with resistance from men, as well as from many women. 


\section{A CENTURY OF STRUGGLE}

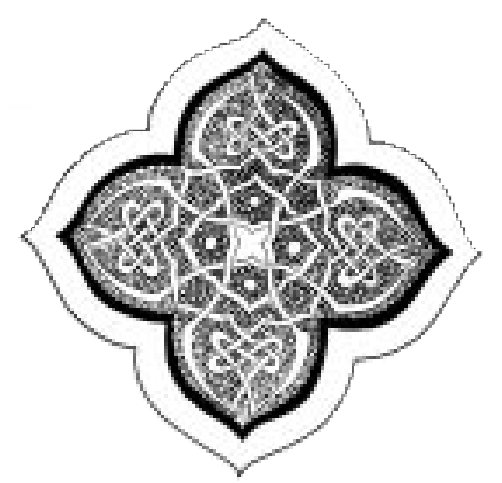

Throughout this century, feminists and women's rights activists have coexisted with different governments and different Islamisms. Their position is difficult due to the fact that "while the boundaries of Islam and the nation are indeterminate and their juxtapositions variable, the centrality of women in guaranteeing the integrity of both is not." ${ }^{23}$ In their attempt to push their cause forward, feminists and women's rights activists adopted different 'umbrellas' under which they placed women's issues. In the early decades of this century, Egyptian feminists affiliated themselves with the nationalist movement and reiterated a discourse of progressive nationalism: the advancement of women would guarantee the nation's advancement. Feminism and women's rights activism have also appeared under other umbrellas, changing over time, liberal, socialist, Islamist, and so on, with the only consistency coming from the fact that women often got shortchanged! As this section illustrates, compromises between governments and other factions are often reached at the expense of women.

The history of the Egyptian women's movement is more than a nostalgic journey into the past; it is the account of a struggle that continues into the present. The patterns of continuity and change in the Egyptian women's movement make it impossible for us to ignore the past, or to discuss the present without a spirit of comparison. The agenda for women's rights today not only includes unmet demands from the 1920s, but has also been enlarged to encompass other issues that were not on that agenda 75 years ago, such as: female genital mutilation, reproductive rights, violence against women, and women-headed households. It is disturbing that some demands from the 1920s that were considered mainstream (such as the abolition of polygamy) are not frequently discussed today, perhaps because they seem to be too ambitious. Even when the Egyptian government signed the Convention on the Elimination of All Forms of Discrimination Against Women (CEDAW), it had reservations on Article 16, among others, which deals with marital relations.

The first part of this section traces the awakening of a feminist consciousness in certain key individuals at the end of the 19th century and the subsequent birth of a movement. The remainder deals with the demands that women have made until the 1970s, both in the laws that govern their lives and in their desire for education, employment, and the right to vote. This section shows how far women have advanced in spite of the obstacles that have faced them, but also how far they

Kandiyoti, 1991: 7. 
need to go to complete the unfinished project of empowerment.

\section{A. FORGING A FEMINIST CONSCIOUSNESS}

\section{"I hated my femininity because it deprived me of the pleasure of learning and leading the active life I used to love." ${ }^{24}$}

The circumstances of women's personal lives in turn-of-the-century Egypt engendered a feminist consciousness, which eventually led to their social, economic, and political participation within society. They contrasted their lives with the freedom and opportunities males enjoyed effortlessly. Aisha Al-Taymouriya, Malak Hifni Nassef, Huda Shaarawi, Nabawiya Musa, Inji Aflatuun, and Doria Shafik, key figures in the women's movement in Egypt, documented these facets of their lives in memoirs and other published and unpublished writings. Towards the end of the 19th century, the 'woman question' (qadiyat al-mar'ah), or women's roles in society, became a much debated issue in the press, in pamphlets, and in books. Following are brief discussions of the contributions of Aisha Al-Taymouriya and Malak Hifni Nassef, who lived and worked prior to the birth of a women's movement, but whose thoughts and works were instrumental in its creation. The contributions of the other women mentioned above are discussed in the context of women's demands throughout this century.

\section{Aisha Al-Taymouriya: A Blocked Writer}

Aisha Al-Taymouriya (1840-1902) $)^{25}$ was one of the first woman writers to express a feminist consciousness in her writings. Due to an enlightened father, she received an early education though it was eventually cut short in deference to family and marital duties. After the death of her husband however, Al-Taymouriya was able to continue her education and her poetry, which spoke to women in the shared language of oppression and pain. ${ }^{26}$ In spite of the advancements that women have made since then, Al-Taymouriya's story is not confined to the previous century: Alifa Rifaat (1930-1996), a gifted short story writer of the 1970s and 1980s, suffered a similar fate. During her married life, in spite of her husband's condemnation of her publishing activities, she continued writing under a pseudonym and without the knowledge of her family. After her husband's death she published her work, and only then under an assumed name. ${ }^{27}$ Different centuries and different

\footnotetext{
Shaarawi, 1981: 43 (author's translation).

For further biographical information on Al-Taymouriya, refer to Fawwaz (n.d.).

Badran and Cooke, 1990: 125.

Fatma Rifaat was her name; her life testimony is translated in Al-Ahram Weekly 28 March-3 April, 1996: 11.
} 
backgrounds separated these women; social restrictions united them.

\section{Malak Hifni Nassef: A Seeker in the Desert}

The generation following Aisha Al-Taymouriya saw the rise of Malak Hifni Nassef (1886-1918), who carried forth the banner of equality (musawah)-with a difference. Malak, a writer and teacher, was one of the first women to write in widely circulated newspapers, but only under the pen name of Bahithat alBadiya (Seeker in the Desert). ${ }^{28}$ After her marriage, she discovered that she was a second-wife and that her husband expected her to tutor his daughter by his first wife. ${ }^{29}$ She was loyal to his wishes during their 11 year marriage, which ended with her premature death. Malak was an advocate of women's rights, yet she believed that things needed to take their natural course and should not be hurried. In response to the writings of Abdelhamid Hamdy

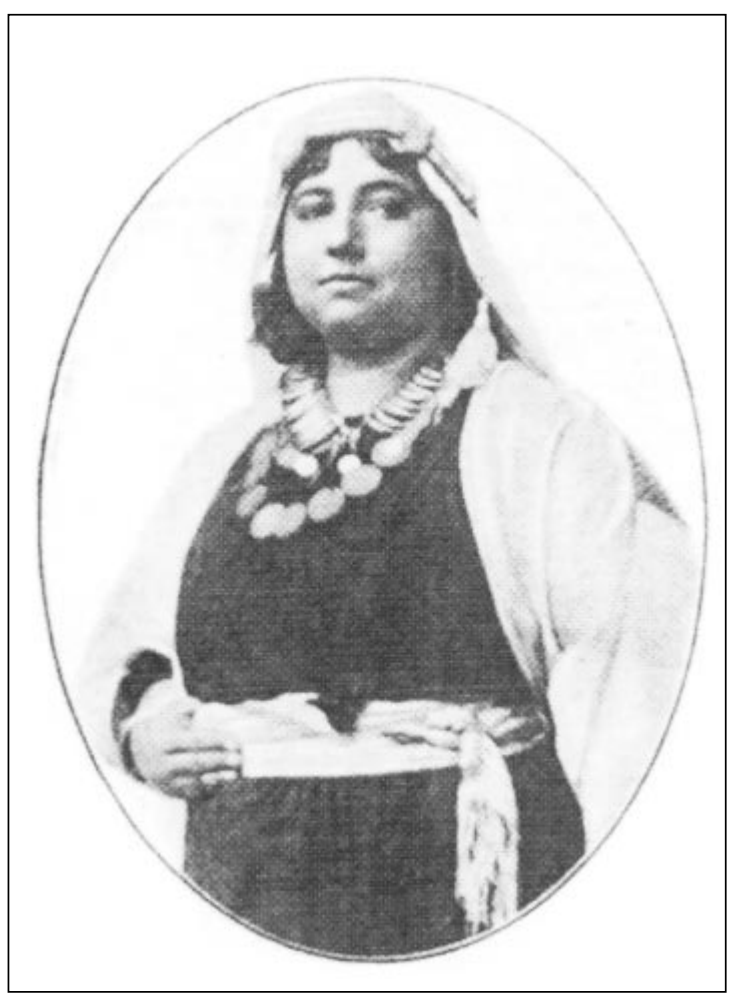

Malak Hifni NasseF (one of the progressive men who championed women's liberation), she wrote an article entitled "Al-Hijab am Al-Sufur" ("Veiling or Unveiling"), in which she argued that society was not ready for unveiled women. She believed that the education of both men and women was a necessary prerequisite to taking the step to unveil..$^{30}$

Malak influenced later feminists who looked to her for inspiration when caught between various currents. Her "writings reveal the tensions inherent in her status as a woman who, although urban-reared, lived a rural existence; and as a nationally prominent author who, while Frencheducated, supported the conservation of religious and national values." ${ }^{131}$ Malak's writings during that period enable us to challenge the commonly held notion that the 'woman question' was a debate authored by 'liberal' males. ${ }^{32}$ As her presence and views attest, women were a strong force within that debate and were capable of articulating themselves. In 1919, the year following Malak's death, Egyptian feminists channeled their consciousness toward creating a more public movement that attempted to improve women's lives.

\section{B. REDEFINITIONS: THE PRIVATE AND PUBLIC SPHERES}

\section{The Seclusion of the Harem: "I have suffered in this cave of isolation."}

The early 1900s were still permeated by the harem system in which urban women from the middle

Musa, 1961: 49-50

Nassef, Majdeddin Hifni, 1924: 50.

Nassef, Malak Hifni, 1910: 24-29.

Early, 1981: 339-341.

For further information refer to Al-Nisa'iyat, which was reissued by the Women and Memory Forum in October 1998.

This is a quote from one of Al-Taymouriya's poetry anthologies entitled Nata'ij al-Ahwal fi al-Aqwal wa-al-Af'al (The Results of Circumstances in Words and Deeds), in which she writes about the harem. 
and upper classes were segregated in their homes, went out infrequently, and only if properly accompanied. ${ }^{34}$ Qasim Amin (1863-1908) ${ }^{35}$ pointed to this seclusion as an injustice in his tracts dealing with the liberation of women. Lower class and rural women had more 'freedom,' since their economic situation obliged them to work.

By 1908 even upper class women had begun to emerge from their seclusion: they came out of their homes to work in charitable institutions, like Mubarrat Mohamed Ali, which furnished people with the services of clinics, hospitals, and dispensaries. ${ }^{36}$ While these institutions provided services to both women and men, men were not involved in the administration. In 1908 a series of lectures at Fouad I University was organized by Huda Shaarawi (1879-1947) and other women from the upper echelons of society. They met on Fridays (a holiday, ensuring that the university would be empty) to hear lectures and to discuss women-related issues. ${ }^{37}$ This was the first recorded effort whereby women carved out a public space for themselves outside the home and within a maledominated institution. Even in a 'segregated setting' male students vehemently opposed the presence of women on the campus. They demonstrated to have the section closed down, prevented women from entering, and made death threats. The women's section was closed in 1912 or 1913. ${ }^{38}$ In both these examples, women emerged from their seclusion but still maintained the segregation of the sexes: their charity work did not involve men directly nor did they frequent the university when men were on the premises.

\section{Segregation and Veiling}

Gender segregation was an integral part of social etiquette and class structure. It could not be transgressed by either sex; the practice of men reading women's words to a male audience testifies to this rigidity. Several incidents are reported in which women sat behind a screen while a male proxy read their speeches. ${ }^{39}$ The religious authorities were a prominent factor in adamantly maintaining segregation; however, it was not always for the purposes of morality-economic motives also came into play. For example, the religious authorities were hesitant to allow women to teach in schools. In theory allowing this would continue segregation since women could teach female students, but it would also have meant that male teachers' jobs would be jeopardized and competition would increase. ${ }^{40}$ This did not mean that religious institutions in Egypt were uniformly against women's demands. They supported them when it suited their purposes: feminists campaigning to end state-licensed prostitution in the 1930s were showered with praise from Al-Azhar University for their social activism, good conscience, and the preservation of society's morals!

The issues of veiling and segregation were inextricably bound. To veil or unveil was widely debated in the Egyptian press in the first two decades of the twentieth century. The veil meant, and still means, different things to people of various classes, ethnic origins, and religions. Earlier this century the veil worn by Christian and Muslim elite was reminiscent of the Turkish culture of

\footnotetext{
For further information on segregation in this era refer to Marsot, 1995; and Tucker, 1985.

An Egyptian lawyer who at the turn of the century published two tracts arguing for the liberation of women. For a good critique of Amin, refer to Ahmed, 1993.

Ahmed asserts that in 21 years of service, the Mubarrat treated 13 million people. In 1964 its hospitals were nationalized.

Ahmed, 1993: 172-173.

Baron, 1994: 184.

Ibid: 184.

Badran, 1996: 58-59.

Baron, 1989: 376.
} 
the Ottoman Empire. Rural women, however, worked unveiled, but with their hair covered for the sake of practicality.1 For many of the progressive men championing female emancipation "the woman's veil was a symbol of her relegation to the private sphere and of the appropriateness of her invisibility and non-participation in public life." ${ }^{42}$

Women metaphorically unveiled in the nineteenth century when they began to found journals and contribute to the press, albeit under pseudonyms. These same journals published pictures of women with accounts of their achievements. In 1923 Huda Shaarawi, one of the best known figures of the women's movement and an ardent nationalist, and Ceza Nabarawi, Shaarawi's protégée, judged that society was ready. Upon their return from a conference in Europe, they unveiled and descended onto the train station platform with their faces showing, but hair covered..$^{43}$ Other women followed their example. By shedding the veil they announced their entry into Egypt's public life and the end of the harem system's cloistering of women. No longer would women remain on the periphery of society, exiled to the home and denied their right to create their future and that of their country.

The practice of veiling decreased dramatically in towns and cities in the middle of this century. Abandoning the veil was associated with becoming educated and participating in building the post-revolutionary society. In recent decades, however, there has been a resurgence. This has been explained by some as a solution to an increasing problem of harassment: "wearing Islamic dress may in fact be a feminist stance in a society that is quick to make life for the unveiled woman insufferable." ${ }^{44}$ This is not the case for all women, but definitely a factor for some. The veil, as it has been adopted more recently, has different associations from the one worn earlier this centuryan issue taken up later in this monograph.

\section{MOVING INTO THE PUBLIC SPHERE AND ITS REPERCUSSIONS}

\section{Woman's Words, Woman's Absence}

In 1910 Malak Hifni Nassef presented her feminist and nationalist demands to the Egyptian Nationalist Congress via a male proxy. Her absence was in accordance with the era's traditional values and "illustrates the reality of segregation." 45 Her demands were aimed at reforming the whole of society. On the feminist front, she demanded access for women to educational and professional opportunities, reforms in the Personal Status Law, and a renewal of the right of women to pray in mosques, a space that had previously been open to them in Islam. ${ }^{46}$

On another front, women's words were being heard in the community through their contributions to the mainstream press and women's journals. These journals started in 1892 with the publication of Hind Nawfal's monthly journal Al-Fatah (The Young Woman). ${ }^{47}$ By the 1920s, it is estimated that there were more than thirty of these journals. The subjects covered varied from household tips to militant articles demanding women's rights and historical vignettes of women's past contributions to Egyptian history. This desire to assert the importance of women both in the

\footnotetext{
Hoffman-Ladd, 1987: 23.

Marsot, 1985: 94 mentions an alternative story where the women had planned to unveil at a function they had organized.

Hoffman-Ladd, 1987: 33.

Baron, 1994: 183.

Nassef, 1910: 123

Baron, 1994: 1.
} 
past and the present added credence to the women's movement. The heavy reliance upon ancient Egyptian history served to authenticate and indigenize women's needs and struggles while proving their contribution to history. Research organizations are again picking up the threads of their ancestors in reassert-

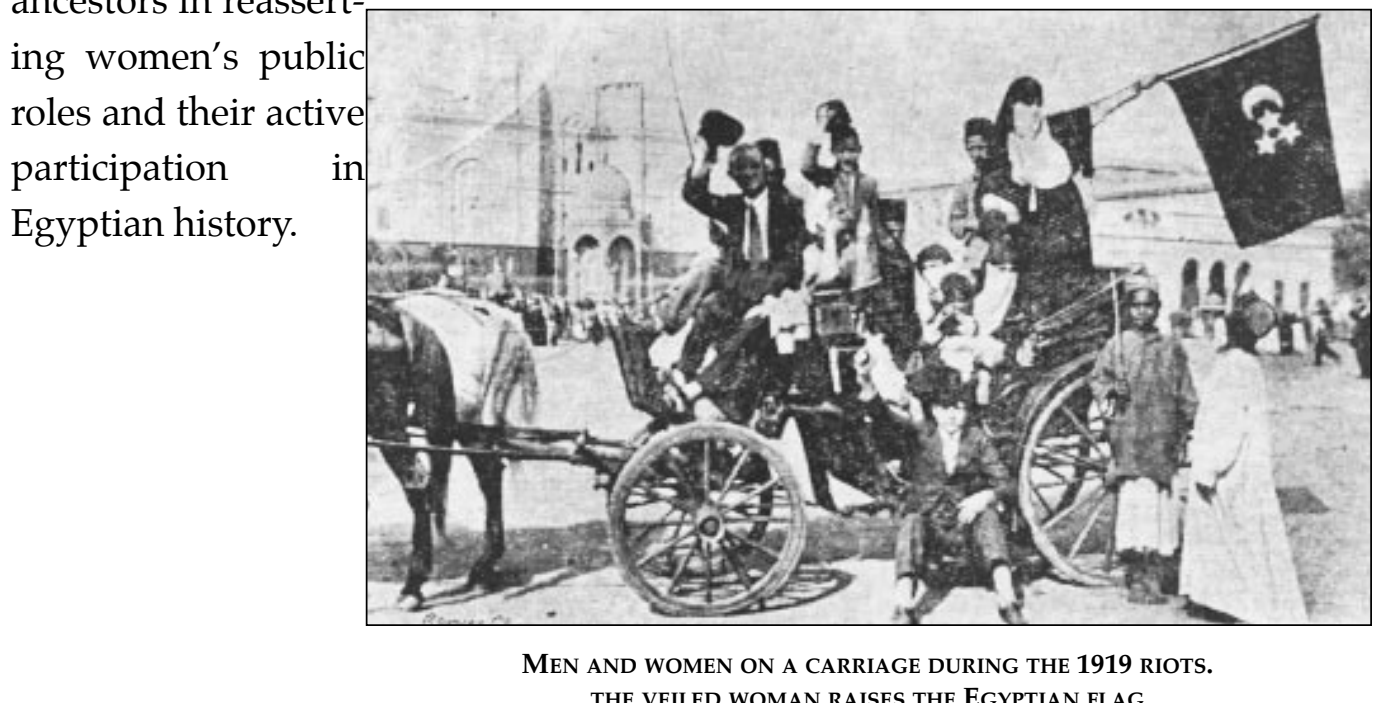

" History matters in the Middle East, and the history of women is being used by scholar/activists to critique narratives favoured by conservative religious and political groups and to challenge constructions of gender based upon those narratives. Research on the history of women and the discourse of gender provides women's advocacy groups with the arguments they need to discredit the myths and misconceptions about Middle Eastern women that prevent them from entering the public space. Because history in the Middle East is so highly politicized, the point still needs to be made that women participated in major historical events and that feminism is not a [W]estern import"..$^{4}$

\section{Feminist Demands, Nationalist Deeds}

In 1919, the year following Malak Hifni Nassef's death, Egypt was in political turmoil and riots broke out. Women of all classes and religions took to the streets: some in cars, others in veils. Huda Shaarawi, described these scenes in her memoirs and highlighted the fact that when the trouble started she was confined to her home, in the spirit of segregation. ${ }^{49}$ The special correspondent of The London Times, Sir Valentine Chirol, described the scene:

In the stormy days of March and April 1919, they [the women] descended in large bodies into the streets, those of the more respectable classes still in veils and shrouded in their loose black

Blanks, 1999: 57.

49 Huda Shaarawi's memoirs (1981) provide a detailed account of the 1919 riots.

50 Philipp, 1978: 288-289. 


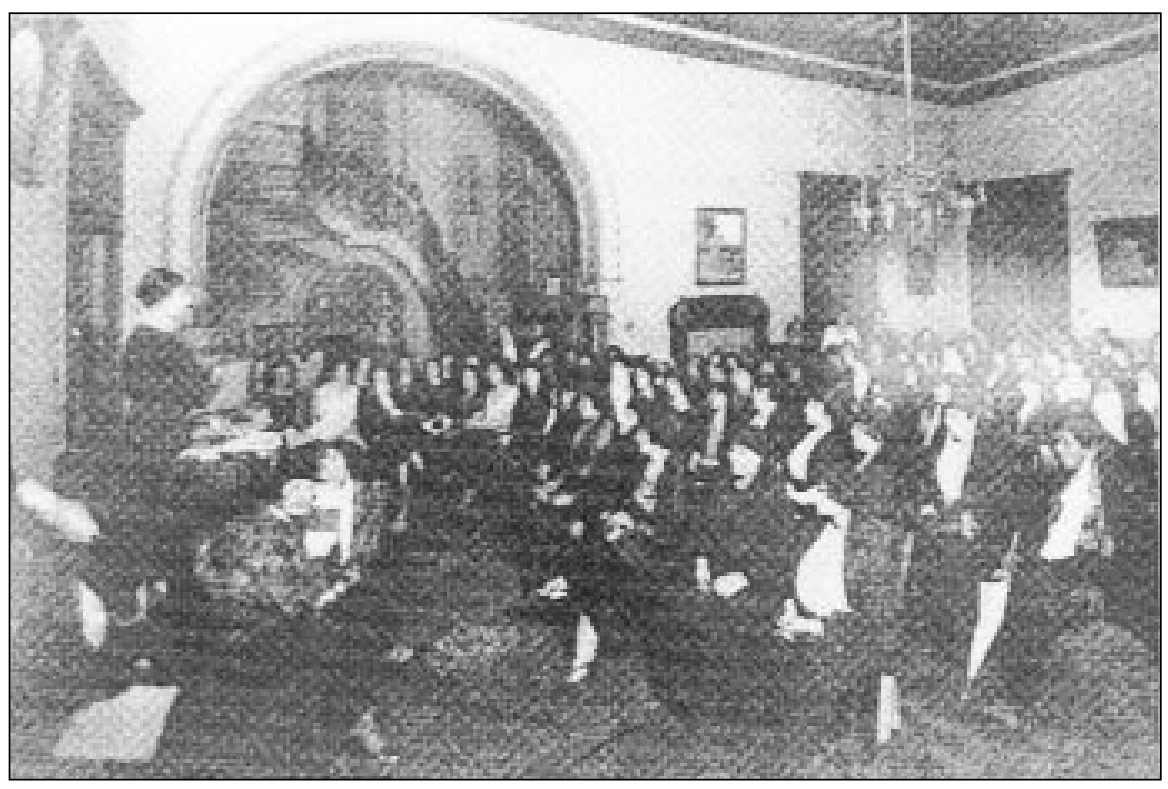

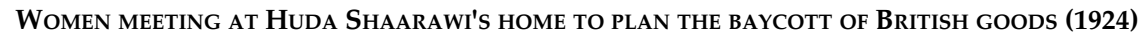

coats,

whilst the courtesans

from the lowest quarters of the city, who had also caught the contagion [of political unrest], disported themselves unveiled

and arrayed in less discreet garments. In every turbulent demonstration, women were well to the front. They marched in procession-some on foot, some in carriages shouting for "Independence" and "Down with the English," and waving national banners. ${ }^{50}$

The first time women ignored the customs of segregation and went out in the streets alongside men was in a moment of extreme violence and social upheaval. Sexual harassment became the most effective weapon against female demonstrators. The British Commandant of police described the scene:

The ladies found their way opposed by a formidable line of Egyptian conscript police, who had been previously warned that they were not to use violence but... considerable license was given them by

\footnotetext{
Russell, 1949: 208 cited in Badran, 1996: 76.

Shaarawi, 1977: 196-7.

Zayat, 1996: 99.
} 
their officers to practice their ready peasant wit on the smart ladies who confronted them. ${ }^{51}$

Sexual harassment was exercised upon veiled, upper class women protesters as a form of control, while physical violence was reserved for lower-class women, several of whom were killed..$^{52}$

This event was a watershed in the history of Egyptian feminism. It marked upper and middle class women's entry into public life and the nationalist struggle. More importantly, women of different classes and religions were united by the same cause. They were in male territory participating in activities commonly dissociated from women's 'nature.' The 1919 revolution also marked the birth and union of the feminist movement with the nationalist one. These feminists and their agenda were subsumed under the larger nationalist umbrella. They had carved a new and legitimate space for themselves. However, with this new space came new threats...

\section{Prison}

...the political activity which had led me to prison was the real and healthy sum of my life in the face of an oppressive, hostile reality, which one must strive to change. ${ }^{3}$

As long as women maintained the socially-constructed boundaries, their protected status was guaranteed. With women's newfound outspoken behaviour, however, came the threat and use of prison as a tool to keep them in check. Alexandra Avierino, who founded the women's magazine Anis al-Jalis (The Intimate Companion) in 1898 in the cosmopolitan city of

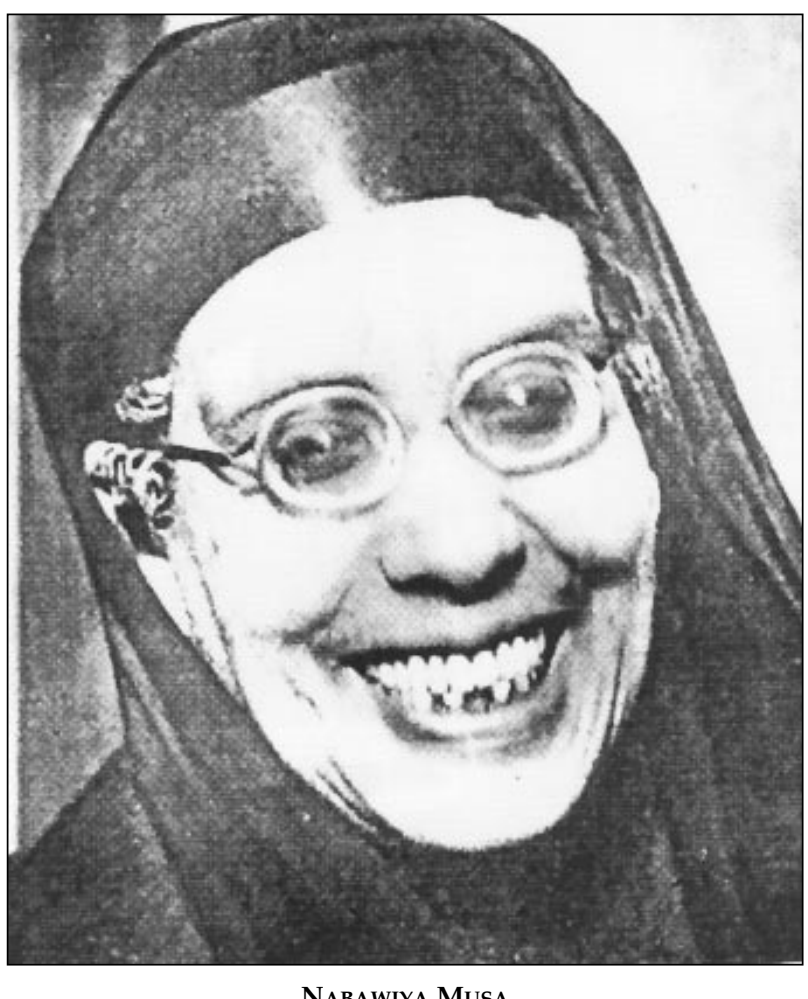

NABAwiYa Musa Alexandria, was one of the first women to go to prison. She is described as having "sought public renown and a role in contemporary events. ${ }^{\prime 54}$ In July 1924 she was arrested on the charge of being involved in an assassination attempt on Prime Minister Saad Zaghloul:

But prosecutors found no incriminating evidence, and after questioning her for several days brought no charges... They considered charging her with using her house for the purposes of prostitution... again, officials found no evidence for their claim. ${ }^{55}$

Trying to discredit women by insinuating their involvement in sexual matters was a tactic later used with other women, but it took different forms. In 1942, Nabawiya Musa (1886-1951) criticized the government, specifically that of Nahhas Pasha, and was imprisoned as a result. ${ }^{56}$ In Musa's life-long

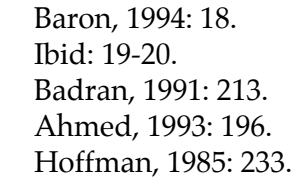


struggle for her rights, she was well-acquainted with institutional harassment tactics. This time, however, her cell mates were prostitutes. Linking the pioneer of women's education, the respected school teacher, the admired headmistress, and the first woman to get equal pay in a government job, with 'women of ill repute' was an obvious strike at her morality. Musa's imprisonment was rare for a woman of her status; however, by the middle of the century that had changed.

During the 1960s, women from the entire political spectrum were subject to imprisonment. Inji Aflatuun (1924-87), an artist, political activist, and feminist, was imprisoned for her views. Latifa Al-Zayat (1926-1996), a novelist, activist, and member of the communist student organization at Cairo University, described her own experiences. She remembers being harassed by Muslim fundamentalist students who "tried to defame my reputation-they called me a prostitute..." ${ }^{57}$ During the 1960's and 1970s she was imprisoned by the government for her political views. The 1970s saw even more women imprisoned for their political views. Islamist women were at the other end of the political spectrum. In the 1960s mounting concern over the influence of the Muslim Brotherhood reached a crescendo, especially after the assassination attempt on President Nasser in 1954. Zeinab Al-Ghazali (1917- ), the founder of the Muslim Women's Association and a previous renegade member of the Egyptian Feminist Union, was imprisoned in 1965 amidst "a new round of arrests of Brotherhood members." ${ }^{158}$ She had survived the first round of arrests earlier in the decade. Al-Ghazali was released six years later after having withstood torture, which she documented in her memoirs. ${ }^{59}$

According to these women's accounts, their sexuality was used against them. This is a common thread that transgresses the boundaries of time and political affiliation. Accusing Avierino of using her home for prostitution; Musa's sojourn with prostitutes in jail; Al-Zayat's labeling as a prostitute; and the physical violence Al-Ghazali experienced illustrate attempts to suppress women by tarnishing or violating their sexuality through speech or action.

\section{ARTICULATING FEMINIST DEMANDS}

\section{Public Voice, Public Persona}

In the 1920s a group of women became a political force within the Egyptian nationalist struggle. Huda Shaarawi was president of the Wafdist Women's Central Committee, which operated closely with the Wafd party. Once the Wafd gained power and a constitution was drafted, the women discovered that they had been left out and were not granted the rights they had been promised. Women's needs were subsumed by the larger nationalist cause and relegated to the bottom of the group's priorities. This short-lived alliance was based on a symbiotic relationship: women had gained legitimacy through their alliance with the nationalist Wafd party, and the Wafd had used the women to rally the people when the British imprisoned or exiled party leaders. However, after

\footnotetext{
Al-Ghazali, n.d.

${ }_{60}$ The founding members, according to EFU by-laws, were Huda Shaarawi, Ihsan al-Qusi, Gamila Abou Shanab, Ceza Nabarawi, Aziza Fawzi, and Mary Kahil. Some of the women mentioned in this section joined later and membership of the EFU increased over time.

61 Further information and theory on this issue, refer to Hatem, 1993: 29-48.

62 Kandiyoti, 1996: 9.
} 
the Wafd party reneged on its promises, women needed a new forum: in 1923 the Egyptian Feminist Union (EFU) was created.

The EFU was made up of Coptic and Muslim women from the upper and upper middle classes.$^{60}$ The EFU's demands were split into three sections: political (mainly nationalist), social, and feminist. By placing feminist demands last, they decentered women's rights and placed them within a nationalist framework-the advancement of women guarantees a nation's improvement. ${ }^{61}$ In light of the alliance that existed between these women and the nationalist cause, they continued to utilize the nationalist discourse to strengthen their position. Malak Hifni Nassef used this argument to advocate women's education, as did Nabawiya Musa in defending women's right to work.

Throughout the EFU's most active years (1923-1947), its members were treading a fine line between government and religious forces-not wishing to antagonize either, and in the process, negotiating their at first peripheral existence. Therefore while the feminists did want change and reform, they did not want to be too critical in matters touched by religion. This was problematic because:

the strong identification of cultural authenticity with Islam has meant that feminist discourse could only legitimately proceed in two directions: either denying that Islamic practices are necessarily oppressive or asserting that oppressive practices are not necessarily Islamic. ${ }^{62}$

The feminist demands that the EFU made 75 years ago are still pertinent to the lives of women today. Some progress has been made, but the various governments' lack of commitment to women's issues and their tendency to compromise on women's issues, has threatened to undo what women had previously achieved. The following is a discussion of the EFU's demands. Except for a few concessions, the feminist agenda has not radically changed, but has expanded to cover more ground.

\section{E. REDEFINITIONS OF WOMEN AND THE FAMILY: PERSONAL STATUS LAW}

When drafting laws earlier this century, a compromise was reached: secular law was used in civil, commercial and penal codes, while the family and the governance of the personal lives of men and women remained under Islamic law. ${ }^{63}$

As a result articles of personal status codes often conflict with the constitutions of Arab countries. While the latter guarantee equal rights for all their citizens, the former extend privileges to men in the family (in the areas of marriage, divorce, and child custody) which are denied to women. ${ }^{64}$

The family is often identified as a primary location of women's oppression. ${ }^{65}$ Given that the Personal Status Law "organizes the relationship of marriage through all its stages," ${ }^{\prime 66}$ it has a tremendous impact on gender and power hierarchies within the family. It was issued in 1925 as Law 25, then amended in 1929. More recently changes have taken place in 1979 and in 1985. In general, "the [P]ersonal [S]tatus [L]aws dealt with women as part of the regulation of the organi-

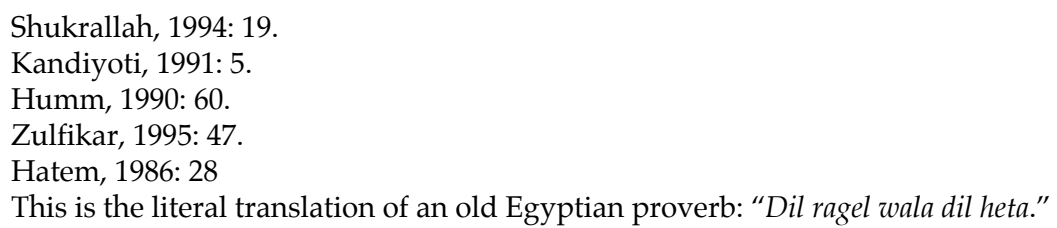


zation of the family, not as individuals with their own separate or equal rights." ${ }^{67}$ The following section of the monograph traces the demands of the EFU regarding the Personal Status Law and further attempts to modify it through to the 1970s. Throughout the 1920s, the governments in power avoided eliciting any change in the laws so as not to upset the imbalance between the genders. This was in direct contrast to the changes taking place for women in the realms of education and work. The entire mechanisms of society could alter but the patriarchal family unit was guarded from any such change.

\section{Polygamy: "The shade of a man is better than that of a wall." ${ }^{68}$}

When the EFU set forth an agenda in 1923, one of the most pressing issues necessitating reform was the Personal Status Law, a form of discrimination that feminists experienced first-hand. Huda Shaarawi and Malak Hifni Nassef both discovered their co-wife status after their marriages. EFU women wanted to curtail the practice of polygamy because it threatened women and children in its destruction of families. A man's right to marry up to four wives was used as an intimidation tactic to keep a wife in check. "Women feel constrained to be exemplary wives in every respect...the introduction of a new wife into the household means a division of material resources as well as of affection." ${ }^{\prime \prime 9}$ Earlier this century it was an extremely common practice: Umm Kulthum, the legendary singer, remembers that: "my father never took another wife. This was not common then in the rif (countryside); not even in our family itself, for I had three uncles and each of them had married two or three times." ${ }^{\prime 70}$

Earlier Imam Mohamed Abdu (1849-1905) had described in his memoirs the problems faced by women and denounced polygamy altogether. ${ }^{71}$ In 1927 the EFU's amendments restricting polygamy and the male right to divorce, based on the views of Mohamed Abdu, were presented in draft form to the Cabinet and were approved. The amendments sought were not in contradiction to the spirit of Islamic teachings, yet King Fouad denied them his support. ${ }^{72}$ This situation expresses the divisions within government and dismantles the idea that governments are monolithic entities. It also foreshadows subsequent incidents in which attempts at reform were aborted at various levels of the decisionmaking process.

Even though the EFU met with no success in implementing reforms, attempts to elicit change in the Personal Status Law continued. In 1972 and 1974, Aisha Rateb (the Minister of Social Affairs at the time) attempted to elicit reforms dealing with divorce and polygamy. Her suggestions, which were also grounded in Islam and its teachings, were again refused. The reaction to them was more telling of the social atmosphere.

The 1974 proposal even elicited a protest march from the Al-Azhar community of 'ulama [scholars] and students upon the People's Assembly and President Sadat promised in a public speech that no action on the proposal was presently contemplated by the Assembly. ${ }^{73}$

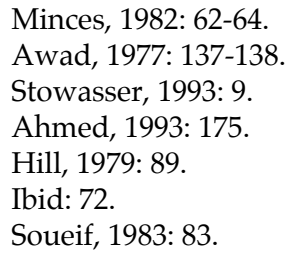


Yet another proposal was put forward in May 1977 with no success. In Egypt polygamy is still the legally and religiously sanctioned right of Muslim men. This is in direct conflict with the Egyptian National Charter (1962), which claims that "the family is the first cell of society and therefore, in the national interest, it must be afforded all means of protection." ${ }^{\prime 74}$ Women's needs and demands were short-changed yet again. Even when a faction within the government attempts to institute some reform, the remainder of the government will often give in to the more conservative strands of public opinion. This normally happens regarding women's issues, but with other policies the government often enforces them regardless of public protest. Unfortunately, most of the compromises and concessions seem to take place in the domain of and at the expense of women's rights.

\section{Divorce and Custody: "...he was my husband and any time he wanted to do anything to me I must let him and not fight him. ${ }^{\prime \prime 6}$}

Divorce is the dissolution of the marriage contract. A man's right to divorce his wife without witnesses or recourse to a court, sanctioned in Sharia, was a source of concern to EFU women and victims of this law alike. Law 24 of 1920 claimed that if a husband was unable to support the wife or if he suffered from an irreversible illness, a woman had grounds for divorce. However, divorce still remained a male utterance in private and not a reality debated in a court of law. ${ }^{76}$

When these laws were being revised in 1929, the only advance EFU members succeeded in making was to insert the amendment that a man could not pronounce himself divorced from his wife if it was in a moment of duress, and that a wife could ask for a divorce. These guaranteed nothing. Women could be granted a divorce if they could prove that their current marital situation was in some way harming (darar) them. Unfortunately the final judgement was left to male judges who might or might not be sympathetic. Of course, the repercussions of divorce affect women from various classes in radically different ways. From the early decades of the century until today, the reality is that alimony or compensation are rarely paid to the wife, who is left to fend for herself.

Custody, a mother's right to keep her children until they are of a certain age, was extended from ages seven for boys and nine for girls in 1929 to ages ten and twelve respectively in 1979. ${ }^{77}$ However, in both cases the judge is allowed to exercise his discretion in extending the duration of custody. Should the mother remarry, she loses custody of her children, while the father never loses that right. Again the realities of this law affect women differently depending on socio-economic factors: a wife's recourse to the legal system is an expensive and time-consuming option, making it virtually inaccessible to poor women. Moreover, even if there were gender-sensitive laws, the general lack of legal literacy among women is an impediment to the attainment of their rights, as are the biased attitudes of male judges.

\section{Bayt al ta'ah: "I had married, and so found myself living behind bars."}

Bayt al-ta'ah (house of obedience) is not derived from or related to the Quran [Islamic Holy Book] or Sunna [the practice of the Prophet], yet it is law. The idea of bayt al-ta'ah is inextricably linked to

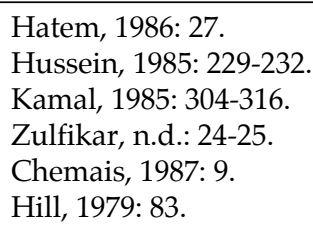


a man's right to demand obedience of his wife. The origin of bayt al-ta'ah is the belief that a wife must remain in the conjugal home and obey her husband in exchange for his financial support. Should she leave the conjugal home (hence disobeying her husband) then he has the right to order her back, either to their home or to another that fulfils certain criteria. The criteria for this abode are that it "should normally be a suitable healthy place for the family, duly equipped and furnished and not shared with other families." ${ }^{\prime 79}$ It is advised by the law that neighbours should be near enough "to be able to hear the scream of the wife and therefore be witnesses on what takes place between the married couple." ${ }^{\prime 0}$ This stipulation offers a hint about the nature of the relationship between the spouses, especially when the husband forces his wife to return to him and obey his commands against her will. Bayt al-ta'ah has been used by men as a loophole to avoid alimony payments to the wife: if the wife refuses to go to bayt al-ta'ah then she becomes deviant (nashez) and forfeits her right to alimony upon divorce.

The EFU campaigned for its abolition in the 1920s but was unsuccessful. There was an amendment to the bayt al-ta'ah law on 13 February 1967: a Ministerial order was issued that prohibited the use of the police to bring a woman back to the house. ${ }^{81}$ Attempts to abolish it have continued through the decades to no avail. This situation is sanctioned by society, protected by legislation, and apparently exempt from change because it is falsely ascribed to religion.

4. Minimum Marriage Age: "My father was not punished for having married me off when I was a legal minor." ${ }^{\prime 2}$

Again, feminists' perceptions of women's problems came from their own experiences. Huda Shaarawi's marriage in her early teens to her cousin, a man much older than she, served as a reminder of the negative implications of marriage at a young age. In the 1920's, the EFU petitioned the government to set a minimum marriage age. Parliament acquiesced and set the minimum marriage age for girls and boys at 16 and 18 respectively. ${ }^{83}$ Unfortunately, at least for girls, this law is rarely enforced and falsification of the necessary documents is easily achieved. Moreover, as usual, a law governing minimum marriage age affects segments of society differently. It is supportive for middle and upper class families who want to continue the education of their daughters. The law also encourages the completion and attainment of school degrees for boys (at age 18), whereas girls' education can be curtailed earlier (at age 16), implying that it is of secondary importance. The dangers of early childbearing and the problems of access to health care are exacerbated by this law.

\section{F. FORGING A PUBLIC EXISTENCE}

Reform within the family was not sufficient; women wanted access to a public life within society. To realize equal rights and equal citizenship, women needed: an education, the right to work in the profession of their choice, and the right to vote. Denied these rights and life options, they were homebound within a domestic power hierarchy. This hierarchy was rarely favourable to them as

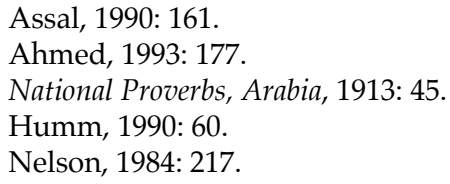


they were always social dependents.

\section{Education: "The eyes are of little use if the mind be blind." ${ }^{84}$}

Education has been an area in which women have met with triumph. Precisely because education is a powerful tool through which "the state reproduces the gender and social relations of production," ${ }^{85}$ the EFU prioritized it on their agenda. This emphasis on education began within urban areas and gradually spread to the rural areas. The history of education in Egypt displays an interweaving of religion, colonialism, modernity, and the government:

The legacy of the nineteenth century was to create a dichotomy of cultural outlook produced by the introduction of a State school system modeled on European lines and the expansion of the missionary and foreign community schools, superimposed on the religious Kuttab system... the religious schools continued to provide a rudimentary education for the masses in the form of the three Rs (reading, writing, and arithmetic), while the modern government schools provided a secular European style education for the existing and aspiring elite. ${ }^{86}$

In 1873 the first state girls' primary school was created, teaching its pupils religion, mathematics, history, geography, and home economics. However, girls were not entitled to sit for a final examination until 17 years later. ${ }^{87}$ Qasim Amin's nationalist and 'emancipatory' discourse propagated education because it enhanced women, but only in service to the nation to produce better children, not to grant women greater life opportunities. Women themselves espoused this discourse; some believed in it genuinely while others used it as a loophole to get what they wanted:-an education. Enter Nabawiya Musa.

Nabawiya Musa was a pioneer of women's education and many of the rights that Egyptian women hold today in this field are largely due to her struggle..$^{88}$ In 1906 Musa was the first woman to receive a degree from the Sanniya School for Girls. ${ }^{89}$ Salama Musa, a famous writer and journalist, wrote in his autobiography:

...we witnessed Miss Nabawiya Musa's success as the first young woman who obtained her secondary school certificate, though Dunlop [the British education adviser] had placed many obstacles in her way. ${ }^{90}$

She later worked as a teacher, headmistress, and administrator, and was appointed inspector of female education in 1924. In narrating her life, Musa makes links between women's status, discrimination, education, and work:

I filled out the application to sit for the baccalaureate examination and sent it in on time to the

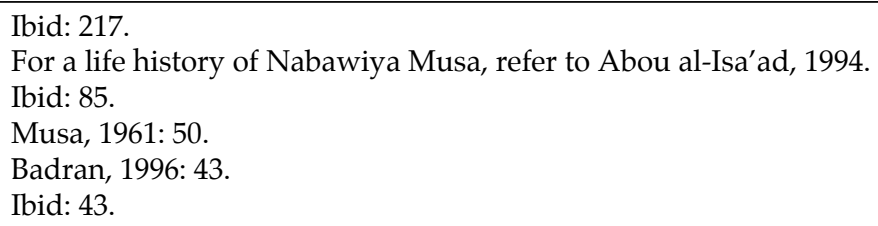


Ministry of Education. The men of the ministry went into an uproar over it...they thought it preposterous...Mr. Dunlop came to me at the 'Abbas School with my application in hand. He gave it to me laughing...91

The day she went to sit for the examination, Musa remembers:

...My brother accompanied me...we would sit at the back of the tram not to attract the attention of the male students but their talk poured over my head. Some of them vowed to beat the girl student should she fail in the examination. And of course she would fail. She applied to sit for the examination only to show her beauty and charms. They paid no attention to me because I was not the person of their imagination...The girl sitting at the back of the tram was modest, and no one would think for a moment that she could read..$^{92}$

Musa entered and left the building from the back door to avoid the threat of violence that awaited her. After passing the examination, she fought for a teaching post and received equal pay. This was an exception in the field of education for a long time to come. In this defiant act she asserted women's right to education, work, and equal pay-as well as dealing a blow to the British colonialist ethos.

Based on the 1924 Constitution, which stated "that obligatory free elementary education extended also to girls, ${ }^{\prime 93}$ the EFU demanded that the state create secondary schools for girls, teaching them the same curriculum that boys received. The Minister of Education, Ali Maher, consented to the EFU's request, and the Shubra Secondary School was opened in 1925, almost four decades after the first boys' secondary school. In spite of this, in 1927, slightly more than 2 percent of women were literate compared to just over 11 percent of men. ${ }^{94}$ It was only after independence in 1929 that women obtained Secondary School certificates, 22 years after Musa's triumph..$^{95}$ The complex relationship between colonialism, the state, and chauvinism was one of the main factors that held women's schooling back. The colonial powers did not want women to excel in the teaching profession because that jeopardized British men and women's consolidation of these jobs. Nor did they want Egyptian women (seen as a weaker faction in society) asserting their autonomy to a colonized people-not to mention the prejudices of both patriarchal societies. Gender-based discrimination was reinforced by the colonial presence.

Musa's career as an inspector in the Ministry of Education ended in 1926. "It appears that her criticism of certain high officials in the Ministry of Education for conduct that today would be called sexual harassment finally led to her expulsion." ${ }^{\prime 96}$ Although a modest and religious woman, Musa faced constant harassment because she was a woman, and her presence reminded male teachers that their jobs were in jeopardy. Sheikhs who taught Arabic did not want women taking

\footnotetext{
Philipp, 1978: 285

Nelson, 1984: 219.

Badran, 1992: 272.

Badran, 1996: 177.

Baron, 1994: 185.

Badran, 1996: 148-9.

Yadlin, 1995: 161.

Nelson, 1984: 220.

Minces, 1984: 96.
} 
their jobs, yet they also advocated segregation of the sexes in education. It was precisely this contradiction that opened the door to Musa.

Once the hurdle of secondary schools had been crossed, the next battle was on the university campus. Fouad I University (now Cairo University) was supposedly open to all Egyptians, yet women were not permitted to study there. Ironically, it was Princess Fatma Ismail who had donated the money for the construction and maintenance of the University. ${ }^{97}$ In 1929, a progressive rector of the university, Ahmed Lutfi al-Sayyid, allowed a group of women to enter. Women and men sat far apart from one another. Women feared that their reputations would be tarnished if they were seen to mix with the other sex. ${ }^{98}$ Eventually, over the years, women entered the university in greater numbers. However, the real watershed that mainstreamed the idea of women's education came with the 1952 revolution.

Education became one of the tools employed by President Nasser to achieve progress and national and cultural unity. Through politics and education, the Nasser regime preached to all, "not only purely political values such as democracy, socialism, and cooperation, but also civil values such as equality, awareness, and responsibility, the value of productive work, the potential of free will, and rationalism." 19961 saw women's unprecedented entrance into Al-Azhar University, which had just undergone a modernization scheme. ${ }^{100}$ In the 1960 s coeducation became prevalent in state schools out of necessity: there was both a lack of teachers and of buildings. ${ }^{101}$ This this was not intended for women's benefit; rather, it came about coincidentally because of the scarcity of resources. Even with government support, the education system could not adequately address the needs of the people.

\section{Work: "The best way to serve this country we are ready to die for is to direct women's atten- tion to education and work." ${ }^{102}$}

As Musa's story illustrates, government jobs were not easily accessible to women and if they were able to secure them, they were usually discriminated against in their wages. Also, once married, a woman could no longer retain her teaching post or any other government job. Obtaining an education proved to be much easier than finding a job. The very notion of work for women outside the home was threatening on three levels: earning an income liberated women from dependency on men; work outside the home meant women's protrusion into a public and previously male domain; and as Musa's life displayed, men did not want women to rival them in the job market. ${ }^{103}$

The employment issue had different implications for different classes. A myth surrounded upper and lower class women, that they did not really work. In actuality their "managerial effort and expertise... contributed to the financial resources of the family." ${ }^{104}$ Women of the lower classes already worked within their homes and in rural areas laboured in the fields with their families. This was not acknowledged as work, and naturally they were not paid. As a result this last group was not included in the debate about women's work. When Nabawiya Musa, Huda Shaarawi, and other feminists campaigned for women's right to work, they were probably targeting women from the middle and upper classes who were by then getting an education and wanted employment

\footnotetext{
Musa, 1920.

Badran, 1996: 165.

Macleod, 1991: 49.

Ahmed, 1993: 190-191.

6 Hatem, 1986: 30.
} 
after graduating.

In advancing their agenda, the EFU addressed the employment issue as a nationalist one whereby women could liberate themselves and in doing so would contribute to the liberation of their country. The argument men used against women's presence in the workplace was that they would subject themselves to sexual exploitation, leading to a loosening of the country's morals. The latent content of this debate was that women's work opportunities detracted from men's.

In the 1920s Egyptian women began to work in factories producing cigarettes, textiles, and pharmaceuticals because they were a cheaper source of labor than men. Eventually however, they were replaced by machines. By 1937, 11,000 secondary school and university graduates of both genders were unemployed, making the situation graver for women, who had the added burden of sexual discrimination when seeking employment. ${ }^{105}$ For those who had jobs, the situation was difficult. To ensure women's security and limit sexual discrimination, the EFU campaigned for improved working conditions. In 1933 a labor law was passed regarding women's employment. It delineated the kinds of jobs women could have, the number of hours per day they could work, allowed them maternity leave, access to day care centers, and flexible working hours during the lactation period. The consequence of this law was that employers became hesitant to hire women because of the added expense of these benefits. ${ }^{106}$ These laws were on the whole not enforced and women complained of the work hours they kept and the conditions in which they worked. The EFU demanded that the government take action. They responded by hiring Na'imah Al-Ayyubi as the first inspector of women's work in 1935. ${ }^{107}$

While the post-revolutionary government (1952) was seen to encourage women to obtain an education and seek employment, the Egyptian National Charter (1962) sent contradictory messages. It told women that the family was their primary concern, and that they alone were "to preserve the national tradition" within society. ${ }^{108}$ In 1963 laws were passed promoting the idea of equal pay for equal work and equal right to promotion between men and women. ${ }^{109}$

In 1962 a woman named Hekmat Abou Zeid was appointed Minister of Social Affairs. ${ }^{110}$ During this time, the socialist government was still sending mixed messages to Egyptian women. During Sadat's rule (1970-1981), a new constitution was passed. According to Article 11 of that Constitution:

...the State guarantees the reconciliation of woman's duties toward her family with her work in society, and her equality with man in the political, social, cultural, and economic fields of life without prejudice to the principles of Islamic Sharia. ${ }^{111}$

Men's duties to that family are not mentioned and women are painted as torn between their primary concern (the home) and their adopted environment (work outside the home). Furthermore article 9 states that:

\footnotetext{
107 Badran, 1996: 175.

108 Nelson, 1984: 221.

Hatem, 1986: 29

110 Ahmed, 1993: 210

Zulfikar, 1995: 135.

112 Hatem, 1986: 31.

113 This is a line from a song by Sayed Darwish entitled Banat al Yom (Today's Girls) from the early decades of this century. His music was exceedingly popular for its passionate nationalism. The lyric in Arabic actually says, "Ishm'ina il sitat fi oroba b'yudu sot'hom fi il intikhabat?"

114 Badran, 1996: 207.
} 
"the family is at the base of the society and is shaped by religion, ethics, and nationalism. The state pledges to preserve this genuine character of the Egyptian family, the customs and values it represents, and to generalize them to the rest of the society."

Given the emphasis of Islam on women's roles as wives and mothers,

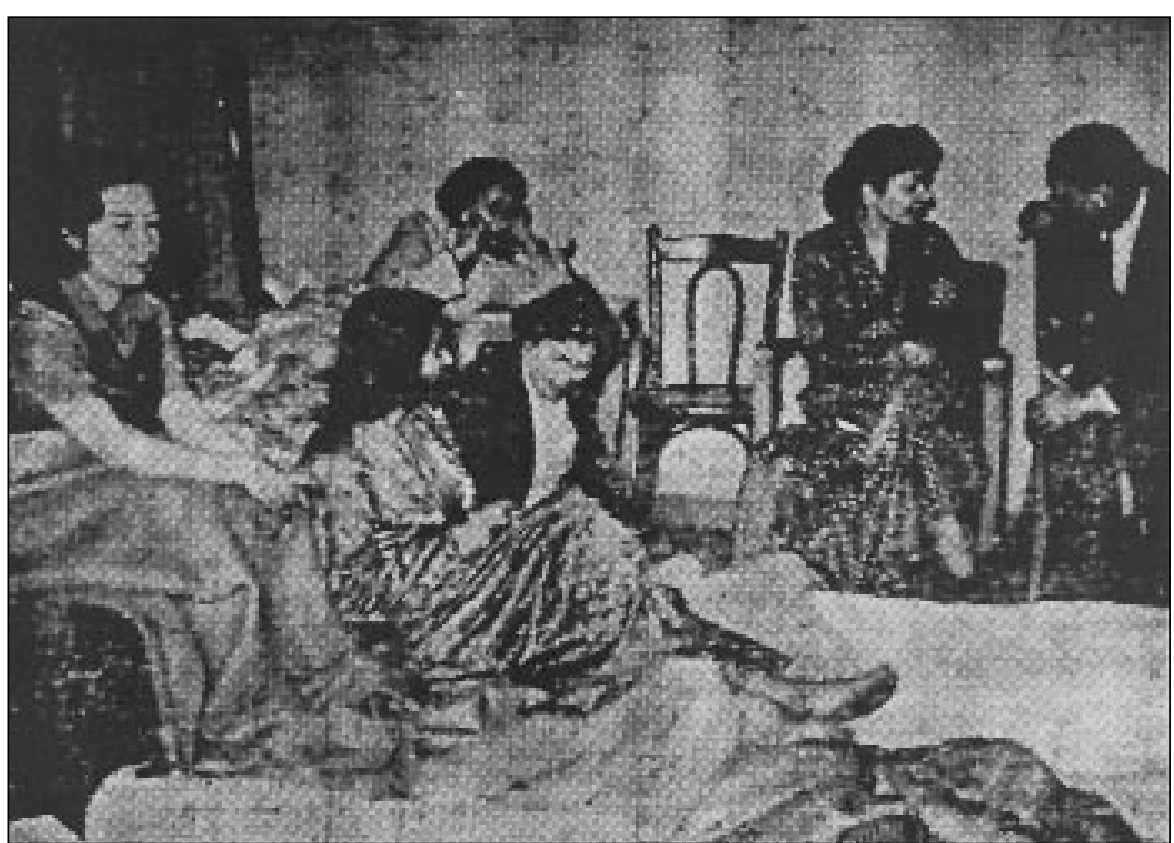

DORIA SHAFIK WITHOTHER WOMEN ON THE HUNGER STRIKE IN THE JOURNALISTS' SYNDICATE grounding women within the religious and nationalist framework was highly constricting. ${ }^{112}$ Interestingly enough, a strand of nationalist thinking looks upon women as the producers of good sons that will add to the nation's glory, not unlike the previous stance.

\section{The Vote: "Why Can Women Vote in Europe?"113}

In the EFU's demands, a section entitled "Amendments to the Constitution," stated that all citizens should be allowed to vote. The EFU women were not disappointed when in 1923, the new Constitution propagated the vote for all. The surprise came three weeks later when an electoral law was passed giving only men the vote. ${ }^{114}$ To add insult to injury, the newly elected government opened the first session of Parliament without inviting the women who had helped them come into power (that is, the EFU members who had earlier formed the Wafdist Women's Central Committee and dissolved it to form the EFU). Only the wives of officials and foreign women were allowed in. ${ }^{115}$

Women's attempts to participate in political life were further thwarted by the government and the British, culminating in violent demonstrations and arrests. ${ }^{116}$ The struggle for the vote continued through the 1930s with the EFU's Committee to Demand Women's Social and Political Rights, making little progress. ${ }^{117}$ The Second World War stifled the debate and the death of Huda Shaarawi in 1947 left the EFU without leadership. A new force emerged on the scene carrying on the fight for suffrage: Doria Shafik (1908-1975) and her organization Ittihad Bint al-Nil (Daughter of the Nile Union).

\footnotetext{
115 Shaarawi, 1981: 296.

116 For further information refer to Badran, 1996: 210-212.

117 Arafa, 1954: 27.

118 Khater and Nelson, 1988: 468.

119 Ibid: 469.

${ }^{120}$ For a more detailed account refer to the chapter entitled "Storming the Parliament" in Nelson, 1996.

121 Hosni, n.d.

122 Khater and Nelson, 1988: 472.

123 Ahmed, 1993: 210.
} 
Doria Shafik was from the generation following Huda Shaarawi and of middle class origin. There were other feminist and political organizations during the 1950s, but for Shafik "the right to vote as well as changing the socioeconomic system which underlaid the oppression of women had to be the goals of the feminist movement."118 Shafik founded two magazines, to which people wrote seeking advice. Shafik responded by trying to mobilize men within the legislative bodies to address women's needs. She was unsuccessful. "It was obvious to me," she wrote in her memoirs, "that women representatives were essential in Parliament." 119 The rebirth of a political movement followed, aiming to secure women the right to vote and adequate political representation. The culmination of their efforts came on 19 February, 1951 when almost 1,500 women from different political groups and with opposing beliefs, headed by Shafik, organized a march on Parliament demanding their rights. ${ }^{120}$ The women were told that their requests would be given serious thought, but the government remained silent. On 12 March 1954 Shafik and eighteen other women went on a hunger strike in protest. ${ }^{121}$ They were promised that the matter would be consideredthis time by the new, socialist, revolutionary government. Two years later, in 1956, women won the right to vote. ${ }^{122}$

The march on Parliament and the hunger strike were perceived as radical acts; however, women had tried to negotiate with the government both times and had been completely disregarded. By 1957 modest changes occurred, with two women elected to the National Assembly. ${ }^{123}$ Finally, women's voices would be heard and they would have some of their civil rights. Armed with the right to vote, women felt that the door was open. Or was it?

The 1960s and 1970s were ambiguous decades for women's rights. There was a general silencing of all groups, including women's organizations, perceived to be too 'political.' During the 1970s, First Lady Jihan Al-Sadat's voice dominated, but her position as the President's wife often worked against what she tried to achieve. Women who were not part of the 'official' regime, like Nawal El-Saadawi (whose feminist organization was eventually closed down), were silenced. However, the United Nations Decade for Women (1975-1985) began to revitalize the issue in Egypt. This coincided with increased disillusionment from unfulfilled promises over women's rights, whether from the government or other movements that proposed alternative systems. The rise of Islamism also forced "middle class women to organize themselves in opposition to its socially restrictive goals." ${ }^{124}$ But the question still remains: how are Egyptian women faring today and what is being done to improve their lot?

24 Hatem, 1993: 31. 


\section{EGYPTIAN WOMEN TODAY}

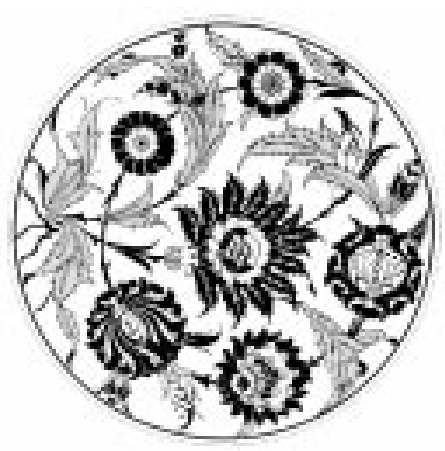

As described in the last chapter, Egyptian women have struggled throughout the century to establish their presence as full-fledged partners with men in the public sphere. Their presence outside the domestic sphere has increased as a result of numerous factors, namely education, economic necessity, and the will of the political elite; but most importantly as a result of their own efforts.

Any threat to the gains women have made constitutes a legitimate cause for concern for both women and men who believe that the wellbeing of society cannot be achieved or maintained through politics of exclusion. Consequently, while the post-revolutionary government assumed a comprehensive transformation that would encompass women, it has been noted that women's liberation has never come to assume the primacy of political or economic liberation. Women's particular concerns have been, and continue to be, subordinate to those of society, the nation, and development. Also, Egyptian men like their counterparts in the West have resisted the process of redefining gender roles and allowing women more equity. ${ }^{125}$

The growing presence of women in the public sphere has not been paralleled by more equity. In her description of their condition, Elizabeth Fernea notes that the large number of university graduates among Egyptian women, their increased presence in the public sphere, the fact that they have come to occupy top positions in the economy and in the state apparatus, are contradicted by high rates of illiteracy, minimal political participation, declining representation in parliament, and the recurrence of modest dress. ${ }^{126}$

In this monograph we argue that these contradictions are part of the current dilemma women face. Their progress toward equity is countered by a public discourse that hampers their cause. Their resistance is manifested in the various coping mechanisms they use to maintain and expand their space within both the private and the public spheres. The efforts of organizations women have formed or joined, and in the discourses these organizations are creating, have also made this apparent (see chapter V: Strategies of Resistance).

A brief review of the current status of Egyptian women will contextualize our discussion of the present public discourse, with its legitimation of a retreat from gender equity. Comparing women's past struggles and strides toward more effective representation in the public sphere with their present condition confirms our contention that there has been a loss of momentum in the advancement of their cause.

25 Hatem, 1993: 29-47.

126 Fernea, 1998: 240-241. 


\section{A. WOMEN AND EDUCATION}

Comparing older women and todays' young girls, women have achieved considerable headway in the field of education. The Egyptian Constitution recognizes the right to free education for both males and females. Despite official commitment to the education of the general population and years of investment, disparities remain between the educational status of boys and girls. While nearly 90 percent of children aged 8 to 11 are currently in school, girls' enrollment lays behind that of boys. For every 100 boys enrolled in primary school, only 84 girls enrolled. ${ }^{127}$ These inequalities are more pronounced in rural areas, with fully one-third of 10 year old girls not enrolled in rural Upper Egypt. ${ }^{128}$

Comparing male and female illiteracy levels for all ages nationwide, we find a significantly greater proportion of women are illiterate $(62 \%$ among females as opposed to $38 \%$ for males, a difference of slightly more than $24 \%) .{ }^{129}$ A comparison of these percentages with those of the first half of the 20th century reveals that the ratio of female to male illiteracy is presently higher than it has ever been before. In 1925 illiteracy among women was 96 percent (men 78\%); 1930, 95 percent (men 76\%); 1940, 92 percent (men 73\%); 1945, 90 percent (men 68\%); 1950, 87 percent (men 63\%). ${ }^{130}$ The main reasons given for the gender gap in literacy are failure to enroll in school and school drop-out. And while drops out rates are reportedly higher for boys than for girls, they remain alarmingly high for both genders, especially at the primary level. ${ }^{131}$

Once in school, girls do well. However, economic conditions and the insufficient value placed on girls' education continue to limit their attainment. Many parents refrain from sending their daughters to school at all because the perceived economic returns do not outway the costs (real and opportunity) of investing in girls' education. In addition, once in school, boys and girls receive education in different topics. For example, girls are taught home economics while boys are taught agricultural economics, topics that are considered gender-appropriate. Moreover, the study indicates that while the gender-based dichotomy within the educational system had been the subject of heated public debate earlier in the century, this issue has not yet been fully resolved. Women's domesticity is still promoted by the official curriulum. ${ }^{132}$

Massive population growth during the second half of the century and rural-to-urban migration are two factors that account for much of the difference in educational attainment between genders. The development of Cairo's infrastructure and services did not proceed on a par with the increase in demand. One study on the educational status of women in Egypt concludes that quantitative and qualitative shortages of schools are main reasons behind girls' low participation in education. Not only is there a shortage and an unbalanced distribution of schools among governorates, but in some communities, the lack of single-sex schools discourages traditionally-minded parents from sending their daughters to school or allowing them to continue if single-sex schools are not available once they reach puberty. ${ }^{133}$ Furthermore, the influx of migrants from rural areas into the city has resulted in the importation of rural values and norms into city life.

National NGO Committee, 1994: 30.

28 El-Tawila et al. 1999

129 Ibid:.30.

130 Reid 1997 as quoted in Badran, 1996.

$31 \quad$ El Baradei, 1996.

${ }_{132}$ Wassef, H, 1996, vol. 2: 330-331.

${ }^{133}$ El Baradei, 1996. 
As noted in the previous chapter, the large number of female university graduates at present is due to the commitment of the post-1952 revolutionary government to the education of the general population, part of Nasser's modernization efforts. The policies instituted during the 1950s have enabled large numbers of women and men to obtain university degrees. By the 1980's, one-quarter of all those with higher education degrees were women. ${ }^{134}$ The figure is now closer to one half.

Today, it is the effect of those very same policies, rather than a growing appreciation of women's potential, that continues to work in favor of women's education. The rising conservatism in Egypt today is at play in changing the nature of the commitment to girls' education. Education, in this trend, is valued insofar as it enhances women's roles as wives and mothers, an attitude that is reflected in the official school curriculum ${ }^{135}$. Moreover, education is important because it is a tool enabling women to fend for themselves in the public sphere if the need arises.

The parallel between the justification for girls' education presented by the contemporary conservative trend and that presented by the early women's movement in the 1920s is striking. In both cases, education has been harnessed to what feminist scholars have termed "the cult of domesticity." ${ }^{\prime 136}$ Moreover, as we shall proceed to argue, domesticity was then part of nationalist efforts-it is now part of the Islamist effort.

\section{B. WOMEN AND THE MEDIA}

The image of women in the media is indicative of the values and norms that are woven into the Egyptian social fabric. As presented in the media, women as mothers, wives, and daughters are in need of protection, the provision of which is incumbent upon their fathers, husbands, and brothers. In exchange for such protection, women are required to submit to male authority. A woman's rebellion against such submission is portrayed as deviance, which must be both repented and 'paid for,' or as an indication of women's capricious and fickle nature. In the meantime, the man is portrayed as wise, compassionate, generous, and knowledgeable about what is best for his women (harimuh). ${ }^{137}$

Another image that emphasizes the inequality between genders is the portrayal of a sexual infidelity in marriage. A husband's infidelity is portrayed as a temporary aberration, while a wife's unfaithfulness is portrayed as a crime. Accordingly, a wise wife waits for her husband to return to his senses. Her patience and compassion are rewarded by her husband's repentance and return to the fold. The image of the dignified matriarch whose triumph resides in having kept the family together has become a classical representation in the Egyptian media.

In contrast to the image of a patient, long-suffering wife is that of the outraged husband who is expected to react swiftly to his wife's adultery. ${ }^{138}$ As a consequence of her behavior, the adulteress is shown to spend the remainder of her life paying for her crime, and is often shown to have compromised her children's chances of marriage. The implication is that women are responsible for their own victimization, as well as that of their children. Should any ill beset her or the children, the misfortune is inevitably linked to her 'deviant' actions.

134 Fadwa El-Guindi as quoted in Ahmed, 1993: 210.

135 Refer to Wassef, H., 1996.

136 Badran, 1996: 52.

${ }^{137}$ While the possessive pronoun is used by women as well, as in "my man," it is used in a singular context, whereas men use it in the plural context to refer to all of the females in his household. The harem as a separate area of the house where women were secluded no longer exists. Continued usage of the term refers to women's status as dependents.

138 Repudiation through divorce and depriving the adulteress of the custody of her children is the normal course of action. Killing her in the emotional heat of the moment (so-called honor killings) is considered by the law and society at large to be an excusable action undertaken under extenuating circumstances. 
Linked to this image is that of the precarious situation of a woman without a man. A woman alone is pitied because she has no one to stand for her or back her (dahr). The term waleya (dependent) is used to emphasize the inherent vulnerability of women, which is increased if she does not have a guardian (wali) to take care of her. This protection theme is constantly disseminated by the media.

In a culture that is skeptical about women's ascendance onto male-dominated planes, women's success is also a matter of bemusement. Working women are portrayed in the media as somewhat masculine and their husbands as deprived of the warmth and tenderness they would normally expect from a wife who has no professional occupation or ambition. This is depicted in the Arabic film produced in the 1960s, Meraty Mudir 'Am (My Wife is a General Manager), a comedy starring Salah Zulfikar and Shadia. Zulfikar plays the role of

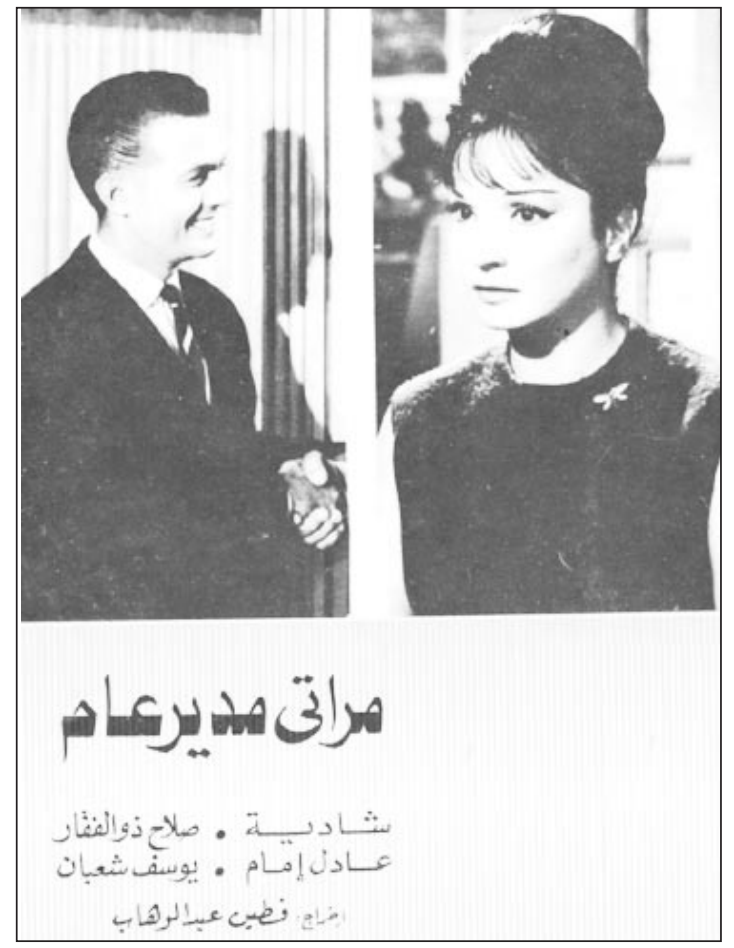

A POSTER OF THE FILM "MY WIFE IS A GENERAL MANGER". an employee working under the supervision of his wife. Although the movie ends with Zulfikar's willing acceptance of his wife's well deserved seniority, her executive looks are portrayed as somewhat lacking in femininity while his exasperation with this 'unusual' situation seems endearing.

Recent films do not differ much in their portrayal of women professionals. Busy pursuing their careers, female professionals are blamed for any family or conjugal mishap. Moreover, the film Istiqalet Alemat Zara (The Resignation of a Nuclear Physicist) is but another example of the media stressing the inability of women to combine career and family. Soheir ElBably, portraying a respected nuclear physicist, is a stickler for punctuality and professional standards. However, as soon as she discovers she is pregnant, she rethinks her priorities and consequently starts neglecting her work.

The stereotyping that prevails in the mass media is legitimated by reference to essentialist arguments. Because of their biological constitution, women are argued to be emotional and erratic. They are fragile, superficial beings who care only about appearances. These are but a few examples of the type of images disseminated by the media. ${ }^{139}$

Studies on the impact of stereotyping indicate that women do not identify with the images portrayed by the media, and that their creativity and interaction with society is hindered by the values it promotes. Moreover, the inadequacy women feel as a result of not identifying with the images has been linked to their receptiveness to conservative ideologies. A significant segment of middle class women find the traditional role models of mother and wife more appealing than the more complex reality of professional women who might also be wives and mothers. ${ }^{142}$

\footnotetext{
139 For an extensive discussion of the image of women in the Egyptian media, refer to Abdel Kader, 1982.

${ }_{140}$ For more on the issue of stereotyping, refer to Elsadda, 1997a.
} 


\section{WOMEN AND WORK}

Arab countries have some of the world's lowest female labor force rates. Traditionally, men have been responsible for the economic support of their families, and only a minority of very poor or very wealthy women were economically active in the public sphere. After the 1952 revolution, however, opportunities opened up for women, allowing them more space in the public sphere. Nevertheless, for a number of reasons, including male unemployment women's participation in the labor market has remained modest. The percent of women in the labor force in Egypt has risen somewhat over the last decade, in 1995 the percent working for wages (not familly workers) stood at $21 \%$ of urban women, $11 \%$ of rural women. ${ }^{141}$

Article 14 of the Constitution of $1971^{142}$ gives all citizens equal access to public employment irrespective of gender. Law 137 of 1981 allows women to work at night in hotels, theaters, and airports as long as adequate protection is provided (a rather ambiguous clause that is largely ignored). Despite such increases in women's labor force participation, women's average wages are approximately one-third lower than those of men. On the whole, women hardly ever reach leadership positions, and when they do, the occurrence is viewed as an anomaly. Moreover, women's representation in labor unions remains insignificant; only 621 women belong to labor unions compared to 17,441 men. ${ }^{143}$ This suggests that women do not perceive unions as beneficial to their interests.

Women's business initiative and acumen are constrained by their entrenchment in the domestic sphere, restrictions on their mobility, and by their lack of exposure to information about loans and training opportunities. Consequently, small, traditional, home-based enterprises are often women's only alternatives. This is especially true among women from the middle and lower socioeconomic strata who, instead of reallocating the income from these enterprises to the expansion or upgrading of the business, are often required to use it for household and other emergency purposes. Moreover, the skepticism surrounding women's business abilities often works as a deterrent to their entrepreneurship.

The discouragement of women's economic role is legitimated by the prevailing value system and associated norms. These values and norms denigrate women's labor and contrast it to women's domesticity, which is generally commended and even, in the case of the Islamists, sublimed. The perpetuation of the image of the house as a woman's kingdom is part of the resistance of society to women's emancipation. Moreover, women who have ventured in the public sphere have often been blamed for much of the violence inflicted upon them, both in the work place and on the street, while domesticity has been presented as the way for women to preserve their dignity.

Women are also subjected to other difficulties that further their isolation from the public sphere. Working hours that are incompatible with family obligations and inappropriate modes of transportation are among the many factors that women encounter both in private and in public sector employment. The letter cited below, from female government employees, illustrates the institutional obliviousness to the multiplicity of roles that women play:

El Safty, 1995.

142 Egyptian Constitution, 1971.

${ }_{143}$ Nassar, 1996b. 
By Force...Not By Choice: It is true that the evening shift at the Registry office is optional and not mandatory, yet this is only in theory. The reality is somewhat different. Women represent approximately $80 \%$ of all employees at the Registry; consequently, whoever refuses to work in the evening is deprived of the additional income which is in fact a major source of income for most of us. Moreover, the way the shifts are organized from 8:00 am to 2:00 pm, and from 5:00 $\mathrm{pm}$ to 8:00 pm make it impossible for us to go home and come back. Most of us live in remote areas, and the traffic does not help. By the time we go home, it is already time to leave for work. What about our children? How are they supposed to fare during our absence. We would prefer to work one long shift from 8:00 am till 4:00 or 5:00 pm so that we can fulfill our obligations both at work and at home. We hope that the Minister of Justice will understand our conditions and that he will be receptive to our suggestions. (signed by: Tortured employees of the Registry). ${ }^{144}$

A study by Nassar on the employment status of women in Egypt shows that men's occupational structure is more evenly distributed than that of women. Women work in a limited number of occupations at all levels of the occupational ladder. Moreover, unemployment among women is widespread, and higher than it is among men, and the duration of their unemployment is longer. ${ }^{145}$ Given the concentration of women in the government sector, MacLeod notes that women are bound to be more negatively affected than men by the government's retreat from its role as a main employer. ${ }^{146}$

Gender-based discrimination even extends to child labor. A study conducted by Nadia Farah Ramsis for UNICEF revealed that only 22 percent of female child workers are paid, as opposed to 58 percent of their male counterparts. ${ }^{147}$ This is largely because girls are more likely to work in family enterprises, especially agricultural ones.

\section{WOMEN AND POLITICAL PARTICIPATION}

Political participation and representation are issues of concern for Egyptians regardless of gender. The apathy characterizing participation in the Egyptian political process has been noted by many scholars, but a discussion of this apathy is beyond the scope of this monograph. However, despite a general lack of political participation and representation, the situation among women is especially dismal. The marginal presence of women in Parliament has become especially evident since 1990, when the law setting a quota of seats reserved for women was declared unconstitutional. The idea that politics is a male preserve is inculcated into women from childhood and throughout adolescence, via a conservative discourse that portrays different roles and obligations for each gender.

While the 1956 Constitution asserts equality between women and men in the exercise of their political rights, women's registration to vote in electoral ballots is optional while men's is obligatory. In the mid 1990's the level of women's registration remained less than 10 percent. ${ }^{148}$ The actual participation of women in Parliamentary elections was only 6 percent in $1990 .{ }^{149}$

\footnotetext{
Al Ahram, November 5, 1997 (author's translation).

Nassar, 1996b.

146 Macleod, 1991: 8.

147 Farah, 1997.

148 Ibid: 412.

149 Gomaa, 1996: 74.
} 
Family opposition, limited knowledge of the law, and scarce resources combine to discourage women from entering the political arena. A research project based on case studies of women parliamentarians indicated that family support has been a crucial factor in determining the course of their political careers..$^{150}$ These women however, are exceptions. The political game is a dirty and rough one, in which men-as the supposed stronger species-are more apt to engage.

Further, when campaigning in elections, women's effectiveness is limited as they tend to abstain from raising or engaging in debates related to gender issues for fear of compromising their chances of being elected. The reluctance of political parties to support women from their own ranks also restricts women's candidacy in elections. ${ }^{151}$ Awareness of the constraints to women's political participation has prompted the formulation of a program of action to enhance their participation in decisionmaking processes. A workshop was held prior to the 1995 elections in order to formulate an electoral program for Egyptian women.

One survey of action-oriented interventions designed to enhance the socioeconomic status of Egyptian women recommended that a center for supporting women candidates be established. It also recommended that the laws affecting women's political participation be revised, and that women be trained in leadership skills in order to serve as leaders for poor communities. ${ }^{152}$ The Huda Project, initiated by the Ibn Khaldoun Center for Development Studies in 1995, is designed to provide women with such support.

\section{E. WOMEN AND THE LAW}

Another area in which women have not been treated equitably is the law. While contention has been strongest regarding the family and nationality laws, women are also short-changed in the penal code. Though much of the discrimination that takes place is due to the interpretation of the text and its application, which are left to the discretion of a predominantly male judicial body, there is also a differentiation between genders in the body of the text. A notable example is the difference in the penalty for the murder of one's spouse upon discovery of adultery. Whereas men are given a light prison sentence (not more than three years) for murdering their adulterous wives, women are often sentenced to hard labor for life for murdering their unfaithful husbands. This difference is justified by the widespread attitude that a man's honor is dependent upon his wife's virtue. Consequently, his violent reaction to his wife's adultery becomes excusable, especially if committed in the heat of the moment. ${ }^{153}$

The interpretation of the text also presents problems. Although rape itself is penalized, forced or non-consensual marital intercourse is not considered by the law to constitute a criminal offense. However, a study conducted by the New Women Research Centre and El-Nadim Centre found that 93 percent of the women in the sample considered intercourse under such conditions as rape. The fact that 46 percent of the men in the sample said they are entitled to force their wives into intercourse reveals the discrepancy between their world view and that of women. ${ }^{154}$

The penal code is also applied differentially by gender. In cases of spousal battering, the punishment is usually harsher for a woman who beats her husband than for a husband who beats his

\footnotetext{
This research project is an initiative of the Ibn Khaldoun Center for Development Studies.

Shukrallah, 1997.

Nassar, 1996a.

53 National NGO Committee, 1994: 37.

154 El-Nadim Centre and New Woman Research Centre, 1994: 38-39.
} 
wife. By law, husbands are entitled to physically punish their wives in case of disobedience (ma'sseya) so long as no permanent damage is inflicted, yet women are not allowed similar provisions. The difference in penalties exacted from each gender reflects the preeminence of a value system in which the purity of women is assigned utmost importance, and men's sexual latitude is indulged. Moreover, the supremacy (qawama) of men over women is accepted with varying degrees among Egyptians of both genders. For example, the 1995 Egyptian Demographic and Health Survey found that a not insignificant number of women, especially among lower and middle income women and those residing in rural areas, believed that wife beating was justified under certain circumstances. ${ }^{155}$

Also contentious is the nationality law. Law 26 of 1975 stipulates that an Egyptian woman married to a non-Egyptian man cannot confer her nationality onto their offspring, yet if the father is unknown, the children are registered as Egyptian citizens. Men do not face the same problems. Non-Egyptian wives can apply for Egyptian nationality two years after marriage, and their children are automatically registered as Egyptian citizens at birth, regardless of their mother's nationality. The social, political, and economic implications of this law extend far beyond the blatant differentiation between men and women. One implication is that the offspring of Egyptian mothers married to non-Egyptians are deprived of all the rights and privileges of Egyptian citizens. They cannot vote, serve in the army, or be employed in the government. They are required to obtain residence visas and work permits. They register at schools and universities as foreigners and consequently pay fees that are much higher than they would otherwise pay as Egyptians. The economic burden that this law entails is often shouldered by the mother who is forced to resort to extreme measures to bear the costs involved. Moreover, the 'preventive' and hence 'protective' aspects of the law are emphasized and presented as justifications for the persistence of discrimination. ${ }^{156}$

Suggestions for reform remain unheeded. Consequently, the nationality law remains a main item on the agenda of Egyptian feminists, together with the Personal Status Law. Despite decades of active lobbying, the government has resisted changes in the personal status law, so much so that the law has been described as the ultimate " bastion of control."157

\section{F. WOMEN AND HEALTH}

Education, employment, and socioeconomic status are all determinants of health. Given the generalized disparity between genders, one would also expect to find disparites in the health status of men and women. This is indeed the case. These disparities are more visible in rural areas than in urban settings, and are compounded by social values and norms that impart added value to the life of men.

Research indicates that while there are biological factors accounting for the health problems affecting women, a strong social dimension is also present. Despite growing opportunities for education and decreases in infant mortality rates, the birth of a boy remains a source of greater happiness and pride than that of a girl. This sentiment pursues women throughout their life cycle. Families of lower socioeconomic status, and especially in rural areas, lavish less attention and health care on their daughters than they do on their sons. ${ }^{158}$

55 El-Zanaty et al. 1996: 206

156 For further information, refer to Wassef, N, 1997.

157 Badran, 1996: 124.

158 El-Hamamsy, 1994. 
The predominant norm that encourages women's domesticity and motherhood has tremendous implications for their physical and psychological health. It perpetuates a pattern of early marriage and reproduction that is detrimental to both the woman's and the infant's health. ${ }^{159}$ Early marriage also endangers women's lives, in several ways. First, women who marry early are exposed to the risks of pregnancy and childbirth for longer periods of time; this is especially problematic in countries like Egypt that have high maternal mortality rates. Moreover, although statistics on maternal mortality are notoriously inaccurate, younger women face higher risks of dying during pregnancy and childbirth than older women. Furthermore, a longer reproductive life increases the risk of unwanted pregnancy, which a woman could choose to terminate in an abortion, a risky undertaking because of its illegality in Egypt (except for those women whose lives are endangered by the pregnancy). Women are forced to resort to clandestine procedures, which pose serious health risks or even result in death (deaths that are usually underreported). According to a study on the quality of reproductive health care services, 46 percent of abortions in Egypt are performed in 'back alley' clinics. ${ }^{160}$ Research also indicates that children born to mothers under age 20 are more likely to die than children born to older mothers. ${ }^{161}$ A thorough discussion of such increased risks is beyond the scope of this monograph. However, in addition to the likelihood of being physically immature themselves, young mothers in Egypt today are more likely to have come from disadvantaged backgrounds and suffer from accumulated health conditions such as stunting. In addition to these physiological issues, young mothers tend to have shorter intervals between births than older mothers, thus placing subsequent children at greater risk of death. Moreover, women who marry early tend to curtail their education, thereby limiting their access to crucial health and hygiene information that could offset these other disadvantages. ${ }^{162}$ Additional factors working against women's health are cultural norms that encourage women to put their families' needs ahead of their own and to neglect their own health problems. "Silent endurance" is a cultural norm for women that results in much of the inequity women bear. ${ }^{163}$

Women in Egypt are also subjected to female circumcision, often called female genital mutilation (FGM). In Egypt, this procedure typically involves the partial excision of the external genitalia. Despite having adverse effects on women's health, the practice is almost universal among ever-married Egyptian women. ${ }^{164}$ It also enjoys a high level of support among Egyptian women, especially among non-working women and those residing in rural and urban slum areas, who believe it to be a "good tradition" with many benefits. ${ }^{165}$

Restricting women's options entails limiting their effective participation in society. Moreover, confining women's domain to the private sphere has implications that extend beyond their exclusion from the public sphere. Women's health, general wellbeing, and even their nurturing capabilities are diminished by the lack of exposure that such confinement entails. This reality is both reflected and reinforced in the public discourse. The dominance of the theme of women's domesticity in this discourse reveals, as we shall discuss in the next chapter, the imperviousness of a predominantly male-dominated ideology to women's interests and concerns.

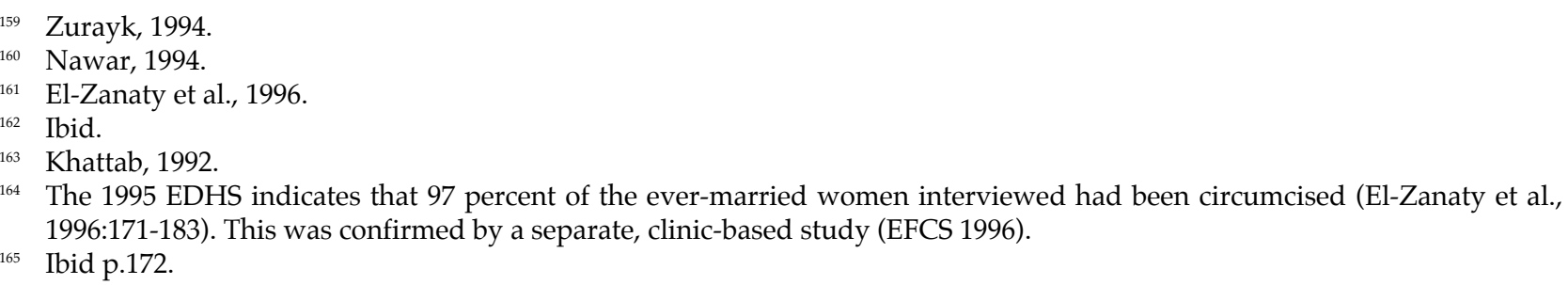




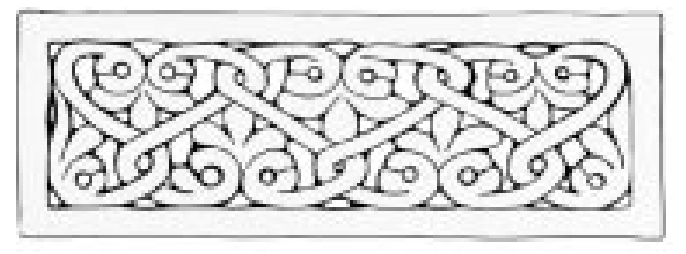

In order to grasp the significance of the conservatism, which we contend permeates the prevailing Egyptian discourse, it is important to identify the focal theme of this discourse. Our contention is that equity was the focal theme of the transformation that was supposed to have taken place after independence, and that half a century later it remains the problematic of the development process. Gender-equity is just one of the achievements that the post-revolutionary government was supposed to have realized. However, it was never a priority for the new regime. Rather, as noted above, it was a promised trade-off for women's participation in the nationalist struggle that was later compromised once national independence was attained. The margin of liberty that was availed to women was supposed to allay what has been described as "the radicalizing consequences of women's political participation." ${ }^{166}$ The perennial relegation of women's enfranchisement to the bottom of the priority list is the result of political expediency.

Historically, whenever it has been advantageous to treat women as full-fledged partners, men have had no compunction in engaging in such a partnership. Moreover, whenever the situation warrants a closing of ranks, factional divisions are set aside, albeit temporarily, until the objective of the partnership is fulfilled. The mobilization of women during the nationalist struggle is a case in point. Both liberal and conservative men encouraged women's activism during the struggle without seeming overly disturbed by the gender dimension of such activism. However, when women's activism was perceived to no longer serve the nationalist cause, the men withdrew their support. ${ }^{167}$ In fact, it has been noted that the liberal politicians of 1919 never intended to defy the religious establishment regarding inequalities in the Sharia, as has the unwillingness of the postrevolutionary regime of 1952 to tackle these issues. ${ }^{168}$

Similarly, decades later, the status of women is expressed in a manner that does not place the (male) interlocutors, whatever their positioning on the political spectrum, on a collision course. Whereas they might stand at opposing ends on almost every issue, there is significant consensus regarding women. How else can we explain that despite the century-long efforts of individual women and women's groups, the contentious personal status and nationality laws, as well as the practice of female circumcision remain unresolved?

The reversals of Decree 44 (Jihan's law) regulating polygamy, the Minister of Education's Decree 113 of 1994 regarding the wearing of the hijab in schools, and the controversy surrounding the Minister of Health's Decree 261 of 1996 forbidding the performance of female circumcision in all state hospitals and clinics, illustrate the convergence of conservative social trends with Islamist views. These issues will be discussed in the ensuing sections.

\footnotetext{
${ }_{166}$ Hatem, 1993: 43.

167 For an account of the unity between men and women during the national struggle, refer to Badran, 1996.

168 Talhami, 1996: 1-20.
} 


\section{A. WOMEN: DIFFERENT BUT EQUALLY WORTHY}

The state's manipulation of religious symbols as a means to coopt the Islamic wave, and the polemic of both the religious establishment and the opposition have acted as catalytic forces encouraging much of the inequitable treatment of women. The fact that all debates have been carried within the framework of an Islamic context has been noted, and is reflected in the additional media space that was made available to the official religious establishment and in the infusion of religion over time into the school curricula. ${ }^{169}$

A discussion of the themes and issues that have been controversial during the past decade, and the position adopted by the state and the Islamists will substantiate our claims concerning the unfulfilled promises to women. This should not be construed to imply that women are totally absolved of the responsibility for this situation. ${ }^{170}$ Some women activists have also promoted change but in different and conflicting directions. Notable examples are Labibah Ahmed, Zeinab Al-Ghazali, and Kariman Hamzah who, despite their active presence in the public sphere, have carried forth the notion of gender distinctiveness, therefore imparting a message of gender complementarity rather than equality. These women, together with other supporters of the conservative agenda, find it necessary to emphasize the superiority of women as family nurturers. It is important to note that women's support of customs and traditions that often constrain their lives is a phenomenon that occurs in many cultures; it is neither unique to Egypt, nor to Islamic or other developing countries. ${ }^{171}$

"I chose to stay home and raise men like Khalid AlIslamboli." 172 This statement is an excerpt of an interview conducted in the 1980s with a veiled woman (Mona) who had given up her university teaching post. Staying home for her was a militant endeavor. Many other women who share this discourse have chosen to work outside their homes, but claim this to be a temporary measure until circumstances allow them to retreat from the public sphere and return to their 'natural' domain in the home. While for many the change in circumstances is tied to their economic situation, for a minority of women such as Mona, the change of circumstances entails much more comprehensive and longterm change. In a study of Zainab Al-Ghazali, Cooke notes that for such women "[T]he ideal of women's domesticitythe domain of men's rights over their women-is to be shelved until the Islamic state is restored."173

The contradiction inherent in this argument seems to escape women like Al-Ghazali. The fact that they are fighting their battle outside the private domain is justified on the same grounds that violence is condoned by a faction of

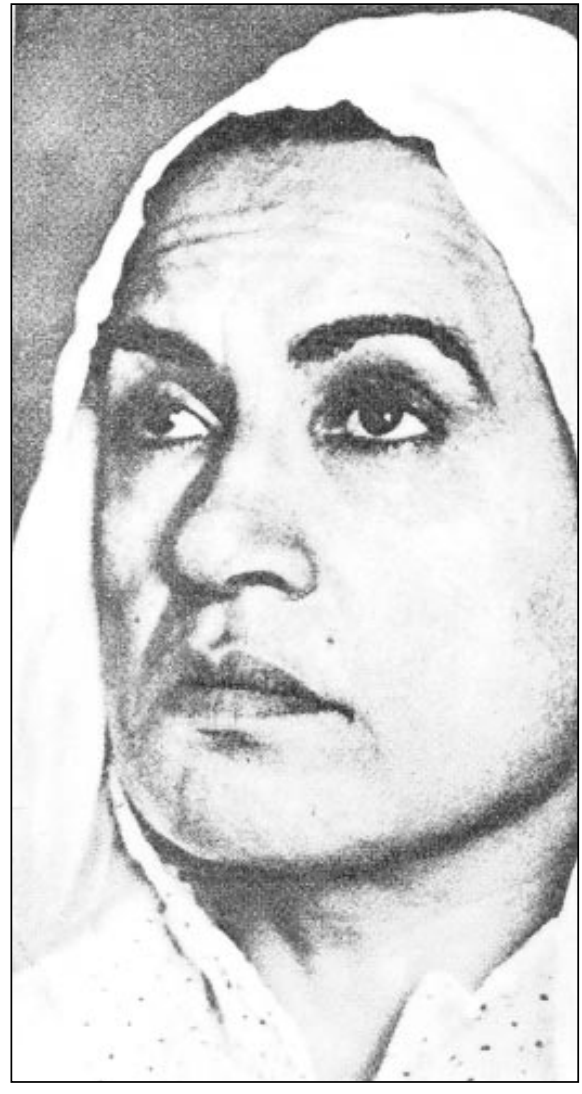

ZEINAB AL-GHAZALI

169 Ibid: 61.

170 Ibid: 1

171 Kandiyoti, 1991b.

172 Al-Islamboli is the young officer who killed president Sadat in October 1981 during the parade held in celebration of the 1973 victory against Israel.

173 Cooke, 1994: 1-20. 
Islamic activists. Being in an 'abode of war' (dar harb) justifies behavior that would not be accepted once Islamic rule, and the 'abode of peace' (dar salam), are reinstated.

Other women have adopted part of the Islamic discourse while going on with their lives and careers as usual. The fact that they have become more religiously and ritually observant and more observant of certain dictates, such as a more modest code of dress, does not entail their retreat into the private sphere. On the contrary, for some women, especially in low-income urban districts, the observance of religion in a visible manner has given them unprecedented freedom and leverage. They are allowed greater than usual access to the public sphere, in addition to becoming relatively immune to various forms of sexual harassment.

\section{B. THE PERSONAL STATUS LAW AND THE NEW MARRIAGE CONTRACT}

O mankind, we have created you male and female and appointed you races and tribes, that you may know one another $(49,13)$

This verse from the Quran has often been used to legitimate the 'complementarity of the genders.' Equality such as that sought by the amended Personal Status Law 44 of 1979 and the proposed new marriage contract have been the subject of fierce resistance from both secular and religious establishments. When President Sadat issued the presidential decree known as Law 44 (or Jihan's Law, because of support from First Lady Jihan Sadat), it was met with vehement resistance from all factions of the political spectrum. The secularists opposed it on procedural grounds because Parliamentary approval had not been secured. The religious establishment, the opposition, and other conservative forces objected to the law on the basis that it did not conform to Sharia. The main supporters of the amended law were its initiator and patron (Mrs. Sadat) and a group of feminists who celebrated it as a victory crowning their long struggle for a less discriminatory personal status law. The law did not receive adequate support from society at large, but especially from men, for a number of reasons. Most importantly, the amendments had economic implications that favored women; in addition, both men and women refused to relinquish the tradition of men's superior hold over women.

Under the amended law, a woman obtained the right to ask for a divorce on the basis of injury (darar) within one month of being officially notified of her husband's marriage to another woman. After this month, she could no longer claim injury; thus in case of divorce, she lost her rights as stipulated by law. The main advantage of the amended law was that it gave women the right to refuse being part of a polygamous relationship, without being legally and materially penalized. Prior to this amendment, women were often not notified of their husband's second marriages; and if they objected and asked for a divorce, they lost their rights to alimony and to remain in the marital home as long as they retained custody of their children, in addition to any other material compensation stipulated in the marriage contract.

The law also curtailed another practice called bayt al-ta'ah (house of obedience) (discussed previously). In order to enforce his wife's obedience, a man had had the right to call upon the authorities to enforce his wife's return to the marital home. The practice has been the cause of much controversy because it forced a woman to remain married until she could legally prove that the marital relationship could no longer be sustained. As it stands now, after the rescindment of Law 44 , the wife forfeits her right to financial support if she disobeys or fails to contest her husband's 
summons within 30 days. ${ }^{174}$

The widespread objections to Law 44 resulted in its reversal and the subsequent reinstatement in amended form as Law 100 of 1985 . The new amendment made Sharia the sole basis for personal status legislation rather than one of its bases. Thus Islamic law became the one and only frame of reference for matters pertaining to personal status.

The idea of the new marriage contract was born in the mid-1980s; however, due to opposition, it has not yet come into effect. ${ }^{175}$ Apart from requiring a medical examination before marriage, the new contract contains no compulsory clauses. Aspiring to more equity within the institution of marriage, this new contract provides a checklist, which includes many issues. The existing marriage contract allows for the inclusion of conditions agreed upon by the partners; however, the fact that it does not include a checklist intimidates women and discourages them from establishing themselves on a more equal footing within marriage. For example, among the most contentious issues of the new marriage contract is that it allows both spouses the right to divorce ('esma). Other possible clauses relate to ownership of the furniture and conjugal home, as well as the right to education and travel. The new marriage contract has been decried under the pretext that it would lead to the disintegration of the family and an increasing number of divorces. A wellknown proverb is often cited in rebuttal to the proposed contract: "Al-markeb eli leha rayessin teghraq" ("A ship with two captains sinks").

Most vocal women's organizations in Egypt (refer to chapter V: Strategies of Resistance) focus on research, monitoring, advocacy, counseling and service provision. The effectiveness of their work on the ground is limited due to legal, as well as institutional constraints. Law 32 of 1964, which regulates associations, has been criticized for restricting the ability of NGOs to address community concerns because excessive regulations that limit their ability to act in a timely manner. ${ }^{176}$ For example, while religious NGOs have the freedom to mobilize funds through alms (zakat), non-religion based NGOs are not allowed to solicit funds unless they obtain special permission to do so from the Ministry of Social Affairs. ${ }^{177}$

Opposition to reform of the Personal Status Law and the marriage contract is embedded in ignorance of the law, as well as in conservatism. For example, most Egyptians do not know that the existing marriage contract does not oppose the inclusion of provisions such as sharing the right to divorce. Moreover, practices that the proposed changes were designed to curtail are justified in a patronizing manner. The gist of such justifications is that protection of women, family, and society are incumbent on men and that polygamy, bayt al-ta'ah, and male monopoly over the right to divorce are mechanisms that enable them to fulfill this obligation.

Resistance to Law 44 took many forms. While some were able to vocalize their opposition, the majority expressed their standpoint by circumventing of the law (men) or by choosing not to exercise their rights (women). For example, some men avoided notifying their wives of their second marriages, and some women, upon being informed of their husband's second marriages, chose not to exercise their legal rights. For these men and women, the social ramifications of the proposed amendments were as contentious as the economic ones.

\footnotetext{
Zulfikar, 1995

For a detailed discussion of the new marriage contract, refer to Chapter 5 of Zulficar, 1995.

176 Ibrahim, 1996.

177 For a discussion of the private voluntary organization (PVO) sector in Egypt, refer to Sullivan, 1994; Latowski, 1995; and Kandil, 1995.
} 
The conservative tendencies of the Egyptian middle class have been explained as the result of their exposure to rigid interpretations of Islam, either directly through migration to the oil-producing Gulf countries during the late 1960s and the 1970s, or indirectly through contact with returning migrants. Consequently, the manner in which opposition to Law 44 and to the new marriage contract was expressed can be said to reflect the changed circumstances and world view of the middle class. ${ }^{178}$

This conservatism of the middle class is accompanied by a focus on gender relations and sexuality. In her study of politics in Cairo's popular quarters, Singerman explains the centrality of gender issues and sexuality in the prevailing discourse as a reflection of the confrontation between secular and religious ideologies. Singerman describes the way sexuality has been used by the Islamists to justify their claims to legitimacy, giving as an example a wave of rapes in 1985 that they claimed was the result of the unbridled contact between men and women. ${ }^{179}$

Moreover, the state has also used gender relations and sexuality to discredit the Islamists. For example, the state-controlled press has described how Islamists lure young girls and women away from their families and husbands for marriage. These unofficial (urfi) marriages have been criticized and declared invalid because of the element of furtiveness. According to Sharia, a marriage is only valid if it is openly declared ('alani). And, while the protection of women and the family have been cited in the argument against contracting an urfi marriage, the state has been unwilling to challenge such a marriage on the basis that it is religiously legal.

The unwillingness of the state to challenge the premises upon which much of the Islamist discourse on women is based is apparent in the way that the public discourse is managed and in the messages that are disseminated through the media. State policies are promoted through the same channels that fail to educate the public about the legal and social ramifications of the actual and proposed family law and Personal Status Law. Moreover, the most common misconceptions regarding gender relations and roles are perpetuated through media representations that are allowed to exist virtually unchallenged, once again confirming our argument that there are grounds of agreement between the state and the Islamists.

\section{ISLAMIC ATTIRE AND THE NEW VEIL}

O Prophet tell thy wives and thy daughters and the women of the believers to draw their cloaks close round them. That will be better, that so they may be recognized and not be annoyed. Allah is ever Forgiving, Merciful $(33,59)$

The veil has been a contested symbol and focus of controversy. In the first half of this century the veil was seen as a symbol of women's subordination. Its removal has come to symbolize their emancipation and the demise of the harem. However, a new headcover appeared following the 1967 Arab-Israeli war, one that is different from that traditionally donned by women in rural areas and in popular quarters of Cairo, one that holds no ideological significance. The traditional veil reflected the polarization of genders, the new veil, part of the actual Islamic attire (al-ziy al-Islami), amplifies the schism between Muslims and Christians; but more so the divide between Islamists

\footnotetext{
78 Kandil, 1995: 40-41.

179 Singerman, 1997.
} 
and 'secularists.' The former being perceived by a sizeable segment of the population as role models (qudwa), and the latter as deviants (munharifin). This new polarization has led to protracted confrontations and numerous incidents of violence involving Muslims and Christians and Islamic militants and civilians. ${ }^{180}$ While reported incidents such as the throwing of acid at unveiled women are rare, women are undeniably bearing the brunt of the tension created by these divisions. The fact that women who have chosen not to wear the Islamic attire are nevertheless dressing in a more conservative manner than they did in the 1960s and 1970s is a reflection of the pressure they feel to conform to Islamic norms.

Appearing in the mid-1970s, the headcover now referred to as hijab, khimar, or niqab (depending on the extent of covering) was first worn by university students. Although it caused a certain amount of friction between these students and faculty members, it nevertheless prevailed thanks to the efforts exerted by Islamists both on and off campus. The ensuing years witnessed an increase in the popularity of Islamic attire to include employees in government offices and schools. Various reasons have been advanced to explain the popularity of this attire; some argue that it blurs distinctions based on class or wealth, and others have argued that it increases women's access to public space. Some also suggest that those who wear it do so to make a statement, to separate themselves (the 'true believers') from the rest of society. ${ }^{181}$

The Minister of Education's Decree 113 of 1994, stipulating that girls could only wear the headcover at school if parental consent was obtained, has brought upon him the wrath of conservative forces from both within and outside of the system. The decree was precipitated by an incident at Qasim Amin School for Girls, in which a headmistress forbade unveiled girls from attending school. ${ }^{182}$ Examining the content of mainstream media coverage, it is clear that public opinion was divided between those who deplored the undemocratic attitude of the headmistress and those who defended her under the pretext that her aim was to protect the students from harassment in the street on their way to or from school. ${ }^{183}$

A public debate ensued on the appropriate dress code for women in the work place, especially for employees of religious establishments and affiliated institutions. The Islamic press mounted an attack on the Ministry of Religious Endowments (awqaf) because it employed unveiled women. The gist of the diatribes was that their laxity in enforcing the Islamic attire was unforgivable, since Islamic institutions should be role models for the rest of society. The Ministry was apologetic and focused its response on the fact that the law did not allow the enforcement of any dress code. In addition, a number of unveiled employees were cited explaining that they did not cover their heads because their husbands had threatened them with divorce if they did so. Finally, Ministry officials argued against forcing women to don a headcover that they would only shed upon leaving work, asserting that convincing women of the importance of being properly attired would prove worthier in the long run. ${ }^{184}$

The significance of the veil or Islamic headcover in relation to gender equilibrium was not focal to this discussion, which lasted until 1994 when the decree was reversed and declared illegal on

180 The Ibn Khaldoun Center for Development Studies reports a death toll of approximately 2,000 during the past ten years. These fatalities occurred among civilians, both Christians and Muslims; and in confrontations between security forces and militant Islamists.

181 Talhami, 1996: 55.

182 It is ironic that this event occurred in a school named after the man who, in the 19th century, called for the unveiling of women.

183 "Akher Iftera'at Wazir al Talim ...Al Hijab Horeya Shakhseya" (The Minister of Education's most recent allegation...Donning the hijab is a matter of personal choice), 1992.

${ }_{184}$ "Al Jeans Fi Wezarat Al Awqaf!" (Jeans in the Ministry of Religious Endowments!), 1991. 
procedural grounds. Throughout the discussion, the conservative polemic prevailed. The Islamic dress code was portrayed as a protective shield for self-respecting women. This implied that unveiled women are not worthy of such sentiment; but, more importantly that they are responsible for the aggression perpetrated against them. In contrast, men's responsibility for acts of aggression was rendered secondary to that of ensuring that the women of their households were properly attired. It is very important to realize the impact that this discourse has on women who choose not to conform to the Islamic dress code, identifying them as legitimate targets for violence.

The repercussions of these messages extend beyond the infringement on liberty of dress to include various forms of harassment and discrimination against women. The example of the Qasim Amin school is a case in point. The reversal of the Minister's decree lays the ground for discrimination against unveiled girls by school staff. The perception of these girls as morally lax, and hence deserving of punishment or unworthy of protection, is also extended to their families. Such perception is legitimated by the fact that the decree was reversed by court order.

The harassment of women is often the result of a focus on their sexuality. The words used to describe the unveiling women (sufur; tabarug; fitna) translate as unveiling, adorning, and seducing is indicative of their representation as sexual objects. Holding them responsible for their victimization is furthered through the propagation of imageries of debauchery and decadence. It is interesting that the word fitna is also translated as sedition, thereby implicating women in the disintegration of Islamic society while men are absolved from a significant measure of responsibility.

While the image of women is predominantly male-defined, women have participated in shaping it. A notable example is the article published in 1988 by Nefissa Abed in the weekly mainstream magazine October. In the course of refuting the argument of a woman professor who dared speak against the veil, the author listed the body parts that an unveiled woman exposes, and described such nakedness as "an open invitation to human flies" (tabaq makshuf li zobab el bashar). This image was juxtaposed with one that the author concluded was most romantic, which is that of the veiled woman who keeps her beauty for one man, her husband. ${ }^{185}$

This type of rhetoric, which calls attention to women only as sexual beings, is part of what the feminist movement is attempting to change through its strategies of resistance. The Women and Memory Forum, an Egyptian NGO described in detail in Chapter V, is an example. By revisiting traditional Arabic texts and revealing women's contribution to shaping the history and culture of their society, the Forum is attempting to change women's self-perception, as well as educating society at large regarding gender issues.

Exposing the many ways in which women are used to further purposes and causes other than their own is another part of the struggle that feminists have undertaken. Noting that "no single issue defined the Islamic way of life more than women," the bringing of the veil into the public discourse has been explained as expressing the reassertion of the superiority of Islamic values over Western ones. ${ }^{186}$ The uneasiness characterizing the transition from traditionalism to modernism is reflected in a rejection of many of the ideas and norms associated with the West. This rejection is based on the premise that in their focus on 'progress' after attaining independence, Islamic countries rushed blindly to emulate the West, to the detriment of their own civilization and cultural ethos. Yet, rejection of the West is not wholesale, even among the most entrenched of traditionalists. Rather, most traditionalists think that Islamic countries should be more selective, 
adopting only those aspects of Western civilization that are useful and conform with Islamic values. As expected, the controversy surrounding this view results from the absence of a consensus on the definition of what is useful and in conformity with Islamic values.

\section{THE INTERNATIONAL CONFERENCE ON POPULATION AND DEVELOPMENT}

Say: Come I will recite unto you that which your Lord hath made a sacred duty for you: that ye ascribe no thing as partner unto Him and that ye do good to parents, and that ye slay not your children because of penury - We provide for you and for them - And that ye draw not night to lewd things whether opened or concealed. And that ye slay not the life which Allah hath made sacred, save in the course of justice. This He hath commanded you, in order that ye may discern. $(7,152)$

When the United Nations International Conference on Population and Development (ICPD) ended in 1994 and was declared successful, there was a general mood of relief. Many observers had doubted the possibility and wisdom of holding it in Egypt after the virulent campaigns that both the Islamists and factions within Al-Azhar University had mounted against it. In response to these widespread concerns, the government had gone overboard confirming its commitment to holding the conference as planned and issuing reassurances about security measures.

Although the idea of the conference as a whole was decried by the most extreme factions of the Islamists who described it as a conspiracy among industrialized nations against developing nations, and especially Islamic ones, the mainstream criticism was leveled against three main items on the conference agenda. These were contraception, abortion, and female circumcision.

It is interesting to note that the Islamists' arguments against contraception specifically counter those that have been put forward in the West in its favor. The freedom to decide whether or not to have children is perceived as giving human beings power that really belongs to God. The consequences of such usurpation of this power are moral and social decadence, and eventual annihilation. Therefore according to the Islamists, population control is a non-issue. Poverty exists everywhere, even in countries that do not have an overpopulation problem. Poverty is perceived to result from mismanagement of resources, corruption, and the adoption of consumerist values. The eradication of poverty, they argue, is dependent on the coupling of increased productivity with Islamic values.

Birth spacing (tanzim) on the other hand, is allowed by the Islamists, who cite the following verse of the Quran to substantiate that a two-year period between births:

Mothers shall suckle their children for two whole years (that is) for those who wish to complete the suckling. The duty of feeding and clothing the nursing mothers in a seemly manner is upon the father of the child. No one should be charged beyond his capacity. $(2,233)$

The above verse has been interpreted as allowing for a period of two years between each child. A closer look at the implications for women of favoring birth spacing over limitation reveals a situation whereby early marriage and lengthy reproductive lives result in numerious pregnancies for most women. Even if women do not bear their pregnancies to term, their health could be adversely affected by the subsequent termination. In addition, having many children obliges women to retreat to the private sphere to care for their offspring during the majority of their productive years. 
The fact that abortion was on the conference agenda gave the Islamists the opportunity to accuse conference organizers of encouraging sexual promiscuity. Allowing abortion was not only opposed on the grounds that killing a human life is a sin and also criminalized by law, but also that it encourages sex outside of marriage. This line of opposition was spearheaded by Sheikh Youssef El-Karadawi, a prominent Islamic figure, and adopted both by the religious establishment and the Islamic opposition.$^{187}$

Another argument that was presented against abortion was that it would inevitably lead to the depletion of human resources needed in the development process. The example of countries such as Japan ${ }^{188}$ and Romania, ${ }^{189}$ who have reconsidered their "pro-abortion" policies for similar reasons, are cited to substantiate this stance against abortion. ${ }^{190}$ While the notion of conspiracy is also present in this line of reasoning, it was somewhat, though not totally, subdued by the fact that the Vatican maintained its stance against abortion. Moreover, the Islamic religious establishment's position on abortion was somewhat divided. Al-Azhar University was adamant that "[N]o sexual relations outside of marriage would be allowed, neither would abortion except in cases where the mother's life is endangered"191 This link between illicit sexual relations and abortion was emphasized at the expense of the reality of underreported abortions and maternal mortality due to the complications from unsafe abortions. The Mufti's view, which came under attack, was much more cognizent of reality. He conceded that under certain extreme psychological and social circumstances, abortion could also be tolerated. ${ }^{192}$

The issue of female circumcision/FGM raised (and still raises) the most controversy. This practice is prevalent in Egypt among both Muslims and Christians, in the belief that partial removal of the external genitalia will stunt the sexual instinct, thus ensuring the proper conduct of girls. Other reasons cited for the procedure include cleanliness (tahara) and custom (urf). ${ }^{193}$ Although most Islamic religioius jurists admit that the practice is not rooted in Islam, there are some who insist that it is. They base their claims on the following hadith (prophetic saying): "In al-khitan sunna l'il-rigal mokarama l'il-nisa"" ("Circumcision is prescribed for men and favored for women."). ${ }^{194}$

Although it had declared the above hadith to be unreliable, Al-Azhar nevertheless avoided outright opposition to FGM. Rather, it engaged in discussions about the degree of circumcision and the conditions under which it should be performed, to ensure the physical safety of the girl. Information about the adverse psychological effects of FGM was ignored and the focus instead was on proven physical harm. Islamists claimed that the West placed this particular issue on the ICPD conference agenda in order to distort the image of developing countries, especially Islamic ones, and in order to divert attention from the exploitative politics of the West.

However, the debate about FGM in Egypt had begun long before the ICPD, but until then in a more discreet manner, and for the most part within the confines of the medical community. By

187 "Dr. Youssef El Karadawi Al Daeya Al Islami: Motamar Al Sokan Ebahi Wa Mani Al Hijab Fi Al Madaress Ded Al Sharia." July 29, 1994.

188 Japan's stance is not exactly pro-arbortion. They turn to abortion when contraception fails, which happens often because the main method adopted is condoms while the pill is prohibited.

189 While this source cites Romania as having a pro-abortion stance, during the reign of Cocesceau, Romania was known for its extremely anti-abortion policies.

190 “Haqaeq Morra" (Bitter Truths) Al Haqiqa, August 1994: xx-xx.

191 Al Akhbar, 12 August 1994: xx-xx.

192 Al-Ahram, October 1994: xx-xx.

193 For detailed discussions of the rationale for FGM, refer to Zulfikar, 1995: 87-90; El-Zanaty et al., 1996: 182; the EFCS, 1996: 16; and Wassef, N, 1998.

194 Al-Ahram, October 1994. 
bringing it into the public forum, the ICPD uncovered the diversity of positions and perspectives related to FGM. In addition, a national coalition was created (the FGM Task Force) with the ultimate objective of totally eliminating the practice. A turning point in the FGM debate was the broadcast of a documentary of a young girl's circumcision on CNN. The film was attacked, and charges were pressed against both the producer and the network. ${ }^{195}$ The gist of the attack was the negative image of Egypt portrayed by the documentary. It is noteworthy that people from all strata of society, regardless of their ideological orientation, felt more angered by the broadcast of the film than by the practice.

The CNN film led to a denunciation of the practice by the Minister of Health, and a promise to issue a law penalizing the practice of FGM. This promise resulted in the Ministerial Decree 261 of 1996, which forbade the performance of FGM in state-run medical facilities. The decree was subsequently declared unconstitutional by a district court, but a higher Constitutional court reversed this ruling in December of 1997. ${ }^{196}$

The Egyptian government's reluctance to legislate against FGM can be understood as due to the prevalence and sensitivity of the practice, and, also because it still enjoys wide support as a rite of passage signaling the end of childhood and the beginning of womanhood. The state has its own agenda, which does not necessarily include women or allow their concerns to occupy a forefront position. On the other hand, placating and containing the Islamists is a priority for the state whose very existence depends on maintaining a balance between its own ideological requirements and those of the Islamists. The fact that women have come to realize that they are usually shortchanged in the process is reflected in their current strategies of resistance. These have developed based on a variety of approaches and needs, which are explored in the following chapter.

\footnotetext{
195 The court ruled in 1997 in favor of the producer and the network and charges were dropped; the court's ruling occurred after the reversal of the Ministerial decree against FGM.

196 For further information on this issue, see the discussion of the FGM Task Force in the section entitled Strategies of Resistance.
} 


\section{STRATEGIES OF RESISTANCE}

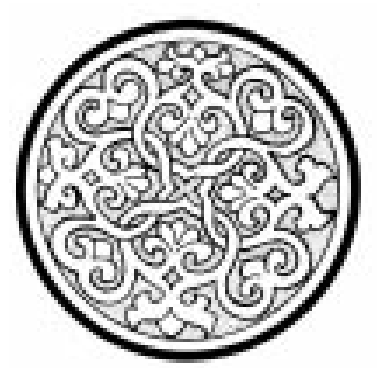

In response to women's realities and problems, during the last two decades a new generation of women's rights activists-both individually and collectively-began forming alliances with those working within a development perspective. Their aims were to create alternative discourses and scenarios for women in the hope of eliciting positive change. They have sought to achieve this through a wide variety of approaches: providing services, advocacy, research, publishing, and scholarship. NGOs have become a significant vehicle for many of these activities.

Several factors are responsible for the increase in the importance of NGOs and NGOs registered as civil companies. ${ }^{197}$ First was the failure of the government to respond to many of the basic needs of women and society as a whole. Second, the UN Decade for Women placed women's agendas on the international scene. Third, the rise of Islamic movements in the region encouraged the formation of other social movements to counterbalance them. ${ }^{198}$

In looking at the history of organizations working on women's issues in Egypt, it becomes apparent that the level of their participation, as well as the kinds of activities they undertook, have varied over time. Trends from women's welfare and social work earlier this century still present themselves in some organizations that target women and whose work does not overstep the boundaries of charity into lobbying or activism. As we shall see in this section, the more youthful organizations, those that were founded within the last two decades, with their emphasis on women, have a different framework altogether. Activism, advocacy, and research are united in an effort to obtain rights for women and to improve their status.

In the early decades of this century, organizations were welfare-oriented and mainly focused on providing services such as health care, or teaching women crafts as a source of income generation. Mubarat Mohamed Ali (discussed previously) was founded in 1908 by Huda Shaarawi and other women from the elite and the royal family. This organization was a precursor to government health care programs. While there was some advocacy especially from the 1920s to the 1950s-attempts to elicit change in laws and in women's lives-the framework of most of these organizations was structured around assisting the underprivileged. The EFU and the Bint al-Nil Union (Daughter of the Nile Union) were among the exceptions. They were the most active and took the initiative in programs geared toward women's education-encouraging the government to follow suit.

Similarly, on the health and population front, NGOs took the initiative in family planning campaigns until the government eventually made it a state policy. However, the 1960s also ushered in a wave of controlled activity whereby most NGOs became extensions of the government and implemented its policies. Others adopted the less confrontational goals of charity and welfare.

Some organizations have preferred to register as civil companies to avoid being regulated by the Ministry of Social Affairs and the restrictive Law 32.

198 For an analysis of these factors and conditions, refer to Hatem, 1993. 
As the role of the state in the development process began to grow in the early 1950s, and was expanded to include all areas of activities with the beginning of the 1960s, the developmental role of NGOs dwindled and became almost exclusively confined to charitable assistance. The exceptions were NGOs active in the field of family planning, for they played a pioneering role in this field. ${ }^{199}$

During the 1960s the government took control of all organizations: those that were seen as beyond government control were shut down; the rest were required to register with the Ministry of Social Affairs (MOSA) under Law 32 of 1964. This law is being revised, and there is general anxiety in the NGO community that it will be even more restrictive than the previous one, dealing a deadly blow to civil society. Currently in Egypt there are 14,000 NGOs registered under the MOSA-ironically, some of these were actually set up by MOSA, which is contradictory to the meaning and purpose of an NGO.

The 1980s and 1990s saw a change in the nature of women's organizations. Some organizations have become more vocal and refuse to be extensions of the government and its policies. During the ICPD, representatives from many women's organizations from different governorates in Egypt met each other and were able to network. As a result, the 1990s have witnessed new structures emerge in the women's arena, the most important of which are coalitions. There are several women's networks or coalitions currently active in Egypt working in different areas: violence against women, female genital mutilation, family planning, and reproductive health.

\section{A. WOMEN'S ORGANIZATIONS}

The organizations and projects discussed in this section are some of the best advocates for women's rights in Egypt. Following is a discussion focusing on the work of a selection of six organizations and one project currently active in Egypt in the hope that we may do them justice. ${ }^{200}$ These particular NGOs are based in Cairo although there are others that also work outside Cairo, like CEOSS, ${ }^{201}$ that are extremely active. The Cairo-based NGOs, by virtue of their location, affect a large number of women. This does not deny the valuable contributions that other organizations, independent researchers, and activists have made and continue to make in various fields. However, these Cairobased organizations were chosen because they are active in fields discussed in this monograph. The overriding rationale for their inclusion was their explicit dedication to women's issues and the fact that in many ways these organizations are pioneers in the work they do.

No Islamic organizations are discussed in this chapter because unlike the organizations portrayed here, their goals in large part are not geared toward women's empowerment. That is not to say that Islamic organizations do not provide social services. Islamic organizations on the whole have been very active in catering to the needs of their communities (Copts and Muslims), which is one of the main reasons for their popularity and deep-rooted support in society. However, the gender component and the notion of gender equity are absent from their work.

Our case studies revealed a number of trends in the experiences of the organizations discussed

199 National NGO Committee, 1994: 62.

200 Nawal El-Saadawi's Arab Women's Solidarity Association (AWSA) was not covered in this monograph because their branch in Egypt was closed down in 1991.

${ }^{201}$ CEOSS (Coptic Evangelical Organization for Social Services) is mentioned in the discussion of the self-esteem workshop later on in this chapter. 
here. First, common to all, was the scarcity of human resources: a lack of volunteers and the necessary prerequisites for training them. Second, most started with a fixed agenda but then moved into related fields due to an increased demand for their services. Third, their long-term goals have largely become focused around the desire to replicate models they have already successfully developed in other places. Fourth, most of the organizations active at the grassroots level measure their success according to how well they have integrated within their chosen communities and created close ties with the inhabitants. Fifth, these organizations were created largely due to the fact that their founders had identified a problem but were unable to find an existing forum through which they could work. The same circumstances led to the creation of the EFU in 1923. Sixth, reliance on foreign funding because of an unfortunate lack of local funding illustrates an imbalance within Egyptian society that needs to be addressed.

In Egypt there is a rich tradition of charitable works such as the endowments (waqf), which go back to Islamic traditions. During the last few decades, tables of mercy (ma'idat al-rahman) have filled the streets during the month of Ramadan offering free meals to break the fast. The tradition of giving is heavily ingrained in society, but often it is limited to charity and does not extend to donations to women's rights organizations. The fact that there is no local financial support for these organizations, either through the government or private funds, indicates either a lack of awareness and/or an unwillingness to address the issues on the part of society as a whole. Local support comes from dedicated volunteers who work in these organizations and their circles who may offer them non-financial support in the form of advice, consultation, translation, or similar services.

These organizations carry our hopes for the future. We did not call this chapter Coping Strategies, but preferred the more active Strategies of Resistance. These organizations are not only offering services geared toward alleviating the burdens women face in their daily lives; they assist women in different forms of resistance that will lead to change. We hope that their continuing efforts on behalf of women will be recognized and supported by society in the near future.

\section{Women and Memory Forum: Knowledge is Power}

In chronicling the contributions of women in Egyptian and Arab history, it became apparent that little was known about women's lives and that some emphasis was placed on certain women while others were completely overlooked. Within mainstream orthodox history, however, women have been altogether marginalized. Enter the Women and Memory Forum. A group of women formed an organization (registered as a civil company) to explore traditional

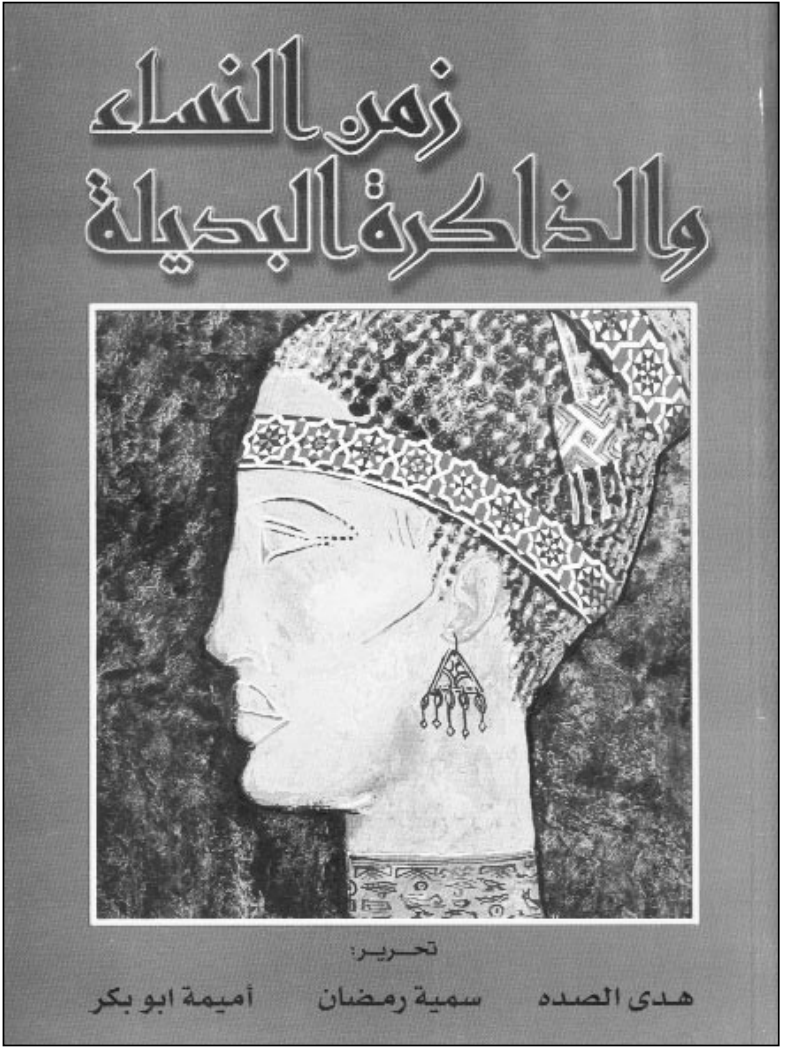

COVER OF THE BOOK:

"WOMEN'S TIME AND AUTHORED ALTERNATE MEMORY" BY MEMBERS OF THE WOMEN AND MEMORY FORUM. 
Arabic historical texts and to rediscover discourses on women through a gender-sensitive rereading of history. They are united by their common interest and by the interdisciplinary approach they promote. The sharing of experiences is enriching for scholars whose interests often dictate that they work alone. They are working toward the production of scholarly material on gender in Arabic because research in this area is mainly in English and French. In the words of Huda Elsadda, one of the founding members of the Forum: "...we wanted to make scholarly work in Arabic available to people." 202

This group originally started in 1995 sponsored by the New Civic Forum. In 1997 they became independent. "We would have been happy to work through another body or forum, but that was not possible, keeping in mind that we wanted to do scholarly research within an activist framework in Arabic." ${ }^{203}$ This points to a fundamental problem: there are no specialized national institutions that would support scholarly historical work from a gender-sensitive perspective. Women's history is not a recognized topic and not one that is normally funded.

One of the aims of the Forum is to use their research to produce educational material that can be widely disseminated. Rewriting fairy-tales and other genres of popular culture from a feminist perspective is another priority. This is intended to offer an alternative image of women and to inject gender awareness into children and young people. The Forum is also writing biographies of women who were involved in some feminist activity from the late nineteenth and early twentieth centuries, in the hope of "retelling the period through the lives of these women." ${ }^{204}$ They also held a two-day conference to commemorate Malak Hifni Nassef eighty years after her death. ${ }^{205}$ In June 1999, they hosted a similar event for Nabawiya Musa. Their long-term goals are consciousness-raising, the establishment of a library with manuscripts and documents that can be accessible to all researchers, a database of material, and the creation of alternative discourses on women.

The Forum does research within an activist framework. As Elsadda notes:

We emphasize scholarly research because we feel that this is the missing link: the history of women's activism in Egypt. One of the reasons for the regression we are witnessing now is because there is no solid accumulation of knowledge in the field of women's studies within history. ${ }^{206}$

Elsadda calls the work of the Forum "cultural development," because within a holistic picture of development, all the factors need to be examined. The Forum members firmly believe that scholarly research in history will better our understanding of what has happened and what is happening: "[W]omen were an important part of society and had an active role in the creation and articulation of Arab history... they have been suppressed in orthodox, mainstream history." ${ }^{207}$ Revisiting the government, Islamist, liberal, and nationalist-liberal discourses in a spirit of critique regarding their stances on women will be extremely beneficial in the creation of alternative discourses. Ultimately, "the meaning and function of history in its relationship with the present" has to be explored. ${ }^{208}$

202 Interview with Huda Elsadda, 15 October 1997.

203 Ibid.

204 Ibid.

${ }^{205}$ On that occasion they also reissued Malak Hifni Nassef's collection of essays entitled Al-Nisa'iyat with a new introduction by Huda Elsadda.

206 Interview with Huda Elsadda, 15 October, 1997.

207 Elsadda, 1998b: 1.

208 Ibid: 2. 
Like other NGOs, the Women and Memory Forum receives foreign funding which is vital for its continued existence. However, unlike many other organizations, it has been able to secure some local funding as well. The members believe strongly in the importance of networking; hence they produce a newsletter to enable the dissemination and sharing of information with other researchers within the Arab world and outside it. This Forum is ultimately striving to "construct an alternate story about women, the past and the present; and in doing so challenging the dominant discourses that have put women down and belittled their achievements." ${ }^{209}$

While scholarly research and activism can be seen as two mutually exclusive domains in women's development, the work of the Forum demonstrates that scholarly work, and the knowledge derived from it, is a powerful tool that, if used well, can lead to the restructuring of an entire historical memory. In challenging and changing our perception of women and their role within society, we can alter the preconceived ideas that govern women's lives today. Only through the added component of cultural development can a society fully develop.

\section{Nour: Arab Women's Publishing House}

Women, especially when impoverished and uneducated, are marginalized and discriminated against in their daily lives. This peripheral existence, however, is not confined to a certain class of women. When a group of women decided to found Nour in 1992, they were fighting women's peripheral standing within academia and as subjects of research: "we wanted to provide a space for women to publish and a forum for women's issues to be discussed." ${ }^{210}$ Like the Women and Memory Forum, Nour was created to fill a void in the existing system. The founders believed that existing publishing houses were not sufficiently sensitive to women's issues and women's writing, and thus created their own.

Nour is a publishing house, but it also organizes seminars and workshops and commissions research in various fields and publishes a newsletter. This newsletter functions as a networking device and informs researchers and scholars of books by and about Arab women. Nour also organized the first Arab Women's Book Fair in November 1995. The book fair brought together women and men from the Arab world to discuss women-related issues. Networking, as both the newsletter and the book fair illustrate, is extremely important to Nour. The Nour newsletter "promotes women, their work, and links people regionally, an important factor within the Arab world since some voices do not get heard purely due to geographic reasons." ${ }^{211}$

Nour does not confine itself to one discipline. Its publications and research projects are in the fields of health, the social sciences, creative writing, and other topics within the humanities. Future plans involve broadening their base, becoming self-sufficient, and getting involved in further projects. The feedback Nour has received from its projects supports the need for their work. But as always, human resources are a problem. Nour survives on the strength of its work; more people's time and effort are needed to achieve their goals, especially sustainability.

\footnotetext{
209 Interview with Huda Elsadda, 15 October, 1997.

210 Interview with Soraya Altorki, one of the founding members of Nour and a member of the board, 26 October 1997. The Nour board is made up of seven other women from various disciplines.

211 Ibid.
} 
Nour prides itself on having given women that "room of one's own"212 essential for the fulfillment of self-expression. As Altorki notes:

We have provided women with a space where they can express their views and get maximum exposure in an atmosphere of equality. We give them an opportunity not just because they are women, but because they are good and merit it. As we know, even the most qualified and gifted of women don't always get a fair deal. ${ }^{213}$

\section{Association for the Development and Enhancement of Women (ADEW): "Give Me Credit for Being a Woman!"214}

Family structures have changed over the last three decades in Egypt, a fact that society is slowly recognizing. Recent surveys show that at least one out of every five households is supported and headed by a woman. Government policies, however, are based on an image of the family that assumes that only men are breadwinners. In response to this growing trend and to women's lack of access to credit and income-earning opportunities, a group of seventeen women and three men working in different development fields founded the Association for the Development and Enhancement of Women (ADEW) in 1989.

ADEW grew out of a credit program for women-headed households at the Mokattam Garbage Collectors' (zabaleen) Settlement from 1985 to 1987.215 This experience made some of the members conscious of both women-headed households and the constraints faced by poor women in accessing credit. For example, the loans offered are typically too large for women who want to engage in small business activities alongside their responsibilities for their homes and children. Furthermore, inappropriate collateral requirements, such as the possession of an identity card and the signature of a male guarantor (which is required by most credit programs in Egypt) present obstacles for women. In the words of Heba El-Kholy, one of the founding members of ADEW:

...clearly there were a lot of families for whom women were responsible and we found it very difficult to convince anyone else of this. We tried to replicate this project in other communities but we could not find an institution or structure where we could do that. Basically, then we thought let's set up our own-that is how it started. It started for a very specific reason: to try and replicate a credit model and through that set up a gender sensitive credit institution which can address women's unequal access to critical resources as well as propagate the issue of women headed households. ${ }^{216}$

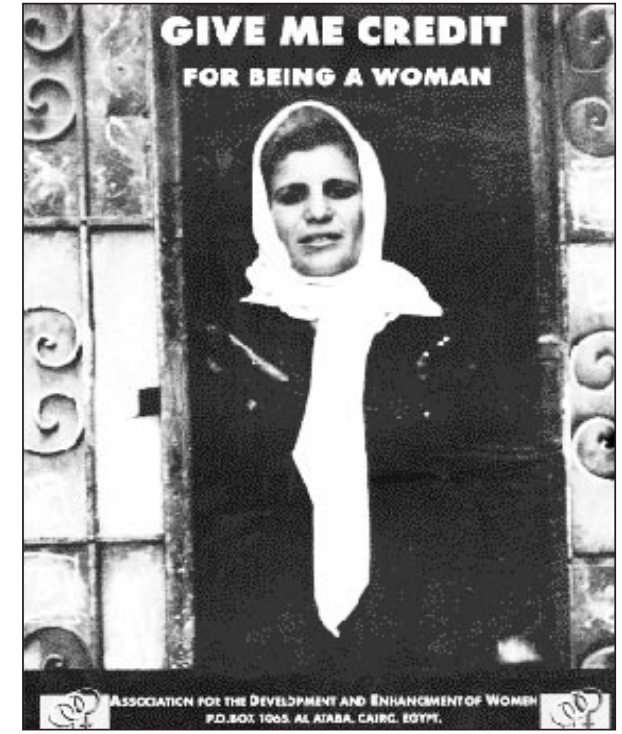

ONE OF ADEW'S POSTERS PROMOTING CREDIT

\footnotetext{
${ }^{212}$ This refers to Virginia Woolf's feminist essay, A Room of One's Own (1987), which discusses the components necessary for women to express themselves.

${ }^{213}$ Interview with Soraya Altorki.

214 This is a slogan of the Association for the Development and Enhancement of Women (ADEW), found on one of their posters. In Arabic ADEW is: Gamiyyat Nohoud wa Tanmiyat al-Mar'ah.

215 This program was implemented under the auspices of Environmental Quality International (EQI).

216 Interview with Heba El-Kholy, 13 October 1997.
} 
The founders of ADEW believed that there was a category of families and women that were perhaps consciously disregarded because their existence was threatening to the traditional notion of the family. They set out to address this category.

ADEW started its work in Manshiet Nasser, an informal settlement at the foot of the Mokattam hills in Cairo, generally regarded as a low-income area. ADEW's work has now expanded to two other low-income areas in the city. The women ADEW targets are poor, illiterate, and responsible for supporting a family. In the words of Heba El-Kholy:

We wanted to address women's rights by addressing the needs and rights of a specific category of women at a concrete level and then move from there to raise their concerns on a national level. Which is exactly what we did: others are now replicating our credit model and the constraints facing women-headed households have gained the attention of both researchers and the media. ${ }^{217}$

ADEW's backbone is credit and technical assistance, although it has branched out to cater to other unaddressed needs. They have supplied 1,200 women with credit-small loans that are payable with an administrative fee-so that they can initiate or expand income-generating activities. Women have mainly chosen to enter into food processing, vending, sockmaking and the manufacture of elastic bands. The drawback lies in the limited growth associated with these occupations. The loans have, however, played a crucial role in increasing women's incomes as well as providing employment opportunities for them. Other benefits for women are that: "the credit is partly a tool for us to mobilize women and discuss issues of concern to them, so it is more than economic support."218

ADEW's agenda and services expanded into legal literacy and health awareness to cope with the realities faced by the women receiving their support. The accessibility of government services, such as pensions, emerged as a recurring problem for women-headed households: "there is discrimination against them as women who are illiterate and poor." ${ }^{219}$ Receiving a pension from the government involves a long, bureaucratic, and often overwhelming process for poor women who do not have the necessary papers or the legal awareness to go about acquiring them, and who are also intimidated by male government officials. ADEW responded by assisting women in acquiring their identity cards, a first step in announcing a woman's existence to the government, and raising this issue on a national level.

The politics of issuing identity cards are telling of the official stance regarding women: men by law must have an identity card while women are not required to have one. Having identity cards enables women to assert their right to equal citizenship, and by extension equal rights, with men, rather than tolerating the status of secondary citizenship. Only with an identity card does one become eligible for a voting card. The difficulties of procuring identity cards called attention to the broader problem of women's legal literacy. In response, ADEW began holding informal sessions on legal awareness for women during which other organizations and independent lawyers brief women on their legal rights. To encourage them to attend these sessions, ADEW linked the subjects with concrete issues directly affecting women in their daily struggle for survival: the identity card or registering a business with the government-another ordeal. "Imagine that we are approaching the 21st century and one woman's dream is to get an identity card!"220 
ADEW has developed a credit model, based on the Zabaleen program, that they now feel can be replicated in low-income urban and rural communities. Their focus remains on urban (particularly 'informal') settlements. While ADEW is largely dependent on foreign funding, it is working toward self-sufficiency so that the credit program will continue with some degree of autonomy. So far 70 percent of the credit program's core costs are self-financed through the administration fee. Another long-term goal involves legislation affecting women-headed households: "If 30 percent of the population is financially supported by women, then very basic inequalities between women and men in the law can be very easily challenged." 221 These include social welfare policies, employment policies, and inheritance laws, all of which are based on a notion of the family that assumes men to be the sole breadwinners. "What we want to say is wait, "women are breadwinners too." 222

One measure of success, other than the loan repayment rate and increases in income and employment is ADEW's integration into the communities in which it works. ADEW communicates and coexists with various factions within the community that do not necessarily share their philosophy of female empowerment. There have been tensions between ADEW and some local conservative elements that public ally questioned ADEW's work on the grounds that they are providing 'unislamic services.' One positive result has been that these factions have begun their own services, giving loans to men and women. Another facet of success for ADEW has been in raising awareness: ten years ago the issue of women-headed households was dormant, while now it is part of the acknowledged discourse. With time, continued funds, and human resources, ADEW will continue to help women start their own small businesses and earn money, which gives them a measure of power and autonomy. Ultimately, making women economically independent expands their life options and enables them to challenge inequalities and gender hierarchies faced at home and within the community at large.

\section{New Woman Research Centre (Markaz Dirassat Al-Mar'ah al-Gadeeda)}

Five politically active women began a weekly study group in 1984 to discuss the history of Egyptian and Arab women's movement as well as some international literature, to formulate a response to questions of whether or not there should be a specific women's agenda. It met weekly for almost two years. One of the members, Hala Shukrallah, notes:

From reading literature and the historical contexts of social movements, what was reaffirmed in our minds was that women fully participated in bringing about social change. However, when these movements realized their objectives, women were at once relegated back to the home. The conclusion was that there had to be a women's movement, realized in women's organizations and institutions, which can both impose and emphasize women's agendas on society and on other social movements. ${ }^{223}$

During the mid-1980s, there were few forums open to women interested in women's issues. The group believes that its efforts were different because "we looked at a specific sector (women); we

\footnotetext{
221 Ibid.

222 Ibid. "Women are breadwinners too" is one of ADEW's slogans.

${ }^{223}$ Interview with Hala Shukrallah, 27 April, 1998.
} 
did not subordinate our cause to other broader social movements." 224 They issued a newsletter to disseminate the ideas they had formulated to a wider audience. The need for dissemination and feedback, combined with probing questions about what they were doing, moved this group into public action. In 1986 a name was chosen for the newsletter that has since remained: The New Woman.

The initial study group continued meeting in members' homes (as did the earliest women's organizations). By 1991 they were attracting attention because they were still an unofficial body and under the Egyptian Emergency laws, five people meeting regularly in a house was unwelcome. Egypt has been under Emergency laws for the last few decades, which means that some of the normal laws have been suspended in favor of stronger government control. For example, the government has the right to disperse a meeting between five or more people. The group finally registered as a civil company called the New Woman Research Centre (NWRC) on 7 February 1991. The initial members changed, they opened up to new members; they are now eleven women. All NWRC members work on a voluntary basis; only the administrative assistant gets paid. Its workshops, newsletter, and the office premises, however, are funded by foreign donors.

After all of these changes in membership, form, and positions, how does the NWRC perceive itself today? In the words of Hind Wassef, one of the group's members:

We are a group of women from different professional backgrounds, generations, and

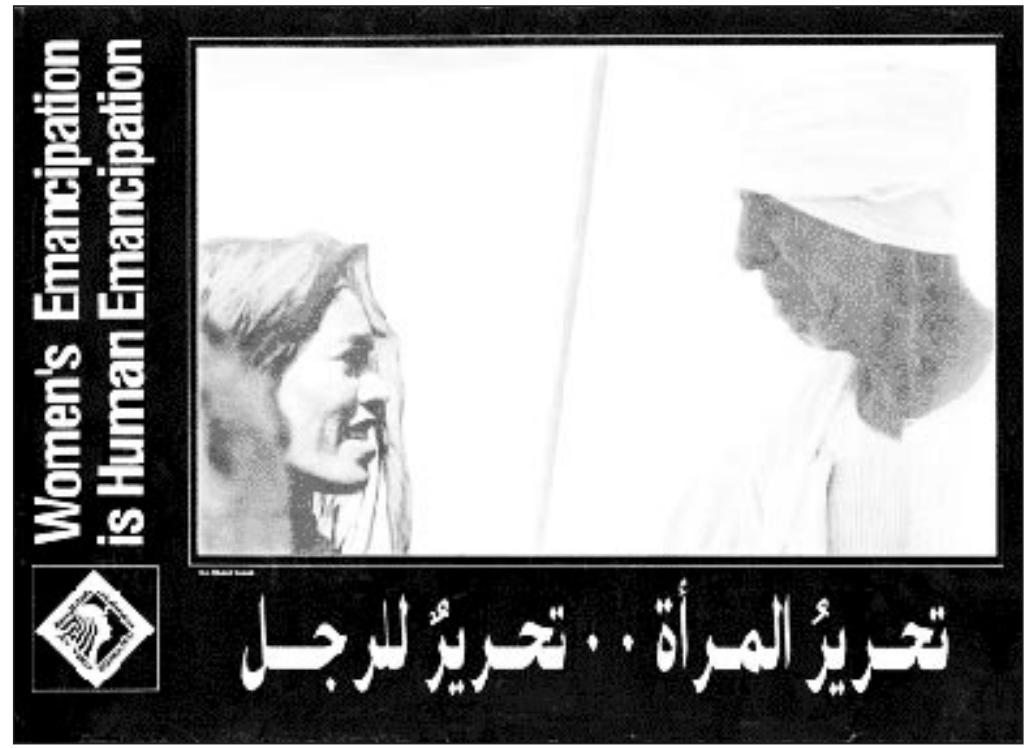

Poster by THE NeW WOMAN RESEARCH CENTRE political orientations who have

a feminist outlook and converging views on how to deal with women's issues. Even in areas where there are variations in our views, the motivation is always toward dialogue, consensusreaching, and meeting each other half-way. ${ }^{225}$

Hala Shukrallah adds:

We are organized around similar principles with the objective of creating social change, specifically targeting structural change in all that pertains to women's rights, be it social, economic, political, or cultural, using different tools and methods..$^{226}$

\footnotetext{
224 Ibid.

225 Interview with Hind Wassef, 12 May 1998.

226 Interview with Hala Shukrallah, 27 April 1998.
} 
While women may not come and ask for credit or legal assistance, male and female researchers do come to the NWRC for research, information, and networking.

The NWRC's goal is:

...to spread feminist views to as many target groups as possible. We want to be part of a democratic social movement that aims to improve women's status within society and work toward equality between the genders. ${ }^{227}$

A number of constraints on them remain, as they do on other organizations. For example, government laws do not allow demonstrations, sit-ins, or free access to the media. The NWRC works at the grassroots and intermediary levels with other organizations, and is not specialized within one field.

In an ideal world the NWRC would like a larger membership, one that would feel some degree of ownership of their projects. The NWRC would also like access to the radio and television; a year's schedule full of workshops; a hotline to deal with people's needs; access to schools; the opportunity to network and form alliances with organizations around various issues; and freedom of movement and expression. The NWRC strongly believes in working with others because working alone is futile.

\section{Centre for Egyptian Women's Legal Assistance (Markaz Qadaya al-Mar'ah al-Masriya)}

In November 1995, four lawyers (3 women and 1 man) founded the Centre for Egyptian Women's Legal Assistance (Markaz Quadaya al-Mar'ah al-Masriya). They had become disillusioned with other organizations, had not found a forum through which to address women's needs, and wanted to work at the grassroots level. They founded the organization in Boulaq al-Dakrour, one of Cairo's low-income urban districts. Why? "Because we wanted to elicit change in Boulaq." ${ }^{228}$ For the first six months they financed themselves out of their own pockets, but are now supported by foreign funding. They chose to register themselves as a civil company and hence avoid rigorous government control should they have registered as an NGO under Law 32. As with other NGOs and women's organizations, they originally began with few objectives in mind but diversified to meet growing demand for their services. The services currently provided by the Centre free of charge are:

- Literacy classes (mahw omiya): to teach basic reading and writing skills to women and men;

- Legal awareness: teaching women their legal rights;

- Legal services: these include the issuing of identity cards, voting cards, and registering people in the civil registry office (sigil madani);

- Adoption of legal cases, mainly related to the Personal Status Law;

- A telephone hotline to which people can call to ask questions and receive legal advice;

- Research: Researchers trained by the Centre have gone to people's homes to understand the needs and problems facing the inhabitants of the community.

Interview with Hind Wassef, 12 May 1998.

${ }_{228}$ Interview with Azza Soliman, one of the founding members of the Centre, 14 October 1997. 
The number of clients that seek the Centre's services has increased steadily over time. In 1996 they provided 280 people with legal services (getting identity cards or voting cards, and so forth) and helped 84 people with their legal cases. The Centre mapped out Boulaq and divided it into five areas to tackle each section systematically. Through their door-to-door surveys, the Centre realized that once the initial barriers were broken, people were eager to express their problems and needs. From 1,200 interviews with inhabitants of the Boulaq area, they have revealed massive problems facing women and their families.

The Centre's short-term goals are to help women face the obstacles they encounter and to solve some of their problems. The long-term goal of the Centre is to help women and replicate their model in other areas all over Egypt. Azza Soliman believes in helping women to "redefine their concepts and beliefs so that they will, for example, rethink who to marry and whether they will circumcise their children or not." 229 The Centre has had an extremely positive impact on the lives of community members. Some women have obtained their identity cards, voting cards, birth certificates, and are continuing their education as adults. This year twenty women and one man, after having taken literacy classes, are sitting for their first preparatory school certificates. "The people we have helped through our literacy classes tell us they finally feel they have dignity." ${ }^{230}$

They have recently established another office in the city center of Cairo; thus seventeen people in total are now working in both offices. However, they still need people willing to work within their communities on surveys and counseling; they also need funds to train their researchers and purchase office needs. While Amnesty International donated the office furniture when it closed down its Cairo office, the scarcity of these basic elements is a problem that continues to plague the Centre.

The Centre measures its success based on its successful integration into the community. The inclusion of men as their clients has helped in propagating an acceptable image to the community. The Centre has created a niche for itself in that it combines legal aid with development and human rights. Giving women the necessary papers that they have been unable to obtain previously has reinforced their sense of identity and security; they also become eligible for government assistance. Making women aware of their legal rights has helped them plan their futures and overcome obstacles in their lives. Trying women's cases free of charge gives them sympathetic counsel in an otherwise chauvinistic and costly legal system that has little time for illiterate and poor women.

\section{The Egyptian Female Genital Mutilation Task Force}

Female genital mutilation (FGM) or female circumcision is an act of violence perpetrated upon girls by society because they "are expected to constantly provide evidence of their good behavior and conduct... thus girls are given an early lesson, that control over women is a prerequisite for the welfare of society." ${ }^{231}$ It also has immeasurable repercussions on women's psychological, mental, and reproductive health. As noted above, the Egyptian Demographic and Health Survey found that 97 percent of ever-married women are circumcised-rendering it a widespread form of violence against Egyptian women. Some women from this nationally representative sample underwent a gynecological examination, and a validation study was done on the entire sample to confirm the figures. FGM is defined as:

\footnotetext{
229 Ibid.

230 Ibid.

231 FGM Task Force, 1997: 1.
} 

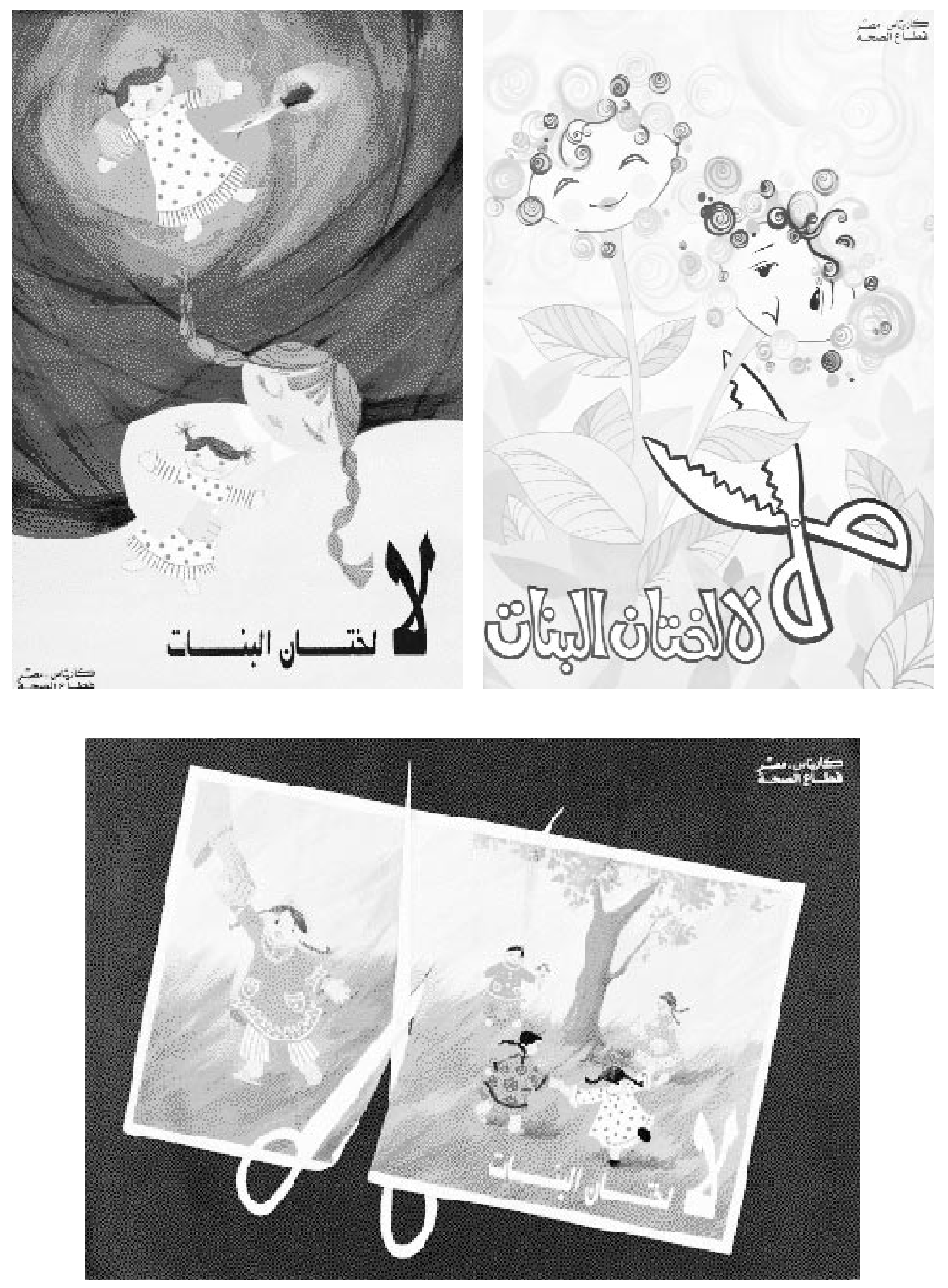

Posters Against FGM 
a total or subtotal amputation of one of the organs of the female body, a practice not recognized in any medical literature... it is performed on young girls, whose consent has not been taken or who are not in a position to give such consent. ${ }^{232}$

In some instances it is performed without anesthesia using a knife or razor. One of the problems faced by those trying to eradicate FGM is that due to its prevalence, society has become impervious to its extremely violent nature that mere words cannot relay.

The FGM Task Force, under the umbrella of the National NGO Commission for Population and Development (NCPD) was officially founded in October 1994 with Marie Assaad as its coordinator. "We like to look at the Task Force as a forum of individuals and NGOs who are concerned with the issue." ${ }^{233}$ The impetus to start the FGM Task Force came from lessons from the past: "There were individual efforts previously dealing with this practice but we knew that these efforts could only go so far. Nahid Toubia ${ }^{234}$ encouraged us and we felt that unless we created a movement and got moving on basic issues nothing would change." ${ }^{235}$ After the 1994 International Conference on Population and Development (ICPD), with its focus on reproductive health issues and the subsequent media emphasis, the campaign against FGM gained momentum and the Task Force moved with this momentum. Many more organizations joined, looking at the issue from a human and women's rights perspective. Membership has been on the increase since the Task Force's formation. Ultimately, members of the Task Force are of the opinion that FGM "is a form of violence against women, one of the indicators of gender relations in our society and evidence that discrimination is an essential characteristic of this relation." ${ }^{236}$

The FGM Task Force began with three main activities: an advocacy group (working with the decisionmakers and the media); a grassroots mobilization group; and a research group. The grassroots mobilization group has grown in size and strength under the guidance of Dr. Magdy Helmy. As a coalition of organizations working in different fields, their strength comes from this variety, which brings with it a richness of experience. In a state of constant self-renewal, the Task Force's emphasis is on two of its new projects: a resource center that houses all documents, research, and media reports on FGM and is open to all researchers; and the forging of links through networking and strengthening communication with others. Perhaps one of its biggest contributions has been the development of a new, integrated social approach in dealing with FGM eradication. ${ }^{237}$ One of the problems with previous FGM eradication efforts had been that the debates always centered around medical and religious views. ${ }^{238}$ The new approach developed by the FGM Task Force draw upon other aspects of the problem, framing it as a gender and a rights issue.

The passing of legislation regarding FGM is an act with uncertain consequences. The situation as of the latest ruling (December 1997) is that FGM is banned in all government hospitals and clinics. The exception is in cases in which it is "needed." Since FGM is never needed, this clause functions as a loophole and gives the practice some kind of medical legitimacy. Laws that prevent the

\footnotetext{
Ibid: 1.

233 Interview with Marie Assaad, coordinator of the FGM Task Force, 23 October, 1997.

${ }^{234}$ Nahid Toubia is a physician, founder of RAINBO (Research, Action, Information Network for the Bodily Integrity of Women) and an outspoken advocate against FGM.

235 Ibid.

236 FGM Task Force, 1997: 3.

${ }^{237}$ Dr. Seham Abdel Salam, head of the Resource Centre on FGM and Violence Against Women, has been instrumental in developing this new approach.

${ }^{238}$ For further information, refer to Wassef, N., 1998.
} 
infliction of bodily harm (which in theory includes FGM) in general do already exist. However legislation that proposes to ban FGM specifically, "if not supported by a popular movement, would at best be ineffective and at worst, trigger a backlash that would serve to perpetuate FGM rather than bring an end to it." ${ }^{239}$ Ultimately, the decision to stop the practice of FGM must come from the people, and only then can legislation support the decision.

Limitations affecting the strength of the Task Force and its message lie in the attitudes of people who understand the gravity of FGM but who accept its medicalization (that is, allowing the practice to occur under the supervision of doctors) rather than taking a firm stance against the practice. To accept medicalization implies an acceptance of the operation but an objection to the circumstances under which it is often performed. These conflicting messages produce "a lack of clarity which results in you being unable to communicate solid information to people on a grassroots level." ${ }^{240}$ Another drawback faced in the Task Force's work is the lack of easy and accessible literature on the subject of FGM for use in grassroots discussions and with newly literate adults.

A model for action is needed that can be replicated in communities all over Egypt. As always, human resources and their training comprise a fundamental gap that needs to be filled. However, because of the FGM Task Force, a forum finally exists that unites the interested factions while simultaneously supporting and mobilizing them. This unity, support, and mobilization are critical if FGM is to be eliminated. For FGM to become extinct, a change in the social atmosphere needs to occur:

The struggle against FGM is a struggle for the liberation of women and men from the value system that governs them both. Working toward change of this value system is in fact working toward changing society as a whole. ${ }^{241}$

Undoubtedly the Task Force will be a catalyst in this change process

\section{B. OTHER APPROACHES}

\section{Self-Esteem Project: "I am proud to be a woman!"}

While this section has discussed the work of organizations, the following innovative approach also merits documentation. This is an example of how an organization that offers social services can streamline gender sensitization and consciousness-raising into its programs. Two weeks before the United Nations Fourth World Conference on Women, the international NGO CARITAS organized a workshop in Beijing entitled Young Women Leaders. Taking action, participating in society, and mobilizing others were among the issues discussed. The United Nations, its machinery, and divisions were also discussed. Sherine Abul Naga, a member of the New Woman Research Centre, participated. She emerged from this workshop with a decision to mobilize:

I wanted to replicate this idea in Egypt with a few changes to suit the target audience. I approached CEOSS (Coptic Evangelical Organization for the Social Services) and they invited thirty Christian and Muslim women from organizations and NGOs between the ages of 20 and

239 FGM Task Force, 1997: 1.

240 Interview with Marie Assaad, 23 October, 1997.

${ }^{241}$ FGM Task Force, 1997: 6. 
25 who were either married or single from nine marakiz ${ }^{242}$ in the Minya governorate in Upper Egypt to attend this workshop. ${ }^{243}$

CEOSS proved to be the ideal agent in organizing this workshop for a variety of reasons. CEOSS is a grassroots development organization that was established in 1950. While its name implies a religious emphasis, in its current work it has addressed the needs of both Christians and Muslims. CEOSS has worked extensively in community development in almost two dozen communities within the Minya Governorate. While they target the entire family-men, women, and childrenwomen are especially important to them.

After CEOSS managed the logistics, it was decided that the workshop would be held over a period of three days with each day divided into two sessions. Abul Naga began the workshop with a test based on popular psychology, to assess the participants' self-image. Then they talked about differences between men and women until they arrived at an important question: why do men beat women?

They all thought that beating a woman was a normal thing because it taught her to behave properly and not to make mistakes. They all had one reservation: women should not always get beaten. A woman had to really deserve it, she had to have done something terribly offensive to her brother, father, and husband-(interestingly enough, offenses only to men). By the end of the workshop, they unanimously agreed that it was not acceptable regardless of the extent of a woman's wrongdoing. After all, when a man does something wrong who punishes him? $?^{244}$

The women discussed their problems: "They know that they should not be treated in this way but the options seem limited. Sometimes they have to do things that they don't want to." ${ }^{245}$ When talking about self-esteem, the women expressed feelings of guilt because "they have duties they are not fulfilling and consequently they feel they are not living up to the standards set for them by society." ${ }^{246}$

The participants also discussed the media at length. The images of women in the media were offensive to the workshop participants: “They don't feel in anyway represented in the media." ${ }^{247}$ Abul Naga asked them to evaluate the women's page in the Friday supplement of Al-Ahram (the main government-run newspaper). The week's recipe was fish in an orange sauce. The women found it comical and far removed from their realities; for example, the hairstyles were taken out of a foreign magazine and could only be raplicated with the help of an experienced hairdresser. As a response to these articles, the women worked in groups to create their own magazines. Theirs contained literature, tips that help them in their daily lives, such as how to recognize food that has gone bad and articles on women's consciousness. "I was impressed, I remember thinking at the time, that if these women ever did a magazine, it would be really wonderful." ${ }^{248}$

The women were also told about the history of the Egyptian feminist movement by Nadia

\footnotetext{
${ }^{242}$ A markaz (singular) is a district in a governorate. Every governorate is split into several marakiz, which are further split into sheikhdoms.

${ }^{243}$ Interview with Sherine Abul Naga, the activist responsible for this initiative, 19 September, 1998.

244 Ibid.

245 Ibid.

246 Ibid.

247 Ibid.

248 Ibid.
} 
Abdelwahab and "were glad to know that there were women who had struggled in the past."249 The fact that they had never heard of Huda Shaarawi illustrates the gaps in the school curriculum and the selective nature of mainstream history, a gap that the Women and Memory Forum is addressing. CEOSS asked Abdelwahab to repeat this lecture to other groups; in most cases, the group members had no previous knowledge of a women's movement in Egypt.

The women in this workshop were very responsive to the agenda. They bonded and identified with one another and their problems. Another achievement of this initiative was that these women spent three consecutive nights away from their homes: "This broke a lot of stereotypes that I had in my mind: women can leave their homes. I also discovered that Muslim and Christian women had identical problems." ${ }^{250}$ Before leaving, each woman was given a sheet of paper to draw up plans for each quarter of the upcoming year. They all met three months later to share their achievements. CEOSS followed up and organized more meetings and workshops in which some of the women still persevere in their path to empowerment.

Ideally, this workshop should be replicated in different settings all over Egypt. As always, however, the lack of funds and human resources is crippling. The housing, food, and transportation expenses for 30 women were costly for CEOSS, and arranging the logistics was time-consuming. As Abul Naga's results show, however, it was an extremely worthwhile and beneficial experience for all involved. This endeavour is also important in that it can be easily streamlined into the activities of other organizations, which may not necessarily be women's rights organizations but have a program addressing women, or providing services for them.

\section{PLANNING AHEAD}

As noted at the start of this section, the organizations discussed shared a number of concerns and common trends. Networking, capacity building, accessing the media, forging greater alliances, and streamlining women's issues into other programs and projects could also be added to the list. However, there are a few points that we would like to emphasize that became apparent from the case studies as a whole.

\section{Capacity-building}

Capacity-building as a need will always exist, but it varies depending on an organization's goals and the ever-changing reality in which it operates. A vital component of capacity building thus becomes the need for self-evaluation and renewal. Hala Shukrallah, the director of the Development Support Centre, advocates coping with these evolving realities through a process of assessment, "change is a planned and scientific process, you need to evaluate yourself and your surrounding environment to continue to have the best impact." ${ }^{251}$ Many of the aforementioned organizations and individuals have been active throughout the 1990s. During this period social, political, and economic changes have occurred in Egypt, which have affected them and their target groups in different ways. Organizations need to step back, assess these changes, and make the necessary realignments to better address these new realities.

\footnotetext{
249 Interview with Nadia Abdelwahab Al-Afifi, speaker on the history of the women's movement in Egypt, 22 October 1997.

250 Interview with Sherine Abul Naga.

251 Interview with Hala Shukrallah, director of the Development Support Centre (DSC), 9 November 1998. The DSC is a consultative office that offers assistance to organizations by accompanying them in the process of developing their strategies, capacities, and needs.
} 


\section{Reaching Out}

An organization's sphere of influence affects its impact. Most organizations do research and advocacy but do not disseminate their findings outside of a specified circle. Sharing information, ideas, and findings with one's target groups and disseminating to government bodies transforms information into a powerful tool. Generating allies within the government is vital; however, the formation of allies necessitates strength and pressure to counteract the fact that one's agenda may not be a priority of the government and that common ground may be limited-if there is indeed any at all.

Negotiation skills are vital. Organizations need to recognize the different types of advocacy that they can employ in negotiating to achieve their goals: talking, disseminating information and data, and applying pressure, for example, have varied impact. Forging ties within the community and organizing monitoring structures that place demands on the government are sources of leverage. An organization's strength is often derived from its constituency, in that it is in touch with people's needs and can faithfully represent their interests. In this light, the organization's role becomes that of an intermediary between the people and the government, helping to make its constituents' demands heard.

\section{Men's Roles}

The absence of men from the women's movement needs to be remedied. While this was not an explicit recommendation voiced by the groups interviewed, we believe it is an implicit one. Men need to be allies in this struggle and to offer their support on many levels. Involving them could help in widening the discourse on women's issues, such as FGM and violence against women. Currently the discourse on these issues places them within the realm of women's problems. They are not. They are problems for the society as a whole and combating them can only take place successfully with men as active participants in the struggle. Women and men need to work together to elicit social change for their mutual benefit.

Another dimension of this issue is that men need to be studied (understand their perceptions and attitudes on certain issues) and addressed (create strategies to target and involve them). If most of these organizations are interested in gender, then they have failed to address half of their audience. What is the point of educating a woman about her rights when her father, brother and husband remain ignorant of all these issues? Men should be involved in awareness-raising sessions that inform women of their rights in, for example, health care, before the law, and as citizens. 


\section{CONCLUSION}

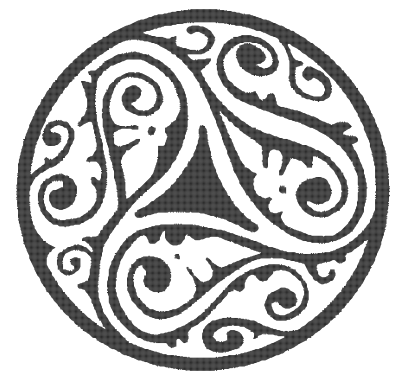

Throughout this monograph, we have seen the variety of discourses and causes through which the issue of women's rights has been relayed and often subsumed. The fact that women are perceived as the bearers and perpetuators of cultural values and social mores increases the resistance to any change in their status and the laws that govern their lives. In times of rapid change, ideological failures, economic restructuring, and a sense of lost identity, the burden falls on women to guarantee the nation's cultural authenticity. They are often caught between the state and religious conservatism. The result is visible in the public discourse on women, which treats them as secondary citizens, and in the impasse reached on some women's issues. An example of this is the nationality law. A great deal of lobbying has been done around this issue; yet it seems that resistance from government factions is much stronger. Ultimately, being caught between the currents of religious conservatism and state ambiguity means one of two things: either women's concerns are deprioritized and sacrificed in favour of other 'more important' issues; or compromises are made at their expense. These factors will undermine the rights women gained during this century and stand in the way of achieving their remaining goals.

Women will continue to be divided over the definition of their gender interests, over the nature of social arrangements which best serve them and over their visions of a better society. It is important to remember that their various movements are responses to similar sets of contradictions and that their discourses are circumscribed by the political cultures of their societies. Ultimately feminist movements in Muslim societies, as elsewhere, will take their place alongside the social forces struggling for civil and democratic rights in their respective countries. ${ }^{252}$

Today, unrealistic hopes for progress are tempered by the bitter trail of broken promises. Women's demands must stand on their own, not under a larger umbrella. Women's organizations are faced with the challenge of amplifying women's voices, to articulate and relay their own deficient realities and attempt to create better ones. A movement that demands rights for the purpose of realizing equality and liberation for women and men will eventually triumph. We will be heard.

Kandiyoti, 1991: 18. 


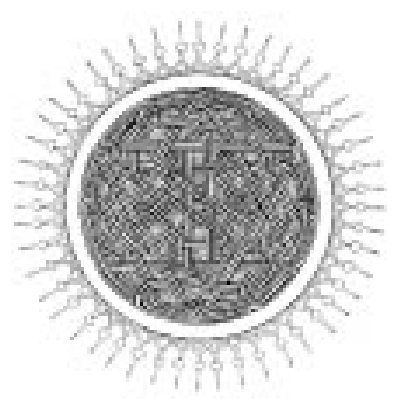

\section{COMMENT}

"Akher Iftera'at Wazir al Talim ..Al Hijab Horeya Shakhseya" (The Minister of Education's most recent allegation...Donning the hijab is a matter of personal choice), 1992

“Al-Jeans Fi Wezarat Al-Awqaf!" (Jeans in the Ministry of Religious Endowments!), 1991

"Dr. Youssef[SML16] El Karadawi: Al Daeya Al-Islami: Motamar Al-Sokan Ebahi Wa Mani Al-Hijab Fi Al-Madaress Ded Al Sharia." Population Conference is obscene and forbidding Veil in schools is against the Shari'a) 1994 ((July 29). Al-Ahrar, p. 10.

“Haqaeq Morra" (Bitter Truths). 1994 (August XX). Al-Haqiqa. p. XX.

Abdel Atty, M. 1995. "El-Harakat Al-Islamiya Fi Masr" (Islamic Movements in Egypt). Al-Ahram. p. 122-123.

Abdel Nasser, Walid. 1994. The Islamic Movement in Egypt: Perceptions of International Relations 19671981. London, UK: Kegan Paul International.

Abdelkader, Soha. 1982. The Image of Women in Drama and Women's Programs in Egyptian Television. PhD Dissertation. Cairo, Egypt: Cairo University Faculty of Mass Communication.

Abdelwahab, Nadia. Interview conducted by Nadia Wassef, 22 October, 1997.

Abed, Nefissa. 1998. October Magazine. p. 100.

Abou al-Isa'ad, Mohamed. 1994. Nabawiya Musa Wa Dorha fi al-Hayah al-Masriya (Nabawiya Musa and Her Role in Egyptian Life). Cairo, Egypt: General Egyptian Book Organisation.

Abul Naga, Sherine. Interview conducted by Nadia Wassef, 19 September, 1998.

Ahmed, Leila. 1993. Women and Gender in Islam: Historical Roots of a Modern Debate. Cairo, Egypt: American University in Cairo Press. 
Al Ahram. 1997. “Tortured Employees of the Registry.” November 5, 1997.

Al Ahram, October 1994.

Al Ahram, October 1994.

Al-Ahram Weekly. 1996 (28 March-3 April) “Alifa Rifaat by Alifa Rifaat.” p. 11.

Al Akhbar, August 12, 1994.

Al-Ali, Nadje. 1998. Standing on Shifting Ground: Women's Activism in Contemporary Egypt. PhD Dissertation. University of London: School of Oriental and African Studies, 1998.

Al-Ghazali, Zeinab. n.d. Ayyam min Hayati (Days of My Life). Cairo, Egypt: Dar al-Shorouk.

Al-Taymouriya, Aisha. 1887. Nata'ij al-Ahwal fi al-Aqwal wa-al-Af'al (The Results of Circumstances in Words and Deeds). Cairo, Egypt:

Altorki, Soraya. Interview conducted by Nadia Wassef, October 26, 1997.

Arafa, Bahiga. 1954. The Social Activities of the Egyptian Feminist Union. Cairo, Egypt: Elias Modern Press.

Assaad, Marie. Interview conducted by Nadia Wassef, 23 October, 1997.

Assal, Ihsan. 1990. "Bayt al-ta'ah." (House of Obedience). In Margot Badran and Miriam Cooke (Eds.), Opening the Gates: A Century of Arab Feminist Writing. London, UK: Virago: 160-167.

Awad, Mahmud. 1977. “The Umm Kulthum Nobody Knows as told by Umm Kulthum to Mahmud Awad." In Elizabeth Warnock Fernea and Basima Qattan Bezirgan (Eds.), Middle Eastern Muslim Women Speak (pp. 134-165). Austin, TX [USA]: University of Texas Press.

Badran, Margot, and Miriam Cooke (Eds.). 1990. Opening the Gates: A Century of Arab Feminist Writing. London, UK: Virago.

Badran, Margot. 1991. "Competing Agenda: Feminists, Islam and the State in Nineteenth and Twentieth Century Egypt." In Deniz Kandiyoti (Ed.), Women, Islam, and the State (pp. 201-236). London, UK: Macmillan.

Badran, Margot. 1992. "Expressing Feminism and Nationalism in Autobiography: The Memoirs of an Egyptian Educator." In Sidonie Smith and Julia Watson (Eds.), De/Colonizing the Subject: The Politics of Gender in Women's Autobiography (pp. 270-293). Minneapolis, MN [USA]: University of Minnesota Press. 
Badran, Margot. 1996. Feminists, Islam, and Nation: Gender and the Making of Modern Egypt. Cairo, Egypt: American University in Cairo Press.

Baron, Beth. 1989. "Unveiling in Early Twentieth Century Egypt: Practical and Symbolic Consideration." Middle Eastern Studies. Vol. 24(3): 370-386.

Baron, Beth. 1994. The Women's Awakening in Egypt: Culture, Society, and the Press. New Haven, CT [USA]: Yale University Press.

Blanks, David R. 1999. "Gendering History: Europe and the Middle East." Alif: Journal of Comparative Poetics, 19: Gender and Knowledge; Contribution of Gender Perspectives to Intellectual Formations (pp. 43-67).

Chemais, Amina. 1987. Obstacles Hindering Muslim Women from Obtaining a Divorce. Cairo, Egypt: UNICEF.

Cooke, Miriam. 1994. “Al-Ghazali: Saint or Subversive?” Die Welt des Islam, 34 (1): 1-20.

Early, Evelyn Aleene. 1981. "Bahithat al-Badiya: Cairo Viewed from the Fayyum Oasis." Journal of Near Eastern Studies. Vol. 40: 339-341.

Egyptian Constitution. 1971. Cairo, Egypt: Al Matba' al Amiriya.

El-Baradei, M. 1996. The Educational Status of Women in Egypt. Cairo, Egypt: Friedrich Ebert Stiftung.

El-Hamamsy, Laila. 1994. Early Marriage and Reproduction in Two Egyptian Villages. Cairo, Egypt: The Population Council and UNFPA.

El-Kholy. Interview conducted by Nadia Wassef on 17 October, 1997.

Elsadda, Huda. Interview conducted by Nadia Wassef on 15 October, 1997.

Elsadda, Huda. 1998 a. Al-Namazeg al-Namateya l'il-Mar'ah fi al-E'lam. (Stereotypes of Women in the Media). Hagar: Kitab al-mar'ah 5 and 6: 45-56.

Elsadda, Huda. 1998b. “Introduction." Zaman al-Nisa' wa'l dhakira al-badeela (Women's Time and Alternate Memory) (pp. 1-12). Cairo, Egypt: Women and Memory Forum.

El-Safty, Madiha. 1995. El Emala El Nisaeya (Female Employment: A Sociological Profile). Cairo, Egypt: Friedrich Ebert Stiftung.

El-Sayed, M and K. El Menoufi eds. 1996. Haqiqat Al Ta'adodeya Al Siyasseya Fi Masr (The Reality of Political Pluralism in Egypt). Ed. M. El Sayed and K. El Menoufi. Cairo, Egypt: Madbouli Publishing House, 1996. 
El-Tawila, Sahar, Omaima El-Gibaly, Barbara Ibrahim, Fikrat El-Sahr, Sunny Sallam, Susan Lee, Barbara Mensh, Hind Wassef, Sarah Bukhari, and Osman Galal. 1999 Translitions to Adulthood: A National Survey of Adolescents in Egypt. The Population Council.

Farah, Nadia Ramsis. 1997. Child Labour in Egypt within the Context of the Convention on the Rights of the Child. Paper presented to UNICEF Egypt.

Fawwaz, Zaynab. n.d. Al-Durr al-Manthur fi Tabaquat Rabat al-Khudur. Kuwait: Maktabat ibn Kotayba.

Fernea, Elizabeth Warnock. 1998. In Search Of Islamic Feminism: One Woman's Global Journey. New York, NY [USA]: Doubleday.

FGM Task Force. 1997. “Position Paper.”

Gomaa, Salwa. 1996. "Al-Mosharaka al-Siyassiya l'il-Mar'ah" (The Political Participation of Women). Hagar: Kitab al-mar'ah 3 and 4.

Guenena, Nemat. 1986. The Jihad: An Islamic Alternative in Egypt. Cairo Papers in Social Sciences. Cairo, Egypt: American University in Cairo Press.

El-Guindi, Fadwa, cited in Leila Ahmed. 1993. Women and Gender in Islam. Cairo, Egypt: American University in Cairo Press, p. 210.

Halpern, M. 1963. The Politics of Social Change in the Middle East and North Africa. Princeton, NJ [USA]: Princeton University Press.

Hanafi, Hassan. 1982 (Spring). "The Relevance of the Islamic Alternative in Egypt." Arab Studies Quarterly. Vol. 4. No. 1 and $2: 62-63$.

Hatem, Mervat. 1986 (Spring). “The Enduring Alliance of Nationalism and Patriarchy in Muslim Personal Status Laws: The Case of Modern Egypt." Feminist Issues 6(1): 19-43.

Hatem, Mervat. 1993. "Toward the Development of Post-Islamist and Post-Nationalist Feminist Discourses in the Middle East." In Judith Tucker (Ed.), Arab Women: Old Boundaries New Frontiers (pp. 29-48). Bloomington, IN [USA]: Indiana University Press.

Hill, Enid. 1979. Mahkama! Studies in the Egyptian Legal System. London, UK: Ithaca Press.

Hoffman, Valerie J. 1985. “An Islamic Activist: Zaynab al-Ghazali.” In Elizabeth Fernea (Ed.), Women and the Family in the Middle East: New Voices of Change (pp. 233-254). Austin, TX [USA]: University of Texas Press. 
Hoffman-Ladd, Valerie J. 1987. "Polemics on the Modesty and Segregation of Women in Contemporary Egypt." International Journal of Middle Eastern Studies. Vol. 19: 23-50.

Hosni, Mounira. n.d. Ayyam fi al-hay'at al-nisa'iyya (Days in Women's Organizations). Cairo, Egypt: Matba' at al-Miligi

Humm, Maggie. 1990. The Dictionary of Feminist Theory. Columbus, OH [USA]: University of Ohio Press.

Hussein, Aziza. 1985. "Recent Amendments to Egypt's Personal Status Laws." In Elizabeth Warnock Fernea (Ed.), Women and the Family in the Middle East: New Voices of Change (pp. 229232). Austin, TX [USA]: University of Texas Press.

Ibrahim, Saad Eddin. 1982. "Islamic Militaricy as a Social Movement: The case of Two Groups in Egypt". In Ali Hilal Dessouki (Ed.) Islamic in the Arab World. NY, USA: Praeger Publishers: (pp. 117-136)

Ibrahim, Saad Eddin. 1996. Egyptian Law 32 on Egypt's Private Sector Organizations: A Critical Assessement. Cairo, Egypt: Ibn Khaldoun Center For Development Studies, Working Papers, No.3.

Kabeer, N. 1994. Reversed Realities: Gender Hierarchies in Development Thought. London, UK: Verso: (chapters 1-4).

Kamal, Ihsan. 1985. “A Jailhouse of My Own.” In Mahmoud Manzalaoui (Ed.), Arabic Short Stories 1945-1965. Cairo, Egypt: American University in Cairo Press:304-316.

Kandil, Amani. 1995. Civil Society in the Arab World: Private Voluntary Organizations. Washington DC: Civicus; The World Alliance for Citizen Participation. pp. 40-44.[SML36]

Kandiyoti, Deniz. 1991a. "Introduction." Women, Islam, and the State (pp. 1-21). London, UK: Macmillan.

Kandiyoti, Deniz. 1991b. "Islam and Patriarchy: A Comparative Perspective." Women in Middle Eastern History: Shifting Boundaries in Sex and Gender. Nikki R. Keddie and Beth Baron. (Eds.). New Haven: Yale University Press, 1991.

Kandiyoti, Deniz. 1996. Gendering the Middle East. Syracuse, NY [USA]: Syracuse University Press.

Karam, Azza. 1998. Women, Islamisms, and the State: Contemporary Feminisms in Egypt. London, UK: Macmillan.

Khater, Akram, and Cynthia Nelson. 1988. "Al-Harakah Al-Nissa'iyah: The Women's Movement and Political Participation in Modern Egypt." Women's Studies International Forum. Vol. 2(5): 465-483. 
Khattab, Hind. 1992. The Silent Endurance: Social Conditions of Women's Reproductive Health in Rural Egypt. Cairo, Egypt: UNICEF and The Population Council:171-183.

Latowski[SML37], Robert. 1995. Egypt PVO Sector Study.

Macleod, Arlene Elowe. 1991. Accommodating Protest: Working Women, the New Veiling, and Change in Cairo. New York, NY [USA]: Columbia University Press.

Marsot, Afaf Lutfi al-Sayyid. 1985. A Short History of Modern Egypt. Cambridge, UK: Cambridge University Press.

Marsot, Afaf Lutfi al-Sayyid. 1995. Women and Men in Late Eighteenth-Century Egypt. Austin, TX [USA]: University of Texas Press.

Minces, Juliette. 1982. The House of Obedience: Women in Arab Society. London, UK: Zed Books.

Musa, Nabawiya. 1920. Al-Mar'ah wa al-'amal (Women and Work). Alexandria, Egypt: al-Matba'a al-Qawmia.

Musa, Salama. 1961. The Education of Salama Musa. Trans. L. O. Schuman. Leiden, The Netherlands: E. J. Brill.

Nassar, Heba. 1996a. Analysis of the Survey of the Main Interventions Enhancing the Socioeconomic Status of Women in Egypt. Cairo, Egypt: Friedrich Ebert Stiftung.

Nassar, Heba. 1996b. Awda' El-Mara' Fi Souk El-Amal El-Masri (The Employment Status of Women In Egypt) Cairo, Egypt: Friedrich Ebert Stiftung.

Nassef, Majdeddin Hifni. 1924. "Mu'assissit al-Nahda al-Nasawiya bi-Misr: Malak Hifni Nassef (Bahithat al-Badiya). (The Founder of the Women's Renassance in Egypt)." In Fathia Mohamed (Ed), Balaghat al Nisa'a fi al-Karn al-'Ishreen (The Eloquence of Women in the Twentieth Century) (pp 3-60). Cairo, Egypt: al-Maktaba al-Masriya.

Nassef, Malak Hifni. 1910. "Al-Hijab am al-Sufur" (Veiling or Unveiling). Al-Nisa'iyat (Woman's Pieces). Cairo, Egypt: Matba'at al Taqadom.

National NGO Committee. 1994. Egyptian NGO Platform Document to the International Conference on Population and Development. Cairo, Egypt: Matba'at al-Geel.

National Proverbs: Arabia. 1913. London, UK: Frank Palmer.

Nawar, Leila. 1994. Quality of Care in Reproductive Health Services. Cairo, Egypt: CAPMAS and The Population Council. 
Nelson, Cynthia. 1984. “Islamic Tradition and Women's Education: The Egyptian Experience." In Sandra Hocker et al. (Eds.), The World Yearbook of Education: Women and Education (pp. 211-226). New York, NY [USA]: Nicolar Publishing.

Nelson, Cynthia. 1996. Doria Shafik, Egyptian Feminist: A Woman Apart. Cairo, Egypt: American University in Cairo Press.

Philipp, Thomas. 1978. "Feminism and Nationalist Politics in Egypt." In Lois Beck and Nikki Keddie (Eds.), Women in the Muslim World (pp. 277-294). Cambridge, MA [USA]: Harvard University Press.

Raouf, Heba. 1994 (November-December). “Western Feminism is Not What We Need.” MERIP: 27.

Russell, Thomas. 1949. Egyptian Service. London, UK: Murray.

Shaarawi, Huda. 1977. "Huda Shaarawi, Founder of the Egyptian Women's Movement." In Elizabeth Warnock Fernea and Basima Qattan Bezirgan (Eds.), Middle Eastern Muslim Women Speak (pp. 193-200). Austin, TX [USA]: University of Texas Press.

Shaarawi, Huda. 1981. Mudhakkirat Ra'idat al-Mar'ah al-'Arabiyah al-Hadithah: Huda Shaarawi (Memoirs of the Leader of the Modern Arab Woman). Cairo, Egypt: Dar al-Hilal.

Shamir, Shimon. 1992. Islam, Politics, and Regimes in Islam and Democracy. In Timothy D.Sisk (Ed.) Perspective Series. Washington, DC [USA]: United States Institute Of Peace.

Shukrallah, Hala. 1994 (Summer). "The Impact of the Islamic Movement in Egypt." Feminist Review 47: 15-32.

Shukrallah, Hala. 1997. Gender Policy Planning: Working with Women and Men in Micro-Enterprise And Community Development in Egypt. The Processes of Integrating Gender in Egyptian Institutions: Three Case Studies. London, UK: University of London, Department Planning Unit.

Shukrallah, Hala. Interview conducted by Nadia Wassef, 27 April, 1998.

Shukrallah, Hala. Interview conducted by Nadia Wassef, November, 1998.

Singerman, Diane. 1997. Avenues of Participation: Family, Politics, and Networks in Urban Quarters of Cairo. Cairo, Egypt: American University in Cairo Press.

Soliman, Azza. Interview conducted by Nadia Wassef, 14 October 1997

Soueif, Ahdaf. 1983. “The Wedding of Zeina.” Aisha. London, UK: Jonathan Cape. 
Stowasser, Barbara F. 1993. “Women's Issues in Modern Islamic Thought.” In Judith E. Tucke (Ed.), Arab Women: Old Boundaries, New Frontiers (pp. 3-28). Bloomington, IN [USA]: University of Indiana Press.

Sullivan, D[SML39]. 1994. Private Voluntary Organizations in Egypt. Gainesville, FL [USA]: University of Florida Press.

Talhami, Ghada. 1996. The Mobilization of Muslim Women in Egypt. Gainesville, FL [USA]: University of Florida Press.

Tucker, Judith. 1985. Women in Nineteenth-Century Egypt. Cambridge University Press.

Wassef, Hind. 1996. "Constructions of Gender in Middle and Secondary School Curriculum in Egypt." Arab Regional Population Conference Proceedings, vol. 2: 324-352.

Wassef, Hind. Interview conducted by Nadia Wassef on 12 May, 1998.

Wassef, Nadia. 1997 (26 June-9 July). “Constitutional Discrimination." Cairo Times, 1(9): 8-9.

Wassef, Nadia. 1998 (December). Da Min Zaman: Munadharat al-Mady wa'l-Hadir Hawl al-Tashweeh al-Ginsy lil-Inath fi Misr (Past and Present Discourse on FGM in Egypt). Cairo, Egypt: Friedrich Ebert Stiftung.

Woolf, Virginia. 1987. A Room of One's Own. London, UK: Grafton. First edition, 1928.

Yadlin, Rivka. 1995. “The Seeming Duality: Patterns of Interpersonal Relations in a Changing Environment." In Shimon Shamir (Ed.), Egypt From Monarchy to Republic: A Reassessment of Revolution and Change (pp 151-172). Boulder, CO [USA]: Westview Press.

Zayat, Latifa. 1996. The Search: Personal Papers. Trans. Sophie Bennett. London, UK: Quartet.

El-Zanaty, Fatma H.; EM Hussein; GA Shawky; AK Way; and S. Kishor. 1996. Egypt Demographic and Health Survey 1995. Calverton, MD [USA]: National Population Council [Egypt] and Macro International Inc.

Zubaida, Sami. 1993. Islam, The People, and The State. London, UK: I.B. Tauris.

Zulfikar, Mona. n.d. The Egyptian Woman in a Changing World. The New Civic Forum. Cairo, Egypt: The Wahba Press.

Zulfikar, Mona. 1995. Women in Development: A Legal Study. Cairo: UNICEF.

Zurayk, H. Women's Reproductive Health in the Arab World. Cairo, Egypt: The Population Council Regional Papers no. 39, 1994. 
$99^{2}$
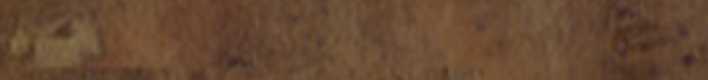

Be:

\section{Population Council}

West Asia and North Africa Regional Office

Cairo 12211 Dokki, Egypt.

Tel:(202) 570-1733 Fax:(202) 570-1804 